\title{
Identification of gp120 Residue His105 as a Novel Target for HIV-1 Neutralization by Small-Molecule CD4-Mimics
}

Christopher J. Fritschi, ${ }^{+\pi} \quad$ Shuaiyi Liang, ${ }^{\ddagger \pi}$ Mohammadjavad Mohammadi," Saumya Anang, ${ }^{\perp}$ Francesca Moraca," Junhua Chen, ${ }^{\dagger}$ Navid Madani, ${ }^{\perp}$ Joseph G. Sodroski, ${ }^{\perp}, \nabla, \nabla$ Cameron F. Abrams," Wayne A. Hendrickson,,$^{\ddagger, \S^{*}}$ and Amos B. Smith, III ${ }^{+*}$

† Department of Chemistry, University of Pennsylvania, Philadelphia, Pennsylvania 19104, United States

$\ddagger$ Department of Biochemistry and Molecular Biophysics and $\S$ Department of Physiology and Cellular Biophysics, Columbia University, New York, New York 10032, United States

॥ Department of Chemical and Biological Engineering, Drexel University, Philadelphia, Pennsylvania 19104, United States

$\perp$ Department of Cancer Immunology and Virology, Dana-Farber Cancer Institute and \# Department of Microbiology, Harvard Medical School, Boston, Massachusetts 02115, United States

$\nabla$ Department of Immunology and Infectious Diseases, Harvard School of Public Health, Boston, Massachusetts 02115, United States

\section{Supporting Information}

Summary of Crystallographic Data......................................................................... S2

Experimental Methods.................................................................................................. S3

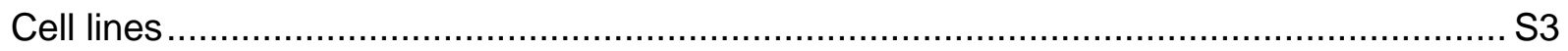

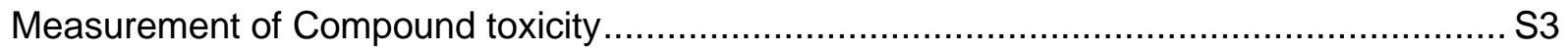

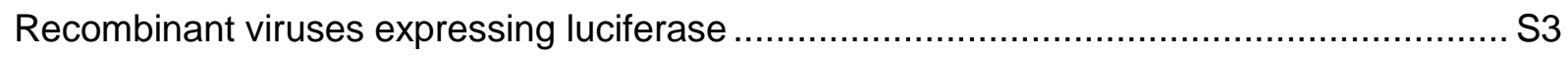

Infection by single-round luciferase viruses ........................................................... 44

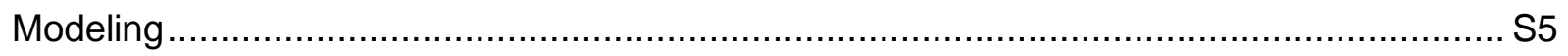

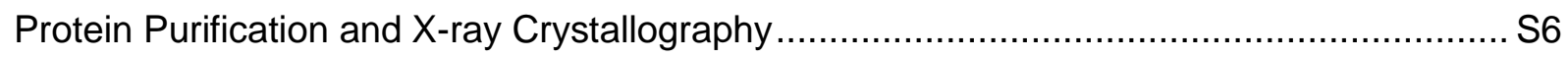

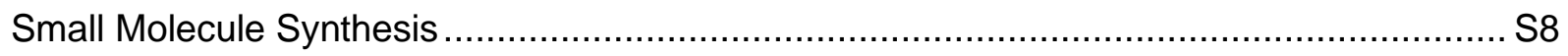




\section{Summary of Crystallographic Data}

\section{Table S1-Summary of Crystallographic Data}

Diffraction Data Statistics

\begin{tabular}{|c|c|c|c|}
\hline Dataset & CJF-II-204 (14) & CJF-III-049-S (16) & CJF-III-049-R (17) \\
\hline Beamline & APS 24-ID-C & APS 24-ID-E & APS 24-ID-E \\
\hline$(\AA)$ & 0.9792 & 0.9792 & 0.9792 \\
\hline Space group & $\mathrm{P} 22_{1} 2_{1}$ & $\mathrm{P} 22_{2} 2_{1}$ & $\mathrm{P} 2{ }_{1}{ }_{1}{ }_{2}$ \\
\hline \multirow[t]{2}{*}{ Unit cell dimension $(\AA)$} & 72.19121 .05 & 71.81120 .66 & 71.58120 .75 \\
\hline & 195.62 & 195.25 & 195.28 \\
\hline $\mathrm{Z}_{\mathrm{a}}^{\mathrm{a}}$ & 4 & 4 & 4 \\
\hline Bragg spacings $(\AA)^{b}$ & $\begin{array}{c}48.90-2.80(2.91- \\
2.80)\end{array}$ & $\begin{array}{c}48.81-2.75(2.85- \\
2.75)\end{array}$ & $\begin{array}{c}48.82-2.70(2.79- \\
2.70)\end{array}$ \\
\hline Total reflections & 279481 & 295051 & 314373 \\
\hline Unique reflections & 43050 & 44923 & 47367 \\
\hline Completeness (\%) & 99.4 & 99.8 & 99.9 \\
\hline $\mathrm{CC}_{1 / 2}(\%)^{\mathrm{C}}$ & $99.9(45.7)$ & $99.5(80.2)$ & $99.8(77.6)$ \\
\hline$</ / \sigma(I)>d$ & $12.5(2.5)$ & $10.5(2.1)$ & $11.6(1.8)$ \\
\hline Rmerge $^{e}$ & $0.176(1.53)$ & $0.159(0.999)$ & $0.113(1.279)$ \\
\hline Rmeas $^{\dagger}$ & $0.210(1.801)$ & $0.188(1.188)$ & $0.155(1.516)$ \\
\hline Rwork ${ }^{g}$ & 0.230 & 0.244 & 0.235 \\
\hline Rfree $^{h}$ & 0.299 & 0.284 & 0.279 \\
\hline $\begin{array}{l}\text { RMS bond } \\
\text { deviation }(\AA)\end{array}$ & 0.019 & 0.005 & 0.003 \\
\hline $\begin{array}{l}\text { RMS angle deviation } \\
\left({ }^{\circ}\right)\end{array}$ & 1.28 & 1.01 & 0.96 \\
\hline Average B factor $\left(\AA^{2}\right)$ & 61.2 & 65.4 & 71.6 \\
\hline $\begin{array}{l}\text { Ramachandran } \\
\text { analysis } \\
\text { favored/allowed (\%) }\end{array}$ & $94.1 / 0.8$ & $93.7 / 1.5$ & $92.2 / 1.7$ \\
\hline PDB code & & & \\
\hline
\end{tabular}

${ }^{a} Z_{a}$ stands for number of subunits per asymmetric unit.

$\mathrm{b}$ Values in the outermost shell are given in parentheses.

${ }^{\mathrm{C}} \mathrm{CC}_{12}$ is the correlation coefficient of integrated intensities between randomly split two half data sets

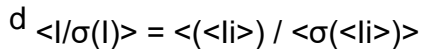

e $R_{\text {merge }}=(\Sigma|l i-<| i>\mid) / \Sigma|l i|$, where li is the integrated intensity of a given reflection.

$f R_{\text {meas }}$ is the redundancy-independent merging $R$ factor (50).

$g R_{\text {work }}=(\Sigma|| \mathrm{Fo}|-| \mathrm{Fc}||) / \Sigma|\mathrm{Fo}|$, where $\mathrm{Fo}$ and Fc denote observed and calculated structure factors, respectively.

h R free was calculated using $5 \%$ of data excluded from refinement. 


\section{Experimental Methods}

\section{Cell lines}

293T human embryonic kidney (HEK) cells, COS-1 African green monkey kidney fibroblasts, HOS human osteosarcoma cells, and Cf2Th canine thymocytes (American Type Culture Collection) will be used at $37^{\circ} \mathrm{C}$ and $5 \% \mathrm{CO}_{2}$ in DMEM with $10 \%$ fetal bovine serum (FBS; Sigma) and $100 \mathrm{ug} / \mathrm{ml}$ of penicillin-streptomycin (Mediatech, Inc.). Cf2Th cells stably expressing human CD4-CCR5, CCR5, or CD4-CXCR4 will be grown in medium supplemented with 200 $\mathrm{ug} / \mathrm{ml}$ hygromycin (Roche Diagnostics) and $400 \mathrm{ug} / \mathrm{ml} \mathrm{G418} \mathrm{(Invitrogen).}$

\section{Measurement of Compound toxicity}

The effect of a 48-h incubation with each compound on the viability of Cf2Th-CD4/CCR5 cells will be evaluated using the MTT [3-(4,5-dimethylthiazol-2-yl)-2,5-diphenyltetrazolium bromide] assay. ${ }^{1}$ Approximately $1.5 \times 10^{4}$ cells will be plated in each well of a 96-well plate. The DMSO control or various concentrations of compounds will be added to duplicate wells. Additional control wells will be prepared without cells. The plates will be incubated for $48 \mathrm{~h}$ at $37^{\circ} \mathrm{C}$ in $5 \%$ $\mathrm{CO}_{2}$, after which, $1 / 5$ volume of the assay solution (Abcam) will be added to each well. The plates will be incubated for an additional $3 \mathrm{~h}$ at $37^{\circ} \mathrm{C}$ and $5 \% \mathrm{CO}_{2}$. The absorbances at $570 \mathrm{~nm}$ and $605 \mathrm{~nm}$ will be measured. $R$ represents the ratio of the absorbance at $570 \mathrm{~nm}$ to that at $605 \mathrm{~nm}$. The cell viability will be calculated by ( $R_{\text {sample }}-R_{\text {no cells }}$ / (RDMSO $-R_{\text {no }}$ cells) $x$ 100.

\section{Recombinant viruses expressing luciferase}

293T HEK cells will be cotransfected with plasmids expressing the pCMV $\Delta \mathrm{P} 1 \Delta$ env HIV-1 GagPol packaging construct, the HIV-1 Envs or control envelope glycoproteins from amphotropic murine leukemia virus (AMLV), human T-lymphotropic virus-1 (HTLV-1), simian immunodeficiency virus (SIV $\mathrm{mac}_{239}$ ), and human immunodeficiency virus-2 (HIV-2UC1), and the firefly luciferase-expressing vector at a DNA ratio of 1:1:3 ug using the Effectene transfection reagent (Qiagen). ${ }^{2}$ The plasmids expressing the HIV-1 Envs and Rev protein will be based on pSVIllenv. ${ }^{2}$ Cotransfection produced recombinant luciferase-expressing viruses capable of a single round of infection. The virus-containing supernatants will be harvested between 36 and $40 \mathrm{~h}$ after transfection, cleared of debris by low-speed centrifugation, aliquoted, and frozen at $-80^{\circ} \mathrm{C}$ until further use. The reverse transcriptase (RT) levels of all viruses will be measured as previously described. ${ }^{3}$

\footnotetext{
${ }^{1}$ Madani, N.; Princiotto, A. M.; Schön, A.; LaLonde, J.; Feng, Y.; Freire, E.; Park, J.; Courter, J. R.; Jones, D. M.; Robinson, J.; Liao, H. X.; Moody, M. A.; Permar, S.; Haynes, B.; Smith, A. B., 3rd; Wyatt, R.; Sodroski, J., CD4-mimetic small molecules sensitize human immunodeficiency virus to vaccine-elicited antibodies. J Virol 2014, 88 (12), 6542-55.

${ }^{2}$ van Meerloo, J.; Kaspers, G. J.; Cloos, J., Cell sensitivity assays: the MTT assay. Methods in molecular biology (Clifton, N.J.) 2011, 731, 237-45.

${ }^{3}$ Rho, H. M.; Poiesz, B.; Ruscetti, F. W.; Gallo, R. C., Characterization of the reverse transcriptase from a new retrovirus (HTLV) produced by a human cutaneous T-cell lymphoma cell line. Virology 1981, 112 (1), 355-60.
} 


\section{Infection by single-round luciferase viruses}

Cf2Th-CD4/CCR5, Cf2Th-CCR5, or Cf2Th-CD4/CXCR4 target cells will be seeded at a density of $6 \times 10^{3}$ cells/well in 96-well luminometer-compatible tissue culture plates (PerkinElmer) $24 \mathrm{~h}$ before infection. On the day of infection, increasing concentrations of different compounds will be incubated with recombinant viruses at $37^{\circ} \mathrm{C}$ for $30 \mathrm{~min}$. In the case of washout assays, increasing concentrations of compound will be incubated with recombinant viruses at $37^{\circ} \mathrm{C}$ for $30 \mathrm{~min}$; the virus will be pelleted by centrifugation at $21,000 \times \mathrm{g}$ for 15 to $30 \mathrm{~min}$ at room temperature, the supernatant will be discarded, and the virus pellet will be washed once with medium before resuspension in medium. In the case of sensitization assays, a constant concentration of compound will be incubated with virus at $37^{\circ} \mathrm{C}$ for $30 \mathrm{~min}$; then, increasing concentrations of antibody were added to the virus-compound mixture and incubated at $37^{\circ} \mathrm{C}$ for an additional $30 \mathrm{~min}$. In all the above-described cases, the mixtures are then added to the target cells. At this point, in assays involving Cf2Th-CCR5 target cells or recombinant viruses with poor entry ( $x 105$ relative light units [RLU]/20ul), the virus-compound mixtures are spinoculated onto target cells by centrifugation at $1,800 \mathrm{rpm}$ for $30 \mathrm{~min}$ at $21^{\circ} \mathrm{C} .{ }^{4}$ In all cases, the viruscompound-target cell mixtures will be diluted 1:4 in medium and incubated for 48 to $72 \mathrm{~h}$ at $37^{\circ} \mathrm{C}$; after this time, the medium is removed from each well and the cells are lysed by the addition of $30 \mathrm{ul}$ of passive lysis buffer (Promega) and three freeze-thaw cycles. An EG\&G Berthold LB 96V microplate luminometer is used to measure the luciferase activity of each well

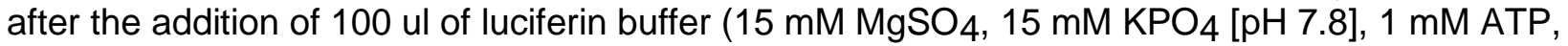
and $1 \mathrm{mM}$ dithiothreitol) and $50 \mathrm{ul}$ of $1 \mathrm{mM}$ firefly D-luciferin free acid, 99\% (Prolume).

${ }^{4}$ O'Doherty, U.; Swiggard, W. J.; Malim, M. H., Human immunodeficiency virus type 1 spinoculation enhances infection through virus binding. $J$ Virol 2000, 74 (21), 10074-80. 


\section{Modeling}

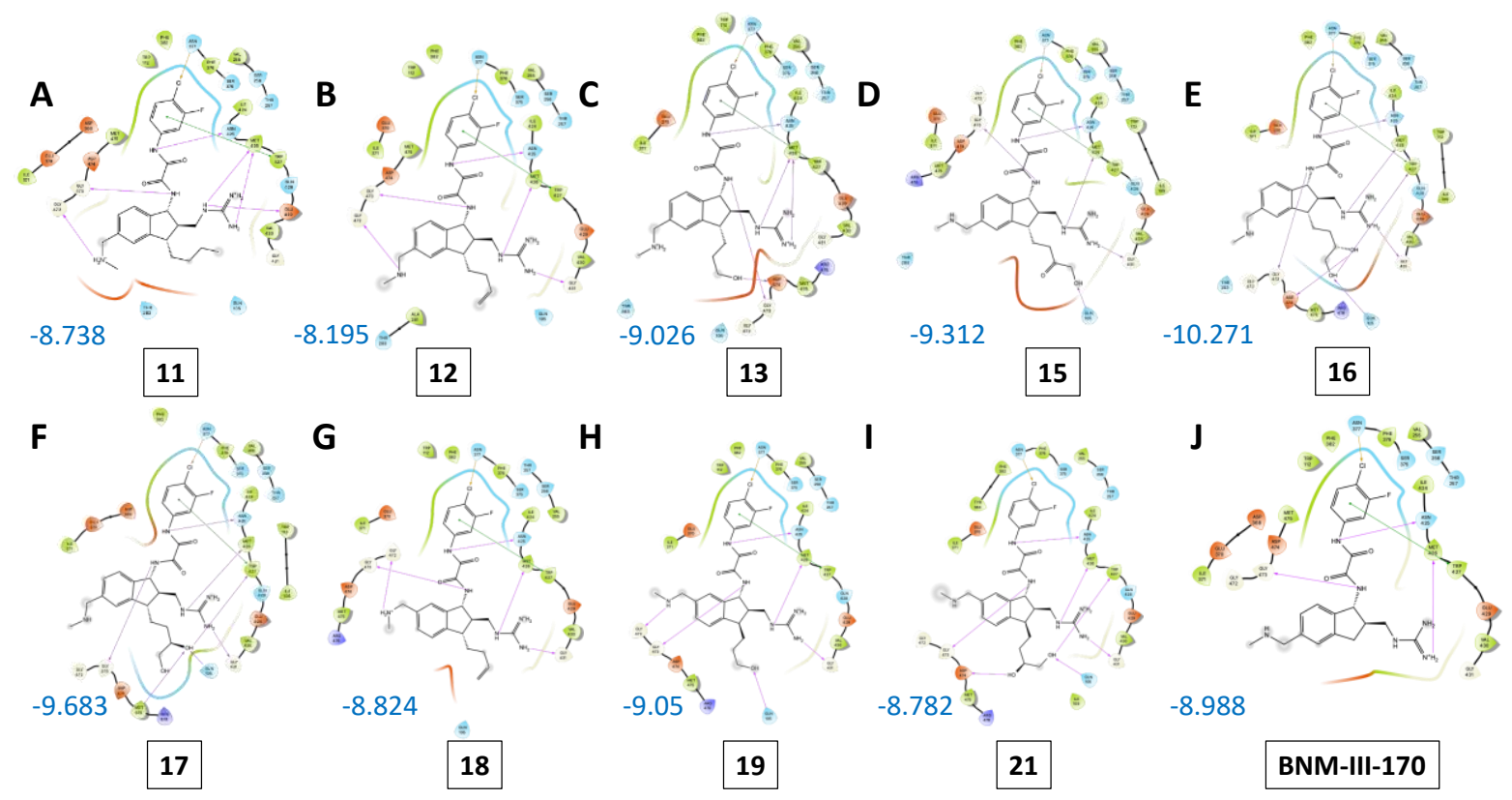

Figure S1 2D representation of ligand interaction for 11-13, 15-19, 21, and BNM-III-170 (A-J) docked in JR-FL Phe43 pocket. The values of GlideScore are shown in blue $(\mathrm{kcal} / \mathrm{mol})$. The gp120 residues are colored as follows: green, nonpolar; blue, polar; indigo, basic; red, acidic.

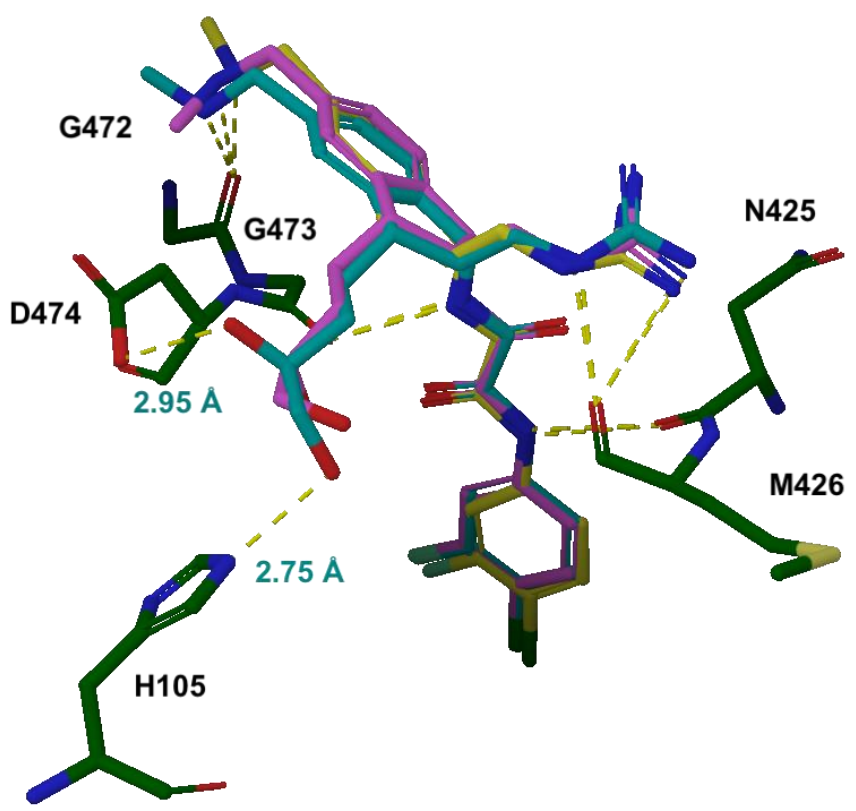

Figure S2 Superimposition of the crystal structure of BNM-III-170 (yellow) and the docking pose of 16 (cyan - R) and 17 (purple - S) in C1086 Phe43 pocket of gp120 core monomer. 
The target structures were taken from core monomer JR-FL gp120 (PDB ID: 2B4C) ${ }^{5}$ and C1086 gp120 (PDB ID: 5F4P) ${ }^{6}$ prepared using Protein Preparation Wizard at default settings and energy-minimized using GPU-accelerated Desmond software (Schrödinger Inc., 2020) ${ }^{7-11}$. The pretreated gp120 core monomer was used as receptor for the subsequent docking calculation of 11-13, 15-19, 21, and BNM-III-170. Docking performed using Glide ${ }^{12-14}$ with the standard precision (SP) scoring function and the number of output poses was increased to $50^{15}$. The oxalamide torsional angle was restrained to $180^{\circ}$ to keep the carbonyl groups in dipoleminimizing trans conformation.

\section{Protein Purification and X-ray Crystallography}

A plasmid of gp120 Clade C1086 was donated by Lei Chen from Peter Kwong's laboratory (National Institute of Health). 600ug plasmid was transfected into $1 \mathrm{~L} \mathrm{HEK293} \mathrm{GnTI-} \mathrm{suspension}$ cells and expressed into the supernatant. The supernatant was dripped through the 17bconjugated Protein A column and was washed with $100 \mathrm{ml} 1 \mathrm{x}$ PBS. The gp120 bound to the conjugated $17 \mathrm{~b}$ resin was eluted with IgG elution buffer (Pierce). The gp120 was deglycosylated overnight in a $37^{\circ} \mathrm{C}$ water bath with endoglycosidase $\mathrm{H}$ and purified with a Con-A column and a Superdex 200 column (GE Healthcare). The purified deglycosylated gp120 was concentrated to $10 \mathrm{mg} / \mathrm{ml}$.

Crystallization of unliganded gp120 Clade C1086 was performed at $290 \mathrm{~K}$ using the hanging drop vapor diffusion method. The crystals grew in drops consisting of $1 \mu \mathrm{L}$ of protein and $1 \mu \mathrm{L}$ of reservoir solution against $300 \mu \mathrm{L}$ of reservoir solution 23\% (w/v) PEG 1500, 0.1 M CaCl2, $0.1 \mathrm{M}$ imidazole $\mathrm{pH}$ 6.5. For each experiment, the compound of interest was dissolved in $100 \%$ DMSO. Single crystals were picked from the mother liquor and soaked in $2 \mu \mathrm{L}$ of a stabilization buffer that contained 26\% PEG 1500 (w/v), $0.1 \mathrm{M} \mathrm{CaCl2,} 0.1 \mathrm{M}$ imidazole pH 6.5, $2.5 \mathrm{mM}$ Tris$\mathrm{HCl} \mathrm{pH} \mathrm{7.5,} 350 \mathrm{mM} \mathrm{NaCl}, 0.02 \% \mathrm{NaN3}, 5 \%(\mathrm{v} / \mathrm{v}) \mathrm{DMSO}$ and $200 \mathrm{M}$ of the compound. The clade C1086 gp120 crystals were soaked for $30 \mathrm{~min}$ in the stabilization buffer, and then

5 Huang, C.-c.; Tang, M.; Zhang, M.-Y.; Majeed, S.; Montabana, E.; Stanfield, R. L.; Dimitrov, D. S.; Korber, B.; Sodroski, J.; Wilson, I. A.; Wyatt, R.; Kwong, P. D., Structure of a V3-Containing HIV-1 gp120 Core. Science 2005, 310 (5750), 1025.

6 Melillo, B.; Liang, S.; Park, J.; Schön, A.; Courter, J. R.; LaLonde, J. M.; Wendler, D. J.; Princiotto, A. M.; Seaman, M. S.; Freire, E.; Sodroski, J.; Madani, N.; Hendrickson, W. A.; Smith, A. B., Small-Molecule CD4-Mimics: Structure-Based Optimization of HIV-1 Entry Inhibition. ACS Medicinal Chemistry Letters 2016, 7 (3), $330-334$.

7 Maestro, version 12.6; Schrödinger, LLC, New York, NY, 2020.

8 Epike, version 5.4; Schrödinger, LLC, New York, NY, 2020.

9 Prime; Schrödinger, LLC, New York, NY, 2020.

10 Desmond; version 6.4; Schrödinger, LLC, New York, NY, 2020.

11 Bowers, Kevin J., et al., Scalable algorithms for molecular dynamics simulations on on commodity clusters. ACM/IEEE CS 2006 Conf. 2006, 43-43.

12 Glide, version 8.9; Schrödinger, LLC, New York, NY, 2020.

13 Halgren, Thomas A., et al., Glide: a new approach for rapid, accurate docking and scoring. 2. Enrichment factors in database screening. J. Med. Chem. 47.7 (2004): 1750-1759.

14 Friesner, Richard A., et al., Glide: a new approach for rapid, accurate docking and scoring. 1. Method and assessment of docking accuracy. J. Med. Chem. 47.7 (2004): 1739-1749.

15 Zou, Shitao, et al., Long-acting BMS-378806 analogues stabilize the state-1 conformation of the human immunodeficiency virus type 1 envelope glycoproteins. J. Virol. 94.10 (2020): e00148-20. 
transferred for 5 seconds into cryo-protectant, composed from the stabilization buffer but with $30 \%$ ethylene glycol.

Diffraction data for were collected at the NE-CAT beamlines of the Advanced Photon Source at Argonne National Laboratory. Crystals of clade C1086 with CJF-II-204 (14) used the 24ID-C beamline while those for CJF-III-049-S (16) and CJF-III-049-R (17) used 24ID-E. Although previous crystals of complexes of CD4 mimetic compounds with C1086 gp120 were in a C222 1 lattice, these crystals proved to be in space group $\mathrm{P} 2{ }_{1} 2_{1} 2_{1}$ with four copies in the asymmetric unit. The crystal structures were solved by the molecular replacement module in PHENIX using unliganded clade C1086 (PDB ID: 3TGR).

Table S2 -- Complete hydrogen bond distances between compounds and gp120 Clade C1086

\begin{tabular}{|c|c|c|c|c|}
\hline \multicolumn{2}{|r|}{ Compoound } & \multicolumn{2}{|c|}{$\begin{array}{c}\text { gp120 Clade } \\
\text { C1086 }\end{array}$} & \multirow[t]{2}{*}{$\begin{array}{c}\text { Distances } \\
(\AA ̊)\end{array}$} \\
\hline Name & Atom & $\begin{array}{c}\text { Residu } \\
\mathrm{e}\end{array}$ & Atom & \\
\hline \multirow{5}{*}{16} & Butanediol primary $\mathrm{OH}$ (chain A) & $\mathrm{H} 105$ & $\mathrm{~N}_{\varepsilon}$ & 2.99 \\
\hline & Butanediol primary $\mathrm{OH}$ (chain $\mathrm{B}$ ) & H105 & $\mathrm{N}_{\varepsilon}$ & 3.00 \\
\hline & Butanediol primary $\mathrm{OH}$ (chain $\mathrm{C}$ ) & H105 & $\mathrm{N}_{\varepsilon}$ & 3.00 \\
\hline & Butanediol primary $\mathrm{OH}$ (chain D) & H105 & $\mathrm{N}_{\varepsilon}$ & 3.01 \\
\hline & $\begin{array}{l}\text { Average } \\
\end{array}$ & H105 & $\mathbf{N}_{\varepsilon}$ & 3.00 \\
\hline \multirow{5}{*}{16} & Butanediol secondary $\mathrm{OH}$ (chain A) & D474 & $\mathrm{O}_{1}$ & 3.12 \\
\hline & Butanediol secondary $\mathrm{OH}$ (chain $\mathrm{B}$ ) & D474 & $\mathrm{O}_{1}$ & 2.98 \\
\hline & Butanediol secondary $\mathrm{OH}$ (chain $\mathrm{C}$ ) & D474 & $\mathrm{O}_{1}$ & 3.05 \\
\hline & Butanediol secondary $\mathrm{OH}$ (chain D) & D474 & $\mathrm{O}_{1}$ & 3.02 \\
\hline & Average & D474 & $\mathbf{O}_{1}$ & 3.04 \\
\hline \multirow{5}{*}{17} & Butanediol primary $\mathrm{OH}$ (chain A) & H105 & $\mathrm{N}_{\varepsilon}$ & 3.20 \\
\hline & Butanediol primary $\mathrm{OH}$ (chain $\mathrm{B}$ ) & $\mathrm{H} 105$ & $\mathrm{~N}_{\varepsilon}$ & 3.13 \\
\hline & Butanediol primary $\mathrm{OH}$ (chain $\mathrm{C}$ ) & $\mathrm{H} 105$ & $\mathrm{~N}_{\varepsilon}$ & 3.15 \\
\hline & Butanediol primary $\mathrm{OH}$ (chain D) & $\mathrm{H} 105$ & $\mathrm{~N}_{\varepsilon}$ & 3.05 \\
\hline & Average & H105 & $\mathbf{N}_{\varepsilon}$ & 3.13 \\
\hline \multirow{5}{*}{17} & Butanediol secondary $\mathrm{OH}$ (chain A) & D474 & $\mathrm{O}_{1}$ & 2.85 \\
\hline & Butanediol secondary $\mathrm{OH}$ (chain $\mathrm{B}$ ) & D474 & $\mathrm{O}_{1}$ & 2.85 \\
\hline & Butanediol secondary $\mathrm{OH}$ (chain $\mathrm{C}$ ) & D474 & $\mathrm{O}_{1}$ & 3.02 \\
\hline & Butanediol secondary $\mathrm{OH}$ (chain D) & D474 & $\mathrm{O}_{1}$ & 2.92 \\
\hline & Average & D474 & $\mathbf{O}_{1}$ & 2.91 \\
\hline \multirow{4}{*}{$\begin{array}{c}14 \\
\mathrm{~S} \\
\text { diastereom }\end{array}$} & Butanediol primary $\mathrm{OH}$ (chain A) & H105 & $\mathrm{N}_{\varepsilon}$ & 2.94 \\
\hline & Butanediol primary $\mathrm{OH}$ (chain B) & H105 & $\mathrm{N}_{\varepsilon}$ & 2.94 \\
\hline & Butanediol primary $\mathrm{OH}$ (chain $\mathrm{C}$ ) & H105 & $\mathrm{N}_{\varepsilon}$ & 2.88 \\
\hline & Butanediol primary $\mathrm{OH}$ (chain D) & $\mathrm{H} 105$ & $\mathrm{~N}_{\varepsilon}$ & 2.94 \\
\hline
\end{tabular}




\begin{tabular}{|c|c|c|c|c|}
\hline er $(\mathrm{Q}=0.7)$ & Average & H105 & $\mathbf{N}_{\varepsilon}$ & 2.93 \\
\hline \multirow{5}{*}{$\begin{array}{c}\mathbf{1 4} \\
\mathbf{R} \\
\text { diastereom } \\
\text { er }(\mathrm{Q}=0.3)\end{array}$} & Butanediol primary $\mathrm{OH}$ (chain $\mathrm{A}$ ) & $\mathrm{H} 105$ & $\mathrm{~N}_{\varepsilon}$ & 2.99 \\
\hline & Butanediol primary $\mathrm{OH}$ (chain $\mathrm{B}$ ) & H105 & $\mathrm{N}_{\varepsilon}$ & 3.01 \\
\hline & Butanediol primary $\mathrm{OH}$ (chain $\mathrm{C}$ ) & $\mathrm{H} 105$ & $\mathrm{~N}_{\varepsilon}$ & 2.93 \\
\hline & Butanediol primary $\mathrm{OH}$ (chain $\mathrm{D}$ ) & $\mathrm{H} 105$ & $\mathrm{~N}_{\varepsilon}$ & 2.98 \\
\hline & $\begin{array}{l}\text { Average } \\
\end{array}$ & H105 & $\mathbf{N}_{\varepsilon}$ & 2.98 \\
\hline \multirow{5}{*}{$\begin{array}{c}\mathbf{1 4} \\
\mathbf{S} \\
\text { diastereom } \\
\text { er }(\mathrm{Q}=0.7)\end{array}$} & Butanediol secondary $\mathrm{OH}$ (chain $\mathrm{A}$ ) & D474 & $\mathrm{O}_{1}$ & 2.96 \\
\hline & Butanediol secondary $\mathrm{OH}$ (chain $\mathrm{B}$ ) & D474 & $\mathrm{O}_{1}$ & 2.93 \\
\hline & Butanediol secondary $\mathrm{OH}$ (chain $\mathrm{C}$ ) & D474 & $\mathrm{O}_{1}$ & 2.87 \\
\hline & Butanediol secondary $\mathrm{OH}$ (chain D) & D474 & $\mathrm{O}_{1}$ & 2.77 \\
\hline & $\begin{array}{l}\text { Average } \\
\end{array}$ & D474 & $0_{1}$ & 2.88 \\
\hline \multirow{5}{*}{$\begin{array}{c}\mathbf{1 4} \\
\mathbf{R} \\
\text { diastereom } \\
\text { er }(\mathrm{Q}=0.3)\end{array}$} & Butanediol secondary $\mathrm{OH}$ (chain $\mathrm{A}$ ) & D474 & $\mathrm{O}_{1}$ & 3.06 \\
\hline & Butanediol secondary $\mathrm{OH}$ (chain $\mathrm{B}$ ) & D474 & $\mathrm{O}_{1}$ & 3.14 \\
\hline & Butanediol secondary $\mathrm{OH}$ (chain $\mathrm{C}$ ) & D474 & $\mathrm{O}_{1}$ & 3.00 \\
\hline & Butanediol secondary $\mathrm{OH}$ (chain $\mathrm{D}$ ) & D474 & $\mathrm{O}_{1}$ & 2.99 \\
\hline & Average & D474 & $\mathbf{O}_{1}$ & 3.05 \\
\hline
\end{tabular}

\section{Small Molecule Synthesis}

\section{General Information}

All reactions were conducted in oven-dried glassware under an inert atmosphere of nitrogen or argon, unless otherwise stated. All solvents were reagent or high-performance liquid chromatography (HPLC) grade. Anhydrous $\mathrm{CH}_{2} \mathrm{Cl}_{2}$ and THF were obtained from the Pure SolveTM PS-400 system under an argon atmosphere. All reagents were purchased from commercially available sources and used as received. Reactions were magnetically stirred under a nitrogen atmosphere, unless otherwise noted and reactions were monitored by Thin layer chromatography (TLC) was performed on pre-coated silica gel 60 F-254 plates (40-55 micron, 230-400 mesh) and visualized by UV light or staining with p-anisaldehyde (acetic acid, sulfuric acid, and methanol) and heating. Reactions were cooled with a Neslab CC 100 Immersion Cooler equipped with a Neslab Cryotrol temperature probe where noted. Yields refer to chromatographically and spectroscopically pure compounds. Optical rotations were measured on a JASCO P-2000 polarimeter. Proton $\left({ }^{1} \mathrm{H}\right)$ and carbon $\left({ }^{13} \mathrm{C}\right)$ NMR spectra were recorded on a Bruker Avance III 500-MHz spectrometer, a Bruker DRX500 500-MHz spectrometer, a Bruker NEO600 $600-\mathrm{MHz}$ spectrometer, or a Bruker NEO400 $400-\mathrm{MHz}$ spectrometer. Chemical shifts $(\delta)$ are reported in parts per million $(\mathrm{ppm})$ relative to chloroform $(\delta$ 7.26) methanol ( $\delta 3.31)$, or acetone $(\delta 2.05)$ for ${ }^{1} \mathrm{H}$ NMR, and chloroform $(\delta$ 77.2) methanol $(\delta$ $49.0)$, or acetone ( $\delta 29.8)$ for ${ }^{13} \mathrm{C}$ NMR. Infrared spectra were recorded using a JASCO 480 Plus FT-IR spectrometer. High resolution mass spectra (HRMS) were recorded at the University of Pennsylvania Mass Spectroscopy Service Center on either a VG Micromass $70 / 70 \mathrm{H}$ or VG ZAB-E spectrometer. Analytical HPLC was performed with a Waters HPLC-MS system, consisting of a 515 pump and Sunfire C18 reverse phase column $(20 \mu \mathrm{L}$ injection volume, $5 \mu \mathrm{m}$ packing material, $4.5 \times 50 \mathrm{~mm}$ column dimensions) with detection accomplished by a Micromass ZQ mass spectrometer and 2996 PDA detector. Preparative scale HPLC was 
performed with a Gilson 333/334 preparative pump system equipped with a $5 \mathrm{~mL}$ injection loop, Sunfire C18 OBD column ( $5 \mu \mathrm{m}$ packing material, $19 \times 100 \mathrm{~mm}$ column dimensions) or a Chiralpak ${ }^{\circledR}$ AD-H column (5 $\mu \mathrm{m}$ packing material, 21 x $250 \mathrm{~mm}$ column dimensions) equipped with a UV-Vis dual wavelength (210 and $254 \mathrm{~nm}$ ) detector and 215 liquid handling module. Solvent systems were comprised of $\mathrm{H}_{2} \mathrm{O}$ containing $0.1 \% \mathrm{v} / \mathrm{v}$ trifluoroacetic acid, and acetonitrile containing $0.1 \% \mathrm{v} / \mathrm{v}$ trifluoroacetic acid or HPLC grade isopropanol and hexanes. SFC analyses were performed with a JASCO system equipped with a PU-280-CO $\mathrm{CO}_{2}$ plus $\mathrm{CO}_{2}$ Delivery System, a CO-2060 plus Intelligent Column Thermostat/Selector, an HC-2068-01 Heater Controller, a BP-2080 plus Automatic Back Pressure Regulator, an MD-2018 plus Photodiode Array Detector (200-648 nm), and PU-2080 plus Intelligent HPLC Pumps. Lyophilization was performed in a Labconco FreeZone 12 Plus lyophilizer (0.148 mbar). The purity of new compounds was judged by NMR and LCMS (>95\%).

Synthesis of 3,5-Substituted Common Intermediate

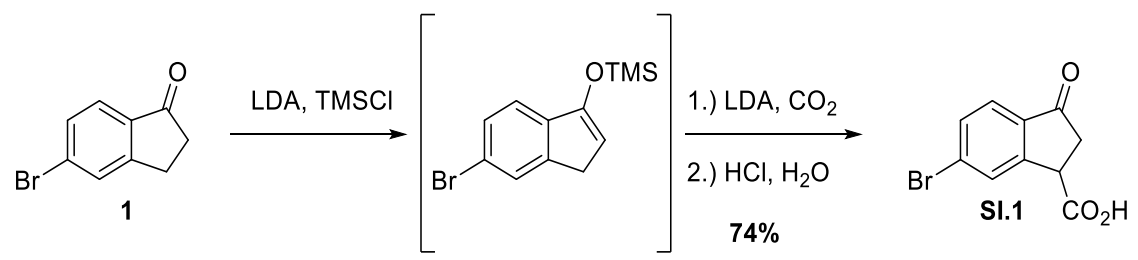

5-Bromo-3-oxo-2,3-dihydro-1H-indene-1-carboxylic acid (SI.1) To a flame dried $1 \mathrm{~L}$ roundbottomed flask with stirring bar, 5-bromoindanone (1, $10.0 \mathrm{~g}, 1.0$ equiv.) was added and capped with a septum. THF $(160 \mathrm{~mL}, 0.3 \mathrm{M})$ was then added at room temperature and the resulting solution was cooled to $-78{ }^{\circ} \mathrm{C}$ in a dry ice/acetone bath. Some precipitate formed upon cooling. A freshly prepared solution of $\operatorname{LDA}^{a}(49.75 \mathrm{~mL}, 1.0 \mathrm{M}, 1.05$ equiv.) was then added to the stirring reaction mixture over 15 minutes. The reaction was then homogenous and was stirred for 30 minutes. Freshly distilled TMSCl $(6.61 \mathrm{~mL}, 1.1$ equiv.) was then added via syringe to the reaction mixture over 15 minutes. Upon completion of this addition, the reaction was stirred for an additional 30 minutes. A second portion of LDA (56.9 mL, $1.0 \mathrm{M}, 1.2$ equiv.) was then added over 15 minutes. The reaction was then stirred for an additional 30 minutes. At this time, a balloon was used to bubble $\mathrm{CO}_{2}$ into the solution at $-78{ }^{\circ} \mathrm{C}$ for 30 minutes followed by warming to room temperature for 1 hour. The balloon was then removed along with the septum, and 3M $\mathrm{HCl}$ in water was added until $\mathrm{pH}$ paper indicated an acidic solution. The aqueous layer was extracted with EtOAc $(3 \times 200 \mathrm{~mL})$. The organic layers were then combined, washed with brine, dried over $\mathrm{Na}_{2} \mathrm{SO}_{4}$, and concentrated in vacuo to a yellow solid. The solid was then triturated with $300 \mathrm{~mL}$ of a $1: 1$ mixture of $\mathrm{CH}_{2} \mathrm{Cl}_{2}$ :hexanes and filtered to obtain a yellow crystalline solid (SI.1). The solvent of the filtrate was then concentrated in vacuo and resubjected to the same trituration conditions as described above to obtain a second crop of SI.1 (9.06 g, 74\% yield).

${ }^{1} \mathrm{H}$ NMR $\left(500 \mathrm{MHz} \mathrm{CDCl}_{3}\right) \delta 7.95(\mathrm{~s}, 1 \mathrm{H}), 7.73-7.55(\mathrm{~m}, 2 \mathrm{H}), 4.33(\mathrm{dd}, J=8.3,3.6 \mathrm{~Hz}, 1 \mathrm{H})$, $3.16(\mathrm{dd}, J=19.2,3.6 \mathrm{~Hz}, 1 \mathrm{H}), 2.92(\mathrm{dd}, J=19.2,8.2 \mathrm{~Hz}, 1 \mathrm{H}) ;{ }^{13} \mathrm{C} \mathbf{N M R}\left(150 \mathrm{MHz}, \mathrm{CDCl}_{3}\right) \delta$ 202.51, 176.16, 151.86, 135.38, 132.96, 130.71, 130.26, 125.40, 43.22, 39.32; IR (thin film, $\mathrm{KBr}) \mathrm{V}_{\max } 3127,2911,1715,1591,1408,1313,1206,1152,1045,803 \mathrm{~cm}^{-1}$; HRMS (ESI) $\mathrm{m} / \mathrm{z}$ 295.9913 [calcd for $\mathrm{C}_{12} \mathrm{H}_{11} \mathrm{BrNO}_{3}\left(\mathrm{M}+\mathrm{H}+\mathrm{CH}_{3} \mathrm{CN}\right)^{+}$295.9922].

a Method for LDA preparation: In a flame dried $500 \mathrm{~mL}$ 2-neck flask equipped with a $100 \mathrm{~mL}$ addition funnel and stir bar, diisopropylamine (freshly distilled over $\mathrm{CaH}_{2}, 15.34 \mathrm{~mL}, 1.0$ equiv.) was dissolved in anhydrous THF $(50.66 \mathrm{~mL})$ and cooled to $-78{ }^{\circ} \mathrm{C}$ in a dry ice/acetone bath. $n$ - 
BuLi (44 mL, 2.5 M in hexanes, 1.0 equiv.) was then added dropwise over 15 minutes via addition funnel. The resulting clear yellow solution $\left(V_{t}=110 \mathrm{~mL}, 1.0 \mathrm{M}\right)$ was allowed to warm to room temperature and stirred for 30 minutes. The solution was then used directly in the reaction as described above.

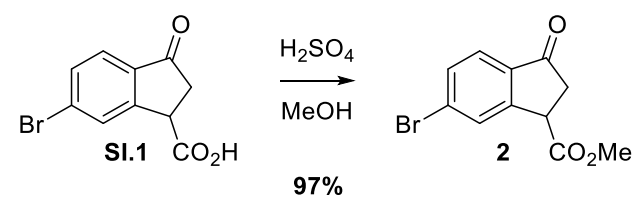

Methyl 5-bromo-3-oxo-2,3-dihydro-1H-indene-1-carboxylate (2) In a $500 \mathrm{~mL}$ round bottom flask with stir bar, SI.1 (9.06 g, 1.0 equiv.) was dissolved in methanol (72 mL, $0.5 \mathrm{M}$ ). To this solution was added 12 drops of concentrated $\mathrm{H}_{2} \mathrm{SO}_{4}$. The flask was equipped with a reflux condenser and heated to $60^{\circ} \mathrm{C}$ in an oil bath. The reaction was allowed to stir for 16 hours, or until TLC (50\% EtOAc/hexanes) indicated complete consumption of starting material. The reaction was removed from heat and allowed to cool to room temperature. A saturated aq. solution of $\mathrm{NaHCO}_{3}$ was then added until $\mathrm{pH}$ paper indicated it was basic. The aqueous layer was then extracted with EtOAc $(3 \times 150 \mathrm{~mL})$. The organic layers were then combined, washed with brine, dried over $\mathrm{Na}_{2} \mathrm{SO}_{4}$, and concentrated in vacuo. Crude 2 was used in the next reaction without further purification $(9.27 \mathrm{~g}, 97 \%$ yield).

${ }^{1} \mathrm{H}$ NMR $\left(500 \mathrm{MHz}, \mathrm{CDCl}_{3}\right) \delta 7.87(\mathrm{~s}, 1 \mathrm{H}), 7.67-7.52(\mathrm{~m}, 2 \mathrm{H}), 4.28(\mathrm{dd}, J=8.2,3.6 \mathrm{~Hz}, 1 \mathrm{H})$, $3.81(\mathrm{~s}, 3 \mathrm{H}), 3.15$ (dd, $J=19.1,3.7 \mathrm{~Hz}, 1 \mathrm{H}), 2.88(\mathrm{dd}, J=19.1,8.2 \mathrm{~Hz}, 1 \mathrm{H}) ;{ }^{13} \mathrm{C}$ NMR $(125$ $\left.\mathrm{MHz}, \mathrm{CDCl}_{3}\right) \delta 202.76,171.74,152.63,135.42,132.69,130.49,130.10,125.29,53.12,43.46$, 39.61; IR (thin film, KBr) $v_{\max }$ 2938, 1716, 1592, 1434, 1159, 1040, $820 \mathrm{~cm}^{-1}$; HRMS (EI) $\mathrm{m} / \mathrm{z}$ 267.9713 [calcd for $\mathrm{C}_{11} \mathrm{H}_{9}{ }^{79} \mathrm{BrO}_{3}(\mathrm{M})^{+}$267.9735], $\mathrm{m} / \mathrm{z} 269.9714$ [calcd for $\mathrm{C}_{11} \mathrm{H}_{9}{ }^{81} \mathrm{BrO}_{3}(\mathrm{M})^{+}$ 269.9715].

Note: Isotope overlap of $(\mathrm{M}-2 \mathrm{H})^{+}$with $\left(\mathrm{M}\left({ }^{79} \mathrm{Br}\right)\right)^{+}$skews $\left(\mathrm{M}\left({ }^{79} \mathrm{Br}\right)\right)^{+}$isotope measurement, therefore $\left(\mathrm{M}\left({ }^{81} \mathrm{Br}\right)\right)^{+}$is also supplied for further evidence.
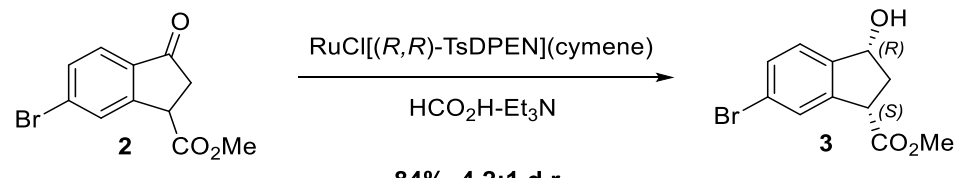

Methyl (1S,3R)-5-bromo-3-hydroxy-2,3-dihydro-1H-indene-1-carboxylate (3) In a $250 \mathrm{~mL}$ 2neck round bottom flask with stir bar, 2 (9.27 g, 1.0 equiv.) was added and capped with septa. To the flask was then added freshly distilled and sparged (30 minutes with $\mathrm{N}_{2}$ balloon) DCE (36 $\mathrm{mL}, 1.0 \mathrm{M})$ and $5: 2 \mathrm{HCO}_{2} \mathrm{H}: \mathrm{NEt}_{3}$ azeotrope $(18 \mathrm{~mL}, 0.5 \mathrm{~mL} / \mathrm{g}$ starting material). Under a positive pressure of $\mathrm{N}_{2}, \operatorname{RuCl}[(R, R)$-TsDPEN $]$ (p-cymene) (480 mg, $2 \mathrm{~mol} \%$ ) was then added in one portion to the reaction flask. The reaction was then stirred for 16 hours, at which time an aliquot was taken and showed consumption of starting material by NMR analysis. The reaction was quenched with water $(100 \mathrm{~mL})$, and the aqueous layer was extracted with $\mathrm{CH}_{2} \mathrm{Cl}_{2}(3 \times 100 \mathrm{~mL})$. The organic layers were combined, dried over $\mathrm{Na}_{2} \mathrm{SO}_{4}$, and concentrated in vacuo to a black oil. The diastereomers were separated by flash column chromatography $\left(100 \% \mathrm{CH}_{2} \mathrm{Cl}_{2}\right)$. TLC $\left(100 \% \mathrm{CH}_{2} \mathrm{Cl}_{2}\right)$ was monitored to determined when fractions began to contain the undesired diastereomer. Fractions containing the desired diastereomer were then concentrated in vacuo and dissolved in $\mathrm{Et}_{2} \mathrm{O}(300 \mathrm{~mL})$. The solvent was allowed to evaporate, forming crystals of $\mathbf{3}$ that 
were filtered and collected. NMR confirmed the d.r. to be $>20: 1$ ( $7.8 \mathrm{~g}, 84 \%$ yield of both diastereomers. Isolated $4.31 \mathrm{~g}$ of desired diastereomer).

${ }^{1} \mathrm{H}$ NMR $\left(600 \mathrm{MHz}, \mathrm{CDCl}_{3}\right) \delta 7.52(\mathrm{~d}, J=1.9 \mathrm{~Hz}, 1 \mathrm{H}), 7.45(\mathrm{dd}, J=8.0,1.8 \mathrm{~Hz}, 1 \mathrm{H}), 7.37(\mathrm{~d}, J=$ $8.0 \mathrm{~Hz}, 1 \mathrm{H}), 5.09(\mathrm{~s}, 1 \mathrm{H}), 4.00$ (dd, $J=8.1,3.0 \mathrm{~Hz}, 1 \mathrm{H}), 3.78(\mathrm{~s}, 3 \mathrm{H}), 3.13(\mathrm{~s}, 1 \mathrm{H}), 2.59$ (ddd, $J=$ 14.6, 8.0, $6.8 \mathrm{~Hz}, 1 \mathrm{H}), 2.32(\mathrm{dt}, J=14.2,2.8 \mathrm{~Hz}, 1 \mathrm{H}) ;{ }^{13} \mathrm{C}$ NMR $\left(150 \mathrm{MHz}, \mathrm{CDCl}_{3}\right) \delta 175.35$, 144.59, 142.63, 132.03, 128.23, 127.12, 122.93, 74.78, 53.10, 48.39, 38.84. IR (thin film, KBr) $V_{\max } 3309,2946,1739,1602,1434,1169,1061,819 \mathrm{~cm}^{-1}$; HRMS (EI) $\mathrm{m} / \mathrm{z} 269.9879$ [calcd for $\mathrm{C}_{11} \mathrm{H}_{11} \mathrm{BrO}_{3}(\mathrm{M})^{+}$269.9892]; [a] $]_{\mathrm{D}}^{23}+46.2\left(c 1.17, \mathrm{CH}_{2} \mathrm{Cl}_{2}\right)$.

Enantiomeric excess determined by SFC (see below):

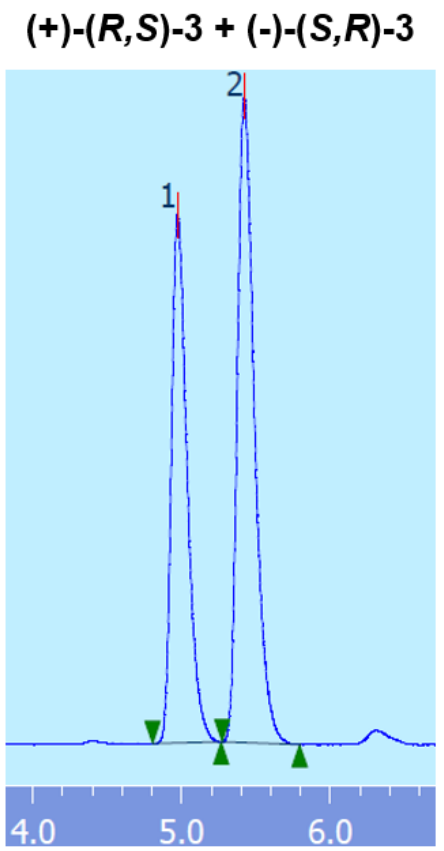

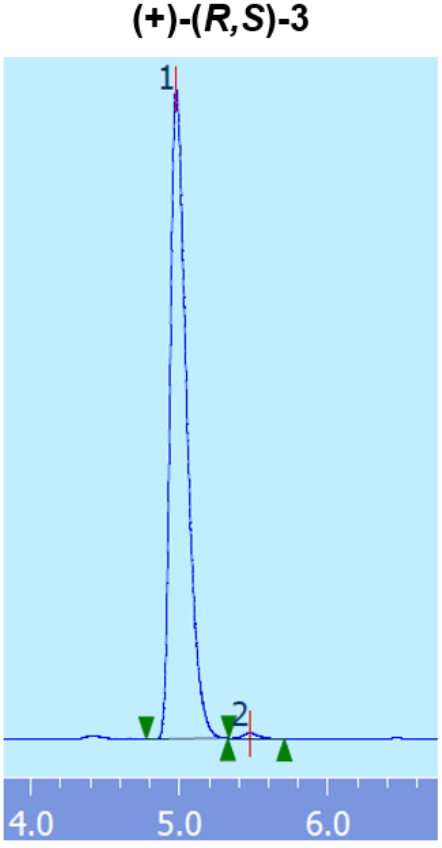

er $=99.3: 0.7$

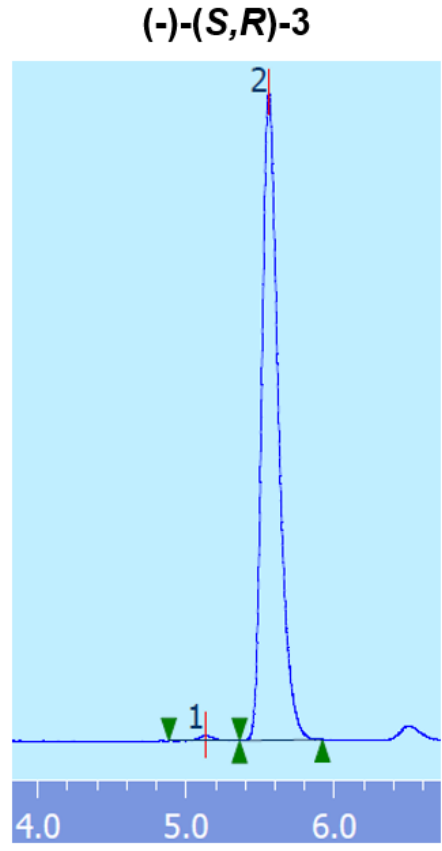

er $=99.3: 0.7$

Method: column: Chiralpak ${ }^{\circledR} \mathrm{IA}$; eluent: $5 \% \mathrm{MeOH}$ in supercritical $\mathrm{CO}_{2}$; flow rate: $4 \mathrm{~mL} / \mathrm{min}$; pressure: $12 \mathrm{MPa}$. Retention times: (+)-(R,S)-3: $5.0 \mathrm{~min},(-)-(\boldsymbol{S}, \boldsymbol{R})-3: 5.4 \mathrm{~min}$.
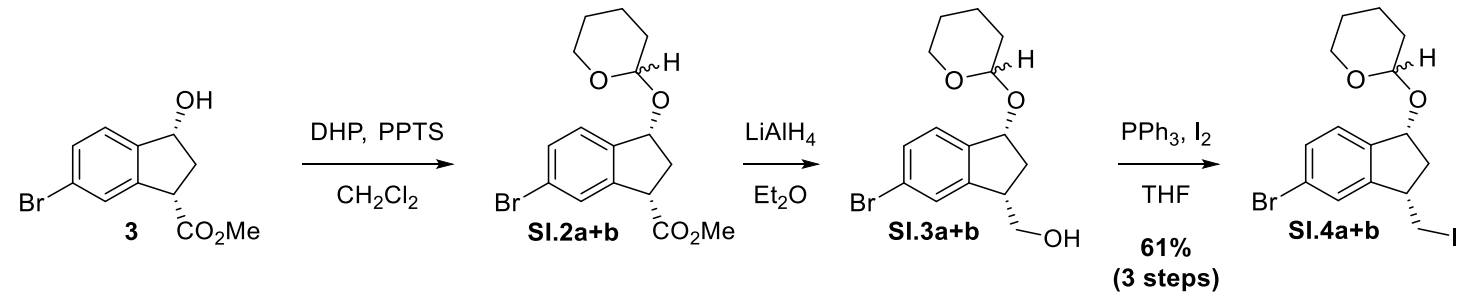

Methyl (1S,3R)-5-bromo-3-((tetrahydro-2H-pyran-2-yl)oxy)-2,3-dihydro-1H-indene-1-carboxylate (SI.2a+b) In a $250 \mathrm{~mL}$ round-bottomed flask with stir bar, 3 (4.32 g, 1.0 equiv.) was dissolved in anhydrous $\mathrm{CH}_{2} \mathrm{Cl}_{2}(48.2 \mathrm{~mL}, 0.33 \mathrm{M})$. To the stirring mixture, PPTS (200 mg, $5 \mathrm{~mol}$ $\%)$ was added in one portion at room temperature. Then, 3,4-dihydro-2H-pyran (DHP) $(2.90 \mathrm{~mL}$, 2.0 equiv.) was added in one portion. The reaction was allowed to stir overnight at room temperature. TLC (30\% EtOAc/hexanes) indicated complete consumption of starting material after 16 hours. The reaction was quenched with aq. saturated $\mathrm{NaHCO}_{3}(50 \mathrm{~mL})$ and the 
aqueous layer was extracted with $\mathrm{CH}_{2} \mathrm{Cl}_{2}(3 \times 75 \mathrm{~mL})$. The organic layers were combined, dried over $\mathrm{Na}_{2} \mathrm{SO}_{4}$, and concentrated in vacuo to an oil. The product was purified by flash column chromatography (10\% to $20 \%$ EtOAc in hexanes) to give the product $\mathbf{S I . 2 a + b}$ as a clear oil. SI.2a+b was an inseparable 1:1 diastereomeric mixture.

${ }^{1} \mathbf{H}$ NMR $\left(500 \mathrm{MHz}, \mathrm{CDCl}_{3}\right) \delta 7.57(\mathrm{~d}, J=6.3,1 \mathrm{H}), 7.44-7.40(\mathrm{~m}, 1 \mathrm{H}), 7.35(\mathrm{~d}, J=8.1 \mathrm{~Hz}$, $0.5 \mathrm{H}), 7.22(\mathrm{~d}, J=8.1 \mathrm{~Hz}, 0.5 \mathrm{H}), 5.22(\mathrm{t}, J=6.7 \mathrm{~Hz}, 0.5 \mathrm{H}), 5.02(\mathrm{t}, J=6.9 \mathrm{~Hz}, 0.5 \mathrm{H}), 4.91(\mathrm{t}, J=$ $3.6 \mathrm{~Hz}, 0.5 \mathrm{H}), 4.85(\mathrm{t}, J=3.6 \mathrm{~Hz}, 0.5 \mathrm{H}), 4.02-3.88(\mathrm{~m}, 2 \mathrm{H}), 3.78(\mathrm{~s}, 3 \mathrm{H}), 3.61-3.56(\mathrm{~m}, 1 \mathrm{H})$, 2.79 (dt, $J=13.2,7.5 \mathrm{~Hz}, 0.5 \mathrm{H}$ ), 2.71 (dt, $J=13.2,7.5 \mathrm{~Hz}, 0.5 \mathrm{H}), 2.49$ (ddd, $J=13.2,8.3,6.8$ $\mathrm{Hz}, 0.5 \mathrm{H}), 2.39$ (ddd, $J=13.1,8.0,6.4 \mathrm{~Hz}, 0.5 \mathrm{H}), 1.89-1.73(\mathrm{~m}, 2 \mathrm{H}), 1.70-1.52(\mathrm{~m}, 4 \mathrm{H}) ;{ }^{13} \mathrm{C}$ NMR $\left(100 \mathrm{MHz}, \mathrm{CDCl}_{3}\right) \delta 172.84,172.70,142.62,142.56,141.78,141.72,131.28,131.05$, $128.50,128.35,126.80,126.33,122.48,122.47,99.67,97.00,79.70,76.74,62.75$, 62.58, $52.53,52.46,47.17,47.12,38.20,35.51,31.04,30.92,25.65,19.60,19.46$; IR (thin film, $\mathrm{KBr}$ ) $V_{\max } 2946,1741,1595,1470,1435,1404,1339,1261,1200,1132,1066,1034,989,904,815$ $\mathrm{cm}^{-1}$; HRMS (EI) $\mathrm{m} / z 268.9821$ [calcd for $\mathrm{C}_{11} \mathrm{H}_{10} \mathrm{BrO}_{3}(\mathrm{M}-\mathrm{THP})^{+} 268.9813$ ]; [a] ${ }_{\mathrm{D}}^{23}+258.1$ (c $0.875, \mathrm{CH}_{2} \mathrm{Cl}_{2}$ ).

((1S,3R)-5-Bromo-3-((tetrahydro-2H-pyran-2-yl)oxy)-2,3-dihydro-1H-inden-1-yl)methanol (SI.3a+b) In a $250 \mathrm{~mL}$ 2-neck flask with stir bar, SI.2a+b (1.0 equiv.) from the previous step was added and dissolved in anhydrous $\mathrm{Et}_{2} \mathrm{O}(79 \mathrm{~mL}, 0.2 \mathrm{M})$. The solution was cooled to $0{ }^{\circ} \mathrm{C}$ in an ice/water bath. Under a positive pressure of $\mathrm{N}_{2}$, $\mathrm{LAH}$ powder $(721 \mathrm{mg}, 1.2$ equiv.) was added to the reaction flask. The reaction was stirred at $0{ }^{\circ} \mathrm{C}$ for 3 hours, at which time TLC $(30 \%$ EtOAc in hexanes) indicated complete consumption of starting material. The reaction was quenched with the Fieser \& Fieser workup ${ }^{16}\left(721 \mu \mathrm{L} \mathrm{H} \mathrm{H}_{2} \mathrm{O}, 721 \mu \mathrm{L} 20 \% \mathrm{NaOH}(\mathrm{w} / \mathrm{v})\right.$, followed by $2.16 \mathrm{~mL}$ $\mathrm{H}_{2} \mathrm{O}$ ). The reaction was then warmed to room temperature and $\mathrm{MgSO}_{4}$ was added. The mixture was allowed to stir for 15 minutes. After this time, the solid was filtered and washed thoroughly with $\mathrm{Et}_{2} \mathrm{O}(300 \mathrm{~mL})$. The filtrate was then concentrated in vacuo to a clear oil which was purified by flash column chromatography (25\% to $35 \%$ EtOAc/hexanes) to give the product SI.3a+b as a clear oil. SI.3a+b was an inseparable 1:1 diastereomeric mixture.

${ }^{1} \mathbf{H}$ NMR $\left(500 \mathrm{MHz}, \mathrm{CDCl}_{3}\right) \delta 7.49(\mathrm{~d}, J=13.2,1 \mathrm{H}), 7.41-7.33(\mathrm{~m}, 1.5 \mathrm{H}), 7.23(\mathrm{~d}, J=8.0 \mathrm{~Hz}$, $0.5 \mathrm{H}), 5.17(\mathrm{dd}, J=6.7,3.8 \mathrm{~Hz}, 0.5 \mathrm{H}), 5.08(\mathrm{dd}, J=6.6,2.9 \mathrm{~Hz}, 0.5 \mathrm{H}), 4.89(\mathrm{dd}, J=3.4,3.0 \mathrm{~Hz}$, $0.5 \mathrm{H}), 4.82(\mathrm{dd}, J=3.4,3.4 \mathrm{~Hz}, 0.5 \mathrm{H}), 3.97-3.83(\mathrm{~m}, 3 \mathrm{H}), 3.62-3.55(\mathrm{~m}, 1 \mathrm{H}), 3.33-3.28(\mathrm{~m}$, $1 \mathrm{H}), 2.64-2.52(\mathrm{~m}, 1 \mathrm{H}), 2.08-1.50(\mathrm{~m}, 9 \mathrm{H})$; IR (thin film, KBr) $\mathrm{v}_{\max } 3433,2952,1645,1474$, 1340, 1138, $1018 \mathrm{~cm}^{-1}$; HRMS (EI) $\mathrm{m} / \mathrm{z} 240.9868$ [calcd for $\mathrm{C}_{10} \mathrm{H}_{10} \mathrm{BrO}_{2}(\mathrm{M}-\mathrm{THP})^{+}$240.9864]; $[\alpha]_{D}^{23}+243.2\left(c 0.8, \mathrm{CH}_{2} \mathrm{Cl}_{2}\right)$.

\section{2-(((1R,3S)-5-Bromo-3-(iodomethyl)-2,3-dihydro-1H-inden-1-yl)oxy)tetrahydro-2H-pyran}

(SI.4a+b) In a $250 \mathrm{~mL}$ round-bottomed flask with stir bar, SI.3a+b (1.0 equiv.) from the previous step was dissolved in THF (78 mL, $0.2 \mathrm{M})$. To the stirring solution was added $\mathrm{PPh}_{3}(5.30 \mathrm{~g}, 1.3$ equiv.) and imidazole ( $1.38 \mathrm{~g}, 1.3$ equiv.) at room temperature. The reaction was then cooled to $0{ }^{\circ} \mathrm{C}$ in an ice/water bath. A solution of iodine (5.13 g, 1.3 equiv.) in THF $(20 \mathrm{~mL}, 1.0 \mathrm{M})$ was then added dropwise to the stirring reaction mixture via syringe over 15 minutes. The reaction was then warmed to room temperature and allowed to stir for 2 hours. At this time, TLC (30\% EtOAc/hexanes) indicated complete consumption of starting material. A saturated aq. solution of $\mathrm{Na}_{2} \mathrm{~S}_{2} \mathrm{O}_{3}(80 \mathrm{~mL})$ was then added and the aqueous layer was extracted with $\mathrm{Et}_{2} \mathrm{O}(3 \times 100 \mathrm{~mL})$. The organic layers were combined, dried over $\mathrm{Na}_{2} \mathrm{SO}_{4}$, and concentrated in vacuo to an oil. The product was purified by flash column chromatography (10\% EtOAc/hexanes) to give the product

\footnotetext{
${ }^{16}$ Fieser, L. F.; Fieser, M. Reagents for Organic Synthesis, 1967, 581-595.
} 
SI.4a+b as a clear oil (4.16 g, $61 \%$ over 3 steps). SI.4a+b was an inseparable 1:1 diastereomeric mixture.

${ }^{1} \mathbf{H}$ NMR $\left(400 \mathrm{MHz}, \mathrm{CDCl}_{3}\right) \delta 7.47-7.39(\mathrm{~m}, 2 \mathrm{H}), 7.34(\mathrm{~d}, J=8.7 \mathrm{~Hz}, 0.5 \mathrm{H}), 7.21(\mathrm{~d}, J=8.0 \mathrm{~Hz}$, $0.5 \mathrm{H}), 5.15(\mathrm{dd}, J=6.0,6.0 \mathrm{~Hz}, 0.5 \mathrm{H}), 5.00(\mathrm{dd}, J=6.0,6.0 \mathrm{~Hz}, 0.5 \mathrm{H}), 4.87-4.84(\mathrm{~m}, 1 \mathrm{H})$, $3.99-3.93(\mathrm{~m}, 1 \mathrm{H}), 3.62-3.54(\mathrm{~m}, 2 \mathrm{H}), 3.38-3.31(\mathrm{~m}, 1 \mathrm{H}), 2.75-2.65(\mathrm{~m}, 1 \mathrm{H}), 2.06-2.00$ $(\mathrm{m}, 0.5 \mathrm{H}), 1.90-1.70(\mathrm{~m}, 2.5 \mathrm{H}), 1.68-1.49(\mathrm{~m}, 5 \mathrm{H}) ;{ }^{13} \mathrm{C}$ NMR $\left(100 \mathrm{MHz}, \mathrm{CDCl}_{3}\right) \delta 146.58$, 146.23, 142.97, 142.75, 131.13, 130.84, 127.75, 127.39, 127.31, 126.98, 122.54, 122.47, 98.78, 97.32, 78.47, 77.40, 76.71, 62.74, 45.51, 45.22, 42.47, 40.63, 31.16, 31.00, 25.64, 19.65, 19.60, 10.94, 10.92; IR (thin film, KBr) $v_{\max } 2934,2858,1595,1469,1338,1259,1125,1034,986,869$, $815 \mathrm{~cm}^{-1} ;[\alpha]_{D}^{23}+80.7\left(c 1.99, \mathrm{CH}_{2} \mathrm{Cl}_{2}\right)$.

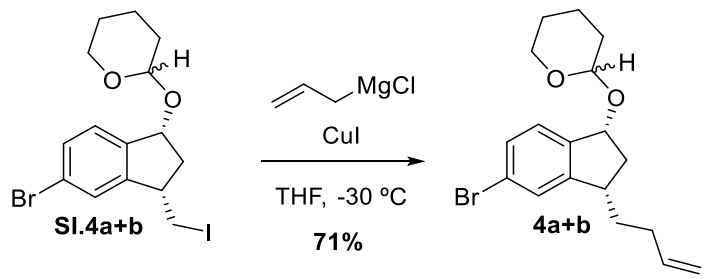

2-(((1R,3S)-5-Bromo-3-(but-3-en-1-yl)-2,3-dihydro-1H-inden-1-yl)oxy)tetrahydro-2H-pyran $(4 a+b)$ In a $250 \mathrm{~mL}$ round-bottomed with stir bar, SI.4a+b (4.16 g, 1.0 equiv.) and Cul (0.906 g, 0.4 equiv.) were added and the flask was capped with a septum. To the flask was added anhydrous THF $(50 \mathrm{~mL}, 0.2 \mathrm{M})$ and the heterogeneous mixture was cooled to $-30{ }^{\circ} \mathrm{C}$ in a xylenes/dry ice bath. Once equilibrated to $-30^{\circ} \mathrm{C}$, allylmagnesium chloride in THF $(9.51 \mathrm{~mL}, 2.0$ equiv., $2.0 \mathrm{M}$ ) was added dropwise over 10 minutes via syringe. The mixture was allowed to stir at $-30{ }^{\circ} \mathrm{C}$ for 30 minutes, followed by warming to room temperature. After an additional hour of stirring, TLC (10\% EtOAc/hexanes) indicated complete consumption of starting material. The reaction was cooled to $0{ }^{\circ} \mathrm{C}$ and quenched with brine $(50 \mathrm{~mL})$ and $33 \% \mathrm{w} / \mathrm{v}$ aqueous $\mathrm{NH}_{4} \mathrm{OH}(50$ $\mathrm{mL})$. The aqueous layer was extracted with $\mathrm{Et}_{2} \mathrm{O}(3 \times 100 \mathrm{~mL})$ and the organic layers were combined, dried over $\mathrm{Na}_{2} \mathrm{SO}_{4}$, and concentrated in vacuo to an oil. The product was purified by flash column chromatography ( $5 \%$ EtOAc/hexanes) to give the product $\mathbf{4 a + b}$ as a clear oil. ( $2.36 \mathrm{~g}, 71 \%$ yield). $\mathbf{4 a + b}$ was an inseparable $1: 1$ diastereomeric mixture.

${ }^{1} \mathrm{H}$ NMR $\left(500 \mathrm{MHz}, \mathrm{CDCl}_{3}\right) \delta 7.36-7.32(\mathrm{~m}, 2.5 \mathrm{H}), 7.19(\mathrm{~d}, J=7.9 \mathrm{~Hz}, 0.5 \mathrm{H}), 5.86$ (dddd, $J=$ 16.9, 10.2, 6.6, $6.6 \mathrm{~Hz}, 1 \mathrm{H}), 5.18(\mathrm{dd}, J=6.8,6.8 \mathrm{~Hz}, 0.5 \mathrm{H}), 5.09-5.05(\mathrm{~m}, 1 \mathrm{H}), 5.02-4.98$ $(\mathrm{m}, 1.5 \mathrm{H}), 4.90(\mathrm{t}, J=3.6 \mathrm{~Hz}, 0.5 \mathrm{H}), 4.85(\mathrm{t}, J=3.6 \mathrm{~Hz}, 0.5 \mathrm{H}), 4.03-3.94(\mathrm{~m}, 1 \mathrm{H}), 3.61-3.56$ $(\mathrm{m}, 1 \mathrm{H}), 3.03-2.95(\mathrm{~m}, 1 \mathrm{H}), 2.68$ (ddt, $J=12.5,9.5,7.1 \mathrm{~Hz}, 1 \mathrm{H}), 2.26-2.10(\mathrm{~m}, 2 \mathrm{H}), 2.06-$ $1.96(\mathrm{~m}, 1 \mathrm{H}), 1.91-1.74(\mathrm{~m}, 2.5 \mathrm{H}), 1.69-1.52(\mathrm{~m}, 5.5 \mathrm{H}) ;{ }^{13} \mathbf{C}$ NMR $\left(125 \mathrm{MHz} \mathrm{CDCl}_{3}\right) \delta$ 149.06 , 148.85, 142.72, 142.69, 138.51, 138.42, 130.07, 129.84, 127.19, 126.92, 126.49, 126.09, 122.21, 122.13, 115.12, 115.06, 99.75, 96.98, 80.14, 62.90, 62.66, 41.63, 41.47, 41.46, 39.36, 34.63, 34.61, 31.84, 31.77, 31.18, 31.10, 25.67, 25.64, 19.83, 19.64; IR (thin film, KBr) $\mathrm{V}_{\max }$ 3073, 2925, 1639, 1597, 1470, 1338, 1200, 1133, 1063, 1035, 993, 910, 869, $813 \mathrm{~cm}^{-1}$; HRMS (El) $\mathrm{m} / \mathrm{z} 350.0883$ [calcd for $\mathrm{C}_{18} \mathrm{H}_{23} \mathrm{BrO}_{2}(\mathrm{M})^{+} 350.0881$ ]; [a] ${ }^{23}+40.1$ (c 1.25, $\mathrm{CH}_{2} \mathrm{Cl}_{2}$ ).

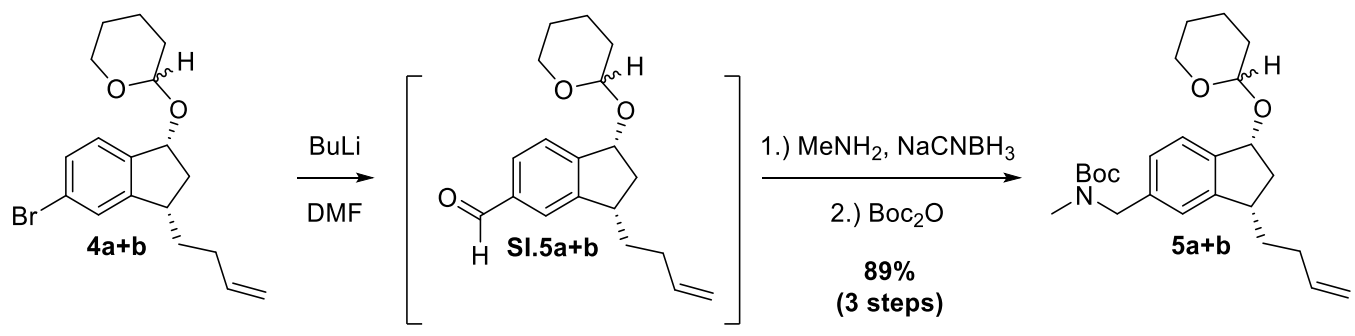


Tert-butyl (((1R,3S)-3-(but-3-en-1-yl)-1-((tetrahydro-2H-pyran-2-yl)oxy)-2,3-dihydro-1H-inden-5-yl)methyl)(methyl)carbamate (5a+b) In an oven-dried $100 \mathrm{~mL}$ round-bottomed flask with stir bar, $4 \mathbf{a}+\mathbf{b}$ ( $2.36 \mathrm{~g}, 1.0$ equiv.) was added and the flask was capped with a septum. To the flask was added anhydrous THF $(22.5 \mathrm{~mL}, 0.3 \mathrm{M})$ and the solution was cooled to $-78{ }^{\circ} \mathrm{C}$ in an acetone/dry ice bath. Once equilibrated, $n$-butyllithium in hexanes (2.95 mL, 1.1 equiv., $2.5 \mathrm{M})$ was added dropwise via syringe over 10 minutes. The reaction was allowed to stir for 15 minutes before addition of DMF (620 $\mu \mathrm{L}, 1.2$ equiv.). The reaction was allowed to stir for 15 minutes and was warmed to room temperature. The reaction was allowed to stir for an additional 30 minutes at room temperature when TLC (10\% EtOAc/hexanes) indicated complete consumption of starting material. The reaction was quenched with brine $(50 \mathrm{~mL})$ and the aqueous layer was extracted with EtOAc $(3 \times 50 \mathrm{~mL})$. The organic layers were combined, dried over $\mathrm{Na}_{2} \mathrm{SO}_{4}$, and concentrated in vacuo to give crude $\mathbf{S I . 5 a + b}$ as a clear oil. This material was used in the next step without further purification.

To a solution of crude $\mathbf{S I} .5 \mathbf{a}+\mathbf{b}$ in $\mathrm{MeOH} / \mathrm{CH}_{2} \mathrm{Cl}_{2}(5: 1$ ratio, $7.89 \mathrm{~mL}, 0.85 \mathrm{M})$ was added $40 \mathrm{wt} \%$ aqueous $\mathrm{MeNH}_{2}\left(1.97 \mathrm{~mL}, 3.4\right.$ equiv) at $0{ }^{\circ} \mathrm{C}$. The resulting solution was stirred at $0{ }^{\circ} \mathrm{C}$ for 1 hour, followed by the addition of $\mathrm{NaBH}_{4}(0.66 \mathrm{~g}, 2.6$ equiv) in one portion. The resulting suspension was continued to stir at $0 \stackrel{\circ}{\circ} \mathrm{C}$ for 2 hours, or until TLC $(10 \% \mathrm{EtOAc} / \mathrm{hexanes})$ indicated complete consumption of starting material. The reaction mixture was then treated with an aqueous saturated solution of $\mathrm{NaHCO}_{3}(20 \mathrm{~mL})$. The resulting mixture was allowed to warm to room temperature and extracted with $\mathrm{CH}_{2} \mathrm{Cl}_{2}(3 \times 20 \mathrm{~mL})$. The organic layers were combined, dried over $\mathrm{Na}_{2} \mathrm{SO}_{4}$, and concentrated in vacuo to give an oil. This was dissolved in $\mathrm{CH}_{2} \mathrm{Cl}_{2}(6.71$ $\mathrm{mL}$ ) and this solution was cooled to $0^{\circ} \mathrm{C}$, to which a solution of $\mathrm{Boc}_{2} \mathrm{O}(1.70 \mathrm{~mL}, 1.05$ equiv) in $\mathrm{CH}_{2} \mathrm{Cl}_{2}$ (3.2 mL, $2.3 \mathrm{M}$ ) was added dropwise. The reaction mixture was warmed to room temperature and stirred for 1 hour. The solvent was then concentrated in vacuo to give crude $5 \mathbf{a}+\mathbf{b}$ as an oil, which was purified by flash column chromatography (10\% EtOAc/hexanes) to give the product $\mathbf{5} \mathbf{a}+\mathbf{b}$ as a clear oil $(2.49 \mathrm{~g}, 89 \%$ over 3 steps). $\mathbf{5} \mathbf{a}+\mathbf{b}$ was an inseparable $1: 1$ diastereomeric mixture.

${ }^{1} \mathrm{H}$ NMR $\left(500 \mathrm{MHz}, \mathrm{CDCl}_{3}\right) \delta 7.41(\mathrm{~d}, J=7.7 \mathrm{~Hz}, 0.5 \mathrm{H}), 7.28(\mathrm{~d}, J=8.2 \mathrm{~Hz}, 0.5 \mathrm{H}), 7.19-6.98$ (m, 2H), 5.86 (dddd, $J=16.9,11.3,6.4,6.4 \mathrm{~Hz}, 1 \mathrm{H}), 5.27-5.23(\mathrm{~m}, 0.5 \mathrm{H}), 5.07-5.04(\mathrm{~m}$, $1.5 \mathrm{H}), 5.00-4.93(\mathrm{~m}, 1.5 \mathrm{H}), 4.88-4.86(\mathrm{~m}, 0.5 \mathrm{H}), 4.41(\mathrm{~s}, 2 \mathrm{H}), 4.05(\mathrm{ddd}, J=11.7,8.5,3.5$ $\mathrm{Hz}, 0.5 \mathrm{H}$ ), 3.98 (ddd, $J=11.2,7.4,3.4 \mathrm{~Hz}, 0.5 \mathrm{H}), 3.62-3.56(\mathrm{~m}, 1 \mathrm{H}), 3.07-2.94(\mathrm{~m}, 1 \mathrm{H}), 2.82$ $-2.66(\mathrm{~m}, 4 \mathrm{H}), 2.26-2.11(\mathrm{~m}, 2 \mathrm{H}), 2.08-1.99(\mathrm{~m}, 1 \mathrm{H}), 1.94-1.48(\mathrm{~m}, 17 \mathrm{H}) ;{ }^{13} \mathrm{C}$ NMR $(100$ $\left.\mathrm{MHz}, \mathrm{CDCl}_{3}\right) \delta 156.13,148.25,148.10,147.22,147.02,142.83,142.79,142.68,138.80$, $138.71,138.25,138.21,138.19,124.92$, 124.66, 124.60, 124.32, 114.93, 114.88, 99.86, 99.80, $96.73,96.65,80.69,80.53,79.79,77.40,62.91,62.75,62.52,62.48,52.83,44.26,43.32,42.13$, $41.65,41.56,41.51,39.43,36.68,36.57,34.87,34.85,34.01,33.97,32.00,31.94,31.24,31.20$, $31.18,28.66,25.77,25.72,20.40,19.91,19.81,19.62,19.60$; IR (thin film, $\mathrm{KBr}$ ) $\mathrm{V}_{\max } 3074$, 2929, 2863, 1698, 1453, 1391, 1136, 1034, 992, 913, 870, $816 \mathrm{~cm}^{-1}$; HRMS (ESI) $\mathrm{m} / \mathrm{z} 438.2614$

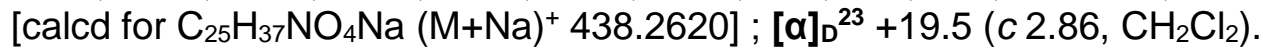

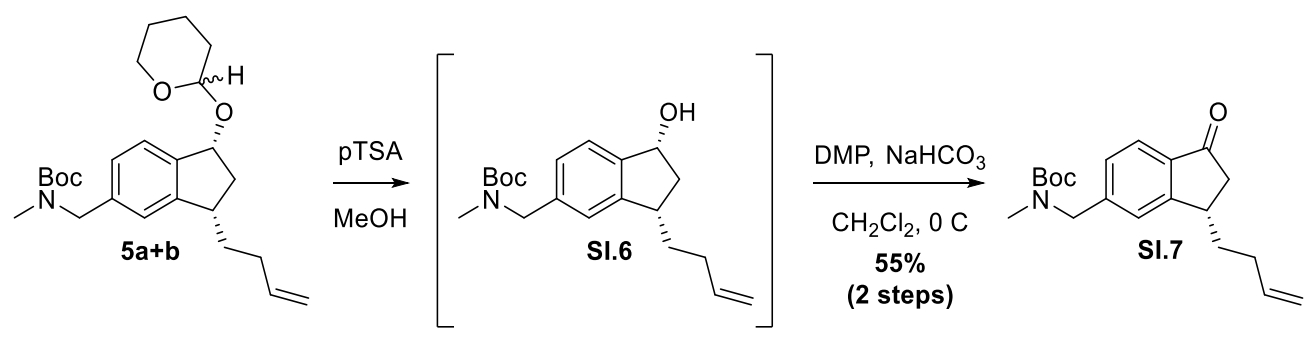


Tert-butyl (S)-((3-(but-3-en-1-yl)-1-oxo-2,3-dihydro-1H-inden-5-yl)methyl)(methyl) carbamate (SI.7) To a solution of $\mathbf{5 a}+\mathbf{b}(2.49 \mathrm{~g}, 1.0$ equiv.) in $\mathrm{MeOH}(100 \mathrm{~mL}, 0.06 \mathrm{M})$ was added $p$ TSA (251 mg, 0.22 equiv) at room temperature. The resulting solution was stirred at room temperature for 1 hour, at which time TLC (20\% EtOAc/hexanes) indicated complete consumption of starting material. The reaction mixture was then treated with a saturated aq. solution of $\mathrm{NaHCO}_{3}(50 \mathrm{~mL})$ and extracted with EtOAc $(3 \times 50 \mathrm{~mL})$. The organic layers were combined, dried over $\mathrm{Na}_{2} \mathrm{SO}_{4}$, and concentrated in vacuo to give crude Sl.6 as an oil. This residue was taken up in anhydrous $\mathrm{CH}_{2} \mathrm{Cl}_{2}(60 \mathrm{~mL}, 0.1 \mathrm{M})$ and solid $\mathrm{NaHCO}_{3}(2.02 \mathrm{~g}, 4.0$ equiv) was added at room temperature. The resulting suspension was cooled to at $0{ }^{\circ} \mathrm{C}$ in an ice/water bath and DMP (3.82 g, 1.5 equiv) was then added in one portion. The reaction was then warmed to room temperature and was allowed to stir for 1 hour, at which time TLC $(20 \%$ EtOAc/hexanes) indicated complete consumption of starting material. The reaction mixture was then treated with a saturated aq. solution of $\mathrm{Na}_{2} \mathrm{~S}_{2} \mathrm{O}_{3}(60 \mathrm{~mL})$. The resulting mixture was extracted with $\mathrm{CH}_{2} \mathrm{Cl}_{2}(3 \times 60 \mathrm{~mL})$. The organic layers were combined, dried over $\mathrm{Na}_{2} \mathrm{SO}_{4}$, and concentrated in vacuo to give an oil, which was purified by flash column chromatography $(15 \%$ EtOAc/hexanes) to give SI.7 (1.09 g, 55\% yield, 2 steps).

${ }^{1} \mathrm{H}$ NMR $\left(500 \mathrm{MHz}, \mathrm{CDCl}_{3}\right) \delta 7.69(\mathrm{~d}, J=7.9 \mathrm{~Hz}, 1 \mathrm{H}), 7.33(\mathrm{~s}, 1 \mathrm{H}), 7.22(\mathrm{~d}, J=7.8 \mathrm{~Hz}, 1 \mathrm{H})$, 5.83 (dddd, $J=16.9,10.2,6.6,6.6 \mathrm{~Hz}, 1 \mathrm{H}), 5.07-5.00(\mathrm{~m}, 2 \mathrm{H}), 4.50(\mathrm{~s}, 2 \mathrm{H}), 3.39-3.34(\mathrm{~m}$, $1 \mathrm{H}), 2.90-2.82(\mathrm{~m}, 4 \mathrm{H}), 2.37(\mathrm{dd}, J=18.9,3.3 \mathrm{~Hz}, 1 \mathrm{H}), 2.19-2.14(\mathrm{~m}, 2 \mathrm{H}), 2.04-1.98(\mathrm{~m}$, $1 \mathrm{H}), 1.70-1.31(\mathrm{~m}, 10 \mathrm{H}) ;{ }^{13} \mathrm{C}$ NMR $\left(125 \mathrm{MHz}, \mathrm{CDCl}_{3}\right) \delta 205.78,159.46,145.92,137.84$, 136.22, 123.98, 115.57, 80.22, 43.37, 37.76, 35.47, 34.54, 31.94, 28.59; IR (thin film, KBr) $\mathrm{V}_{\max }$ 3080, 2981, 2927, 1713, 1608, 1394, 1237, 1145, 1046, $877 \mathrm{~cm}^{-1}$; HRMS (ESI) $\mathrm{m} / z$ 330.2064 [calcd for $\left.\mathrm{C}_{20} \mathrm{H}_{28} \mathrm{NO}_{3}(\mathrm{M}+\mathrm{H})^{+} 330.2069\right] ;[\alpha]_{D}^{23}+20.6\left(c 0.85, \mathrm{CH}_{2} \mathrm{Cl}_{2}\right)$.

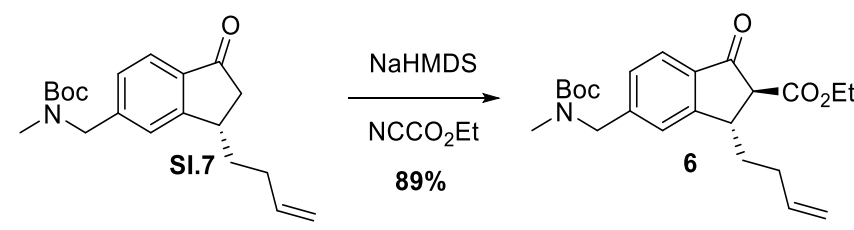

Ethyl (2S,3S)-3-(but-3-en-1-yl)-5-(((tert-butoxycarbonyl)(methyl)amino)methyl)-1-oxo-2,3dihydro-1H-indene-2-carboxylate (6) In an oven dried $100 \mathrm{~mL}$ round-bottomed flask with stir bar, SI.7 (1.09 g, 1.0 equiv.) was dissolved in anhydrous THF (33.1 mL, $0.1 \mathrm{M})$. This solution was then cooled to $-78^{\circ} \mathrm{C}$ in a dry ice/acetone bath. A solution of NaHMDS in THF (6.62 mL, $1.0 \mathrm{M}, 2.1$ equiv.) was then added dropwise to the stirring solution. After 30 minutes, Mander's reagent $(0.425 \mathrm{~mL}, 1.3$ equiv.) was added dropwise. The reaction was allowed to stir for an additional hour. The flask was warmed to room temperature and was quenched with brine (50 $\mathrm{mL})$. The aqueous layer was then extracted with EtOAc $(3 \times 50 \mathrm{~mL})$. The organic layers were combined, dried over $\mathrm{Na}_{2} \mathrm{SO}_{4}$, and concentrated in vacuo to give an oil. The oil was then purified by flash column chromatography (15\% EtOAc/hexanes) to give 6 as a yellow oil ( $1.18 \mathrm{~g}$, $89 \%$ yield).

${ }^{1} \mathrm{H}$ NMR $\left(500 \mathrm{MHz}, \mathrm{CDCl}_{3}\right) \delta 7.70(\mathrm{~d}, J=8.0 \mathrm{~Hz}, 1 \mathrm{H}), 7.34(\mathrm{~s}, 1 \mathrm{H}), 7.25(\mathrm{~s}, 1 \mathrm{H}), 5.82$ (dddd, $J=$ 16.9, 10.3, 6.5, $6.5 \mathrm{~Hz}, 1 \mathrm{H}), 5.07-5.00(\mathrm{~m}, 2 \mathrm{H}), 4.50(\mathrm{~s}, 2 \mathrm{H}), 4.23(\mathrm{q}, J=7.1 \mathrm{~Hz}, 2 \mathrm{H}), 3.79-$ $3.72(\mathrm{~m}, 1 \mathrm{H}), 3.37(\mathrm{~d}, J=4.0 \mathrm{~Hz}, 1 \mathrm{H}), 2.86-2.78(\mathrm{~s}, 3 \mathrm{H}), 2.21-2.07(\mathrm{~m}, 3 \mathrm{H}), 1.71-1.59(\mathrm{~m}$, $1 \mathrm{H}), 1.48(\mathrm{~s}, 9 \mathrm{H}), 1.29(\mathrm{t}, J=7.1 \mathrm{~Hz}, 3 \mathrm{H}) ;{ }^{13} \mathrm{C}$ NMR $\left(125 \mathrm{MHz}, \mathrm{CDCl}_{3}\right) \delta$ 198.65, 169.43, 159.44, 158.04, 147.03, 137.39, 134.51, 127.13, 124.88, 123.96, 123.58, 115.91, 80.28, 61.83, 60.58, 53.04, 52.36, 42.58, 34.68, 31.72, 29.85, 28.61, 28.56, 14.35; IR (thin film, $\mathrm{KBr}$ ) $\mathrm{v}_{\max } 3073$, 2976, 2929, 2850, 1696, 1608, 1566, 1466, 1401, 1146, 1016, 914, $877 \mathrm{~cm}^{-1}$; HRMS (ESI) m/z 402.2278 [calcd for $\mathrm{C}_{23} \mathrm{H}_{32} \mathrm{NO}_{5}(\mathrm{M}+\mathrm{H})^{+} 402.2280$ ]; [ [ ] $]_{\mathrm{D}}^{23}-49.8\left(c 1.11, \mathrm{CH}_{2} \mathrm{Cl}_{2}\right)$. 


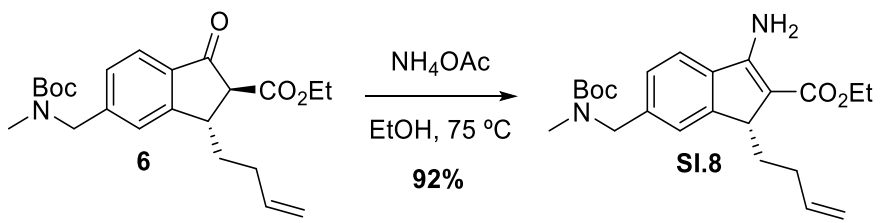

Ethyl (R)-3-amino-1-(but-3-en-1-yl)-6-(((tert-butoxycarbonyl)(methyl)amino)methyl)-1Hind-ene-2-carboxylate (SI.8) In a $100 \mathrm{~mL}$ round-bottomed flask with stir bar, 6 (1.18 g, 1.0 equiv.) and ammonium acetate (2.27 g, 10 equiv.) were dissolved in ethanol $(7.35 \mathrm{~mL}, 0.4 \mathrm{M})$ at room temperature. The flask was fitted with a reflux condenser and heated to $75{ }^{\circ} \mathrm{C}$ in an oil bath. After 16 hours, TLC indicated complete consumption of starting material $(20 \%$ EtOAc/hexanes). The reaction was then cooled to room temperature and quenched with aq. sat. $\mathrm{NaHCO}_{3}(20 \mathrm{~mL})$ and the aqueous layer was extracted with $\mathrm{CH}_{2} \mathrm{Cl}_{2}(3 \times 20 \mathrm{~mL})$. The organic layers were combined, dried over $\mathrm{Na}_{2} \mathrm{SO}_{4}$, and concentrated in vacuo to give a brown oil, which was purified by flash column chromatography (15\% EtOAc/hexanes) to give SI.8 as a yellow oil ( $1.08 \mathrm{~g}, 92 \%$ yield).

${ }^{1} \mathrm{H}$ NMR $\left(500 \mathrm{MHz}, \mathrm{CDCl}_{3}\right) \delta 7.34-7.29(\mathrm{~m}, 2 \mathrm{H}), 7.21$ (s, 1H), 6.00 (br s, 2H), 5.69 (dddd, $J=$ 16.9, 10.2, 6.6, $6.6 \mathrm{~Hz}, 1 \mathrm{H}), 4.88-4.82(\mathrm{~m}, 2 \mathrm{H}), 4.49(\mathrm{~s}, 2 \mathrm{H}), 4.32(\mathrm{dq}, J=10.7,7.1 \mathrm{~Hz}, 1 \mathrm{H})$, $4.22(\mathrm{dq}, J=10.8,7.1 \mathrm{~Hz}, 1 \mathrm{H}), 3.82(\mathrm{dd}, J=5.0,4.4 \mathrm{~Hz}, 1 \mathrm{H}), 2.83(\mathrm{~s}, 3 \mathrm{H}), 2.17-2.07(\mathrm{~m}, 2 \mathrm{H})$, $1.86-1.78(\mathrm{~m}, 1 \mathrm{H}), 1.58-1.43(\mathrm{~m}, 10 \mathrm{H}), 1.34(\mathrm{t}, J=7.1 \mathrm{~Hz}, 3 \mathrm{H}) ;{ }^{13} \mathrm{C} \mathrm{NMR}\left(125 \mathrm{MHz}, \mathrm{CDCl}_{3}\right)$ $\delta$ 167.98, 156.26, 149.37, 139.48, 139.22, 136.97, 126.38, 125.79, 122.82, 118.96, 114.16, 101.76, 79.99, 59.10, 53.04, 52.30, 45.37, 34.29, 30.59, 28.81, 28.63, 14.89; IR (thin film, KBr) $\mathrm{V}_{\max } 3451,3341,2976,2915,1664,1536,1391,1265,1139 \mathrm{~cm}^{-1}$; HRMS (ESI) $\mathrm{m} / \mathrm{z} 401.2427$ [calcd for $\mathrm{C}_{23} \mathrm{H}_{33} \mathrm{~N}_{2} \mathrm{O}_{4}(\mathrm{M}+\mathrm{H})^{+} 401.2440$ ]; [ $\left.\alpha\right]_{D}^{23}-15.3\left(c 1.26, \mathrm{CH}_{2} \mathrm{Cl}_{2}\right)$.

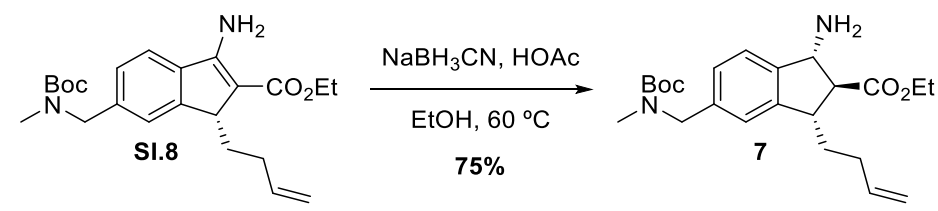

Ethyl (1R,2S,3S)-1-amino-3-(but-3-en-1-yl)-5-(((tert-butoxycarbonyl)(methyl)amino)methyl)-2,3-dihydro-1H-indene-2-carboxylate (7) In a $100 \mathrm{~mL}$ round-bottomed flask with stir bar, SI.8, (1.08 g, 1.0 equiv.), $\mathrm{NaBH}_{3} \mathrm{CN}$ (1.02 g, 6 equiv.), and $\mathrm{AcOH}$ (1.23 mL, 8 equiv.) were dissolved in ethanol $(9.0 \mathrm{~mL}, 0.3 \mathrm{M})$ at room temperature. The flask was sealed with a septum and fitted with a reflux condenser. The reaction was heated to $60^{\circ} \mathrm{C}$ in an oil bath and allowed to stir overnight. After 16 hours, TLC indicated complete consumption of starting material $(50 \%$ EtOAc/hexanes) with the product staining well in $\mathrm{KMnO}_{4}$. The reaction was then cooled to room temperature and quenched with $1 \mathrm{M} \mathrm{NaOH}(10 \mathrm{~mL})$ and the aqueous layer was extracted with $\mathrm{CH}_{2} \mathrm{Cl}_{2}(3 \times 20 \mathrm{~mL})$. The organic layers were combined, dried over $\mathrm{Na}_{2} \mathrm{SO}_{4}$, and concentrated in vacuo to give an oil, which was purified by flash column chromatography $(50 \%$ to $100 \%$ EtOAc/hexanes) to give 7 as a yellow oil $(0.808 \mathrm{~g}, 75 \%$ yield).

${ }^{1} \mathrm{H}$ NMR $\left(500 \mathrm{MHz}, \mathrm{CDCl}_{3}\right) \delta 7.28(\mathrm{~d}, J=7.7 \mathrm{~Hz}, 1 \mathrm{H}), 7.13-7.03(\mathrm{~m}, 2 \mathrm{H}), 5.84$ (dddd, $J=16.8$, 10.2, 6.3, 6.3 Hz, 1H), $5.08-5.02(\mathrm{~m}, 1 \mathrm{H}), 5.00-4.97(\mathrm{~m}, 1 \mathrm{H}), 4.48(\mathrm{~d}, J=8.4 \mathrm{~Hz}, 1 \mathrm{H}), 4.41$ (s, 2H), $4.29-4.21(\mathrm{~m}, 2 \mathrm{H}), 3.47-3.41(\mathrm{~m}, 1 \mathrm{H}), 2.81(\mathrm{~s}, 3 \mathrm{H}), 2.57(\mathrm{dd}, J=8.9,8.9 \mathrm{~Hz}, 1 \mathrm{H})$, $2.19-2.04(\mathrm{~m}, 3 \mathrm{H}), 1.91(\mathrm{~s}, 2 \mathrm{H}), 1.75-1.67(\mathrm{~m}, 1 \mathrm{H}), 1.47(\mathrm{~s}, 9 \mathrm{H}), 1.32(\mathrm{t}, J=7.2 \mathrm{~Hz}, 3 \mathrm{H}) ;{ }^{13} \mathrm{C}$ NMR $\left(125 \mathrm{MHz}, \mathrm{CDCl}_{3}\right) \delta 174.59,145.44,144.43,143.54,138.29,126.64,123.60,115.07$, $79.90,63.30,61.03,60.65,52.78,45.09,34.06,33.43,31.41,30.95,28.64,14.51$; IR (thin film, $\mathrm{KBr}) \mathrm{v}_{\max } 3366,3074,2976,2921,2402,2350,2251,1695,1462,1392,1234,1147,1032,874$ $\mathrm{cm}^{-1}$; HRMS (ESI) $\mathrm{m} / \mathrm{z} 403.2608$ [calcd for $\mathrm{C}_{23} \mathrm{H}_{35} \mathrm{~N}_{2} \mathrm{O}_{4}(\mathrm{M}+\mathrm{H})^{+}$403.2597]; [a] ${ }^{23}-2.1$ (c 1.51, $\mathrm{CH}_{2} \mathrm{Cl}_{2}$ ). 


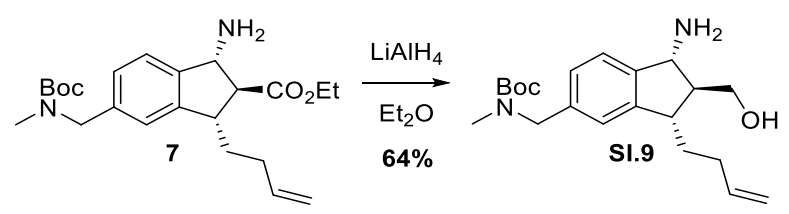

Tert-butyl (((1R,2S,3S)-1-amino-3-(but-3-en-1-yl)-2-(hydroxymethyl)-2,3-dihydro-1H-inden5-yl)methyl)(methyl)carbamate (SI.9) In a $100 \mathrm{~mL}$ round-bottomed flask with stir bar, 7 (808 $\mathrm{mg}, 1.0$ equiv.) was added and dissolved in anhydrous $\mathrm{Et}_{2} \mathrm{O}(9.6 \mathrm{~mL}, 0.2 \mathrm{M})$. The solution was then cooled to $0{ }^{\circ} \mathrm{C}$ in an ice/water bath. LAH powder (146 mg, 1.2 equiv.) was added to the reaction flask. The reaction was stirred at $0{ }^{\circ} \mathrm{C}$ for 2 hours, at which time TLC $(10 \%$ $\mathrm{MeOH} / \mathrm{CH}_{2} \mathrm{Cl}_{2}$ ) indicated complete consumption of starting material. The reaction was quenched with the Fieser \& Fieser ${ }^{16}$ workup $\left(150 \mu \mathrm{L} \mathrm{H} \mathrm{H}_{2} \mathrm{O}, 150 \mu \mathrm{L} 20 \% \mathrm{NaOH}(\mathrm{w} / \mathrm{v})\right.$, followed by $450 \mu \mathrm{L}$ $\mathrm{H}_{2} \mathrm{O}$ ). The reaction was then warmed to room temperature and $\mathrm{MgSO}_{4}$ was added. The mixture was allowed to stir for 30 minutes. After this time, the solid was filtered and washed thoroughly with $\mathrm{Et}_{2} \mathrm{O}$. The filtrate was then concentrated in vacuo to an oil, which was purified by flash column chromatography $\left(10 \% \mathrm{MeOH} / \mathrm{CH}_{2} \mathrm{Cl}_{2}\right)$ to give SI.9 as a yellow oil $(441 \mathrm{mg}, 64 \%)$.

${ }^{1} \mathrm{H}$ NMR $\left(500 \mathrm{MHz}, \mathrm{CDCl}_{3}\right) \delta 7.22(\mathrm{~d}, J=7.7 \mathrm{~Hz}, 1 \mathrm{H}), 7.10-7.05$ (m, 2H) 5.83 (dddd, $J=16.8$, $10.2,6.5,6.5 \mathrm{~Hz}, 1 \mathrm{H}), 5.06-5.02(\mathrm{~m}, 1 \mathrm{H}), 4.98-4.96(\mathrm{~m}, 1 \mathrm{H}), 4.40(\mathrm{~s}, 2 \mathrm{H}), 4.15(\mathrm{~d}, J=8.4$ $\mathrm{Hz}, 1 \mathrm{H}), 4.06(\mathrm{dd}, J=10.4,4.3 \mathrm{~Hz}, 1 \mathrm{H}), 3.86(\mathrm{dd}, J=9.8,9.8 \mathrm{~Hz}, 1 \mathrm{H}), 2.88-2.73(\mathrm{~m}, 7 \mathrm{H}), 2.19$ $-2.12(\mathrm{~m}, 2 \mathrm{H}), 2.08-2.01(\mathrm{~m}, 1 \mathrm{H}), 1.95-1.88(\mathrm{~m}, 1 \mathrm{H}), 1.81-1.73(\mathrm{~m}, 1 \mathrm{H}), 1.47(\mathrm{~s}, 9 \mathrm{H}) ;{ }^{13} \mathrm{C}$ NMR $\left(125 \mathrm{MHz}, \mathrm{CDCl}_{3}\right) \delta 156.30,155.91,145.49,145.20,138.50,137.88,126.65,126.29$, $123.13,122.77,115.08,79.85,66.19,61.23,57.61,52.78,52.10,43.14,34.01,32.51,31.24$, 28.63; IR (thin film, KBr) $V_{\max } 3353,3074,2975,2925,2361,1694,1482,1453,1393,1366$, 1302, 1246, 1172, 1148, 909, 874, 932, $818 \mathrm{~cm}^{-1}$; HRMS (ESI) $\mathrm{m} / \mathrm{z} 361.2500$ [calcd for $\mathrm{C}_{21} \mathrm{H}_{33} \mathrm{~N}_{2} \mathrm{O}_{3}(\mathrm{M}+\mathrm{H})^{+}$361.2491]; [a] $]_{\mathrm{D}}^{23}+3.6\left(c 0.75, \mathrm{CH}_{2} \mathrm{Cl}_{2}\right)$.

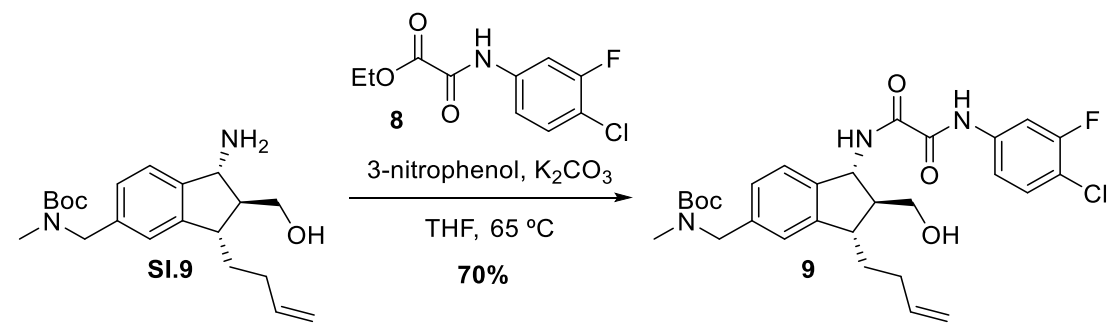

Tert-butyl (((1R,2S,3S)-3-(but-3-en-1-yl)-1-(2-((4-chloro-3-fluorophenyl)amino)-2-oxoacetamido)-2-(hydroxymethyl)-2,3-dihydro-1H-inden-5-yl)methyl)(methyl)carbamate (9) In a 25 $\mathrm{mL}$ round-bottomed flask equipped with a reflux condenser and stir bar, a mixture of SI.9 (441 $\mathrm{mg}, 1.0$ equiv.), 8 (340 mg, 1.15 equiv.), 3-nitrophenol (33.6 mg, 0.2 equiv.), and $\mathrm{K}_{2} \mathrm{CO}_{3}$ (33.3 $\mathrm{mg}, 0.2$ equiv.) in THF ( $1.505 \mathrm{~mL}, 0.8 \mathrm{M}$ ) was stirred at $65^{\circ} \mathrm{C}$ for $16 \mathrm{~h}$. The resulting suspension was allowed to cool to room temperature and then treated with 10 wt $\% \mathrm{~K}_{2} \mathrm{CO}_{3}(5 \mathrm{~mL})$. The resulting mixture was further stirred at room temperature for $1 \mathrm{hr}$, and then diluted with EtOAc $(20 \mathrm{~mL})$. The aqueous layer was extracted with EtOAc $(3 \times 20 \mathrm{~mL})$. The organic layers were combined, dried over $\mathrm{Na}_{2} \mathrm{SO}_{4}$, and concentrated in vacuo to give an oil, which was purified by flash column chromatography (50\% to $100 \%$ EtOAc/hexanes) to give 9 as a colorless amorphous solid (472 mg, 70\% yield).

${ }^{1} \mathrm{H}$ NMR $\left(400 \mathrm{MHz}, \mathrm{CDCl}_{3}\right) \delta 9.48(\mathrm{~s}, 1 \mathrm{H}), 7.93(\mathrm{~d}, J=8.5 \mathrm{~Hz}, 1 \mathrm{H}), 7.71$ (dd, $J=10.6,2.4 \mathrm{~Hz}$, $1 \mathrm{H}), 7.37(\mathrm{t}, J=8.3 \mathrm{~Hz}, 1 \mathrm{H}), 7.28(\mathrm{dd}, J=2.6,1.0 \mathrm{~Hz}, 1 \mathrm{H}), 7.21(\mathrm{~d}, J=7.7 \mathrm{~Hz}, 1 \mathrm{H}), 7.14-7.12$ (m, 2H), 5.83 (dddd, $J=16.8,10.1,6.5,6.5 \mathrm{~Hz}, 1 \mathrm{H}), 5.20$ (dd, $J=8.5,6.0 \mathrm{~Hz}, 1 \mathrm{H}$ ), $5.07-4.98$ 
(m, 2H), $4.43(\mathrm{~s}, 2 \mathrm{H}), 3.86(\mathrm{dd}, J=11.5,4.1 \mathrm{~Hz}, 1 \mathrm{H}), 3.73(\mathrm{dd}, J=11.4,8.3 \mathrm{~Hz}, 1 \mathrm{H}), 2.92(\mathrm{q}, J$ $=6.8 \mathrm{~Hz}, 1 \mathrm{H}), 2.82(\mathrm{~s}, 3 \mathrm{H}), 2.58-2.38(\mathrm{~s}, 1 \mathrm{H}), 2.31-2.10(\mathrm{~m}, 3 \mathrm{H}), 1.97-1.89(\mathrm{~m}, 1 \mathrm{H}), 1.81-$ $1.72(\mathrm{~m}, 1 \mathrm{H}), 1.48(\mathrm{~s}, 9 \mathrm{H}) ;{ }^{13} \mathrm{C}$ NMR $\left(125 \mathrm{MHz}, \mathrm{CDCl}_{3}\right) \delta 160.18,158.18\left(\mathrm{~d}, J_{C F}=248.5 \mathrm{~Hz}\right)$, 157.24, 146.44, 139.67, 138.72, 138.08, $136.33\left(\mathrm{~d}, J_{C F}=9.8 \mathrm{~Hz}\right), 131.04,124.43,117.51\left(\mathrm{~d}, J_{C F}\right.$ $=18.4 \mathrm{~Hz}), 116.26\left(\mathrm{~d}, J_{C F}=3.7 \mathrm{~Hz}\right), 115.43,108.72\left(\mathrm{~d}, J_{C F}=26.2 \mathrm{~Hz}\right), 80.01,68.67,64.21$, 58.18, 57.67, 44.60, 34.19, 31.18, 28.63, 27.97, 22.36; IR (thin film, KBr) $\mathbf{V}_{\max } 3353$, 3287, 3075, 2975, 2926, 1671, 1594, 1514, 1454, 1427, 1394, 1366, 1304, 1243, 1150, 1066, $973 \mathrm{~cm}^{-1}$; HRMS (ESI) $\mathrm{m} / \mathrm{z} 560.2335$ [calcd for $\mathrm{C}_{29} \mathrm{H}_{36} \mathrm{ClFN}_{3} \mathrm{O}_{5}(\mathrm{M}+\mathrm{H})^{+}$560.2328]; [a] ${ }^{23}-10.0$ (c 1.75, $\mathrm{CH}_{2} \mathrm{Cl}_{2}$ ).

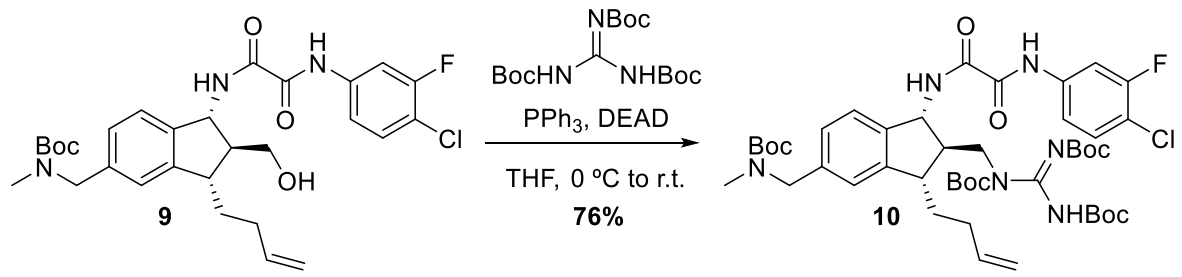

Compound $10 \mathrm{In}$ a $100 \mathrm{~mL}$ round-bottomed flask with stir bar, a mixture of 9 (472 mg, 1.0 equiv.), $\mathrm{PPh}_{3}$ (354 mg, 1.6 equiv.), and N,N',N"-tri-Boc-guanidine (1.06 g, 3.5 equiv.) in anhydrous THF $(21.1 \mathrm{~mL}, 0.04 \mathrm{M})$ was stirred at room temperature until a well-dispersed suspension had formed. This mixture was cooled at $0 \stackrel{\circ}{ } \mathrm{C}$ and treated with diethyl azodicarboxylate (198 $\mu \mathrm{L}, 1.5$ equiv.) dropwise at such a rate that each drop was only added after the color change resulting from the previous drop had dissipated. After the addition was completed, the reaction was allowed to warm to room temperature and stir for $18 \mathrm{hr}$. TLC (30\% EtOAc/hexanes) indicated complete consumption of starting material at this time. The reaction was then quenched with brine $(25 \mathrm{~mL})$ and the aqueous layer was extracted with EtOAc $(3 \times 25$ $\mathrm{mL}$ ). The organic layers were combined, dried over $\mathrm{Na}_{2} \mathrm{SO}_{4}$, and concentrated in vacuo to give a white solid which was purified by flash column chromatography (20\% EtOAc/hexanes) to give a mixture of 10 and $\mathrm{N}, \mathrm{N}^{\prime}, \mathrm{N}^{\prime \prime}$-tri-Boc-guanidine. The residue was treated with $\mathrm{Et}_{2} \mathrm{O}(5 \mathrm{~mL})$ and the insoluble material was removed via vacuum filtration. The filtrate was concentrated in vacuo to give 10 as an off-white amorphous solid (576 mg, 76\%).

${ }^{1} \mathrm{H}$ NMR $\left(500 \mathrm{MHz}, \mathrm{CDCl}_{3}\right) \delta 10.32(\mathrm{~s}, 1 \mathrm{H}), 9.29$ (s, 1H), 7.81 (s, 1H), 7.71 (dd, J= 10.6, $2.4 \mathrm{~Hz}$, $1 \mathrm{H}), 7.36(\mathrm{t}, J=8.3 \mathrm{~Hz}, 1 \mathrm{H}), 7.21-7.17(\mathrm{~m}, 2 \mathrm{H}), 7.11-7.05(\mathrm{~m}, 2 \mathrm{H}), 5.83$ (dddd, $J=16.8$, 10.2, 6.5, $6.5 \mathrm{~Hz}, 1 \mathrm{H}), 5.25(\mathrm{dd}, J=8.3,5.6 \mathrm{~Hz}, 1 \mathrm{H}), 5.10-5.06(\mathrm{~m}, 1 \mathrm{H}), 5.01-4.98(\mathrm{~m}, 1 \mathrm{H})$ $4.42(\mathrm{~s}, 2 \mathrm{H}), 4.08-4.01(\mathrm{~m}, 2 \mathrm{H}), 2.90-2.76(\mathrm{~m}, 4 \mathrm{H}), 2.62-2.57(\mathrm{~m}, 1 \mathrm{H}), 2.26-2.16(\mathrm{~m}, 2 \mathrm{H})$, $1.91-1.77(\mathrm{~m}, 2 \mathrm{H}), 1.47(\mathrm{~s}, 36 \mathrm{H}) ;{ }^{13} \mathrm{C}$ NMR $\left(125 \mathrm{MHz}, \mathrm{CDCl}_{3}\right) \delta 159.18,158.25$ (d, J JF $=248.5$ $\mathrm{Hz}$ ), 157.66, 153.62, 146.13, 139.76, 139.02, 138.34, 136.61 (d, $\left.J_{C F}=9.7 \mathrm{~Hz}\right), 130.98,124.85$, $117.09\left(\mathrm{~d}, J_{C F}=18.4 \mathrm{~Hz}\right), 115.93\left(\mathrm{~d}, J_{C F}=3.2 \mathrm{~Hz}\right), 115.38,108.41\left(\mathrm{~d}, J_{C F}=26.2 \mathrm{~Hz}\right), 83.90$, 58.42, 51.74, 49.88, 46.39, 34.09, 31.28, 28.65, 28.52, 28.41, 28.25, 28.18, 28.17; IR (thin film, $\mathrm{KBr}) \mathrm{V}_{\max } 3276,3075,2977,2931,1758,1683,1607,1508,1455,1427,1394,1368,1247$, 1140, 1060, 872, $854 \mathrm{~cm}^{-1}$; HRMS (ESI) $\mathrm{m} / \mathrm{z} 901.4263$ [calcd for $\mathrm{C}_{45} \mathrm{H}_{63} \mathrm{CIFN}_{6} \mathrm{O}_{10}(\mathrm{M}+\mathrm{H})^{+}$

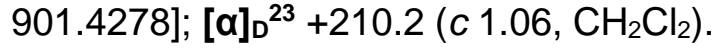

Synthesis of 3,6-Substituted Common Intermediate 


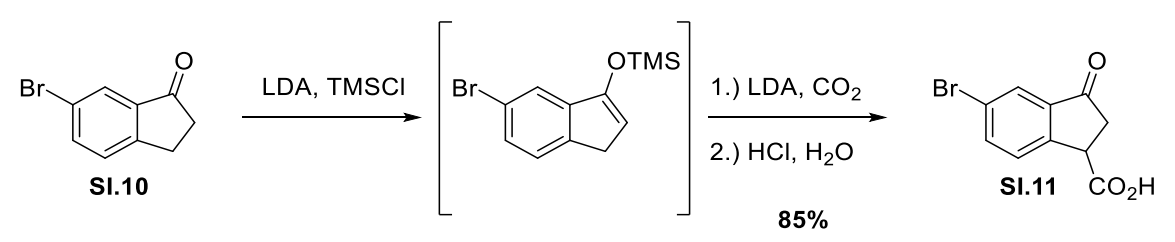

6-Bromo-3-oxo-2,3-dihydro-1H-indene-1-carboxylic acid (SI.11) To a flame dried $1 \mathrm{~L}$ roundbottomed flask with stirring bar, 6-bromoindanone (SI.10, $10.0 \mathrm{~g}, 1.0$ equiv.) was added and capped with a septum. THF $(160 \mathrm{~mL}, 0.3 \mathrm{M})$ was then added at room temperature and the resulting solution was cooled to $-78^{\circ} \mathrm{C}$ in a dry ice/acetone bath. Some precipitate formed upon cooling. A freshly prepared solution of $\operatorname{LDA}^{\mathrm{a}}(49.75 \mathrm{~mL}, 1.0 \mathrm{M}, 1.05$ equiv.) was then added to the stirring reaction mixture over 15 minutes. The reaction was then homogenous and was stirred for 30 minutes. Freshly distilled TMSCI $(6.61 \mathrm{~mL}, 1.1$ equiv.) was then added via syringe to the reaction mixture over 15 minutes. Upon completion of this addition, the reaction was stirred for an additional 30 minutes. A second portion of LDA (56.9 mL, $1.0 \mathrm{M}, 1.2$ equiv.) was then added over 15 minutes. The reaction was then stirred for an additional 30 minutes. At this time, a balloon was used to bubble $\mathrm{CO}_{2}$ into the solution at $-78{ }^{\circ} \mathrm{C}$ for 30 minutes followed by warming to room temperature for 1 hour. The balloon was then removed along with the septum, and $3 \mathrm{M} \mathrm{HCl}$ in water was added until $\mathrm{pH}$ paper indicated an acidic solution. The aqueous layer was extracted with EtOAc $(3 \times 200 \mathrm{~mL})$. The organic layers were then combined, washed with brine, dried over $\mathrm{Na}_{2} \mathrm{SO}_{4}$, and concentrated in vacuo to a yellow solid. The solid was then triturated with $300 \mathrm{~mL}$ of a 1:1 mixture of $\mathrm{CH}_{2} \mathrm{Cl}_{2}$ :hexanes and filtered to obtain a yellow crystalline solid (SI.11). The solvent of the filtrate was then concentrated in vacuo and resubjected to the same trituration conditions as described above to obtain a second crop of SI.11 (10.3 g, 85\% yield).

${ }^{1} \mathbf{H}$ NMR $\left(500 \mathrm{MHz}, \mathrm{CDCl}_{3}\right) \delta 7.90(\mathrm{~d}, J=2.0 \mathrm{~Hz}, 1 \mathrm{H}), 7.76(\mathrm{dd}, J=8.3,1.9 \mathrm{~Hz}, 1 \mathrm{H}), 7.64(\mathrm{~d}, J=$ $8.2 \mathrm{~Hz}, 1 \mathrm{H}), 4.28(\mathrm{dd}, J=8.2,3.5 \mathrm{~Hz}, 1 \mathrm{H}), 3.17(\mathrm{dd}, J=19.3,3.5 \mathrm{~Hz}, 1 \mathrm{H}), 2.93(\mathrm{dd}, J=19.2$, $8.1 \mathrm{~Hz}, 1 \mathrm{H}) ;{ }^{13} \mathrm{C}$ NMR $\left(125 \mathrm{MHz}, \mathrm{CDCl}_{3}\right) \delta 202.21,176.44,148.91,138.31,138.13,128.47$, 127.26, 123.84, 43.22, 39.57; IR (thin film, KBr) $v_{\max } 3127,2911,1715,1591,1408,1313,1206$, 1152, 1045, $803 \mathrm{~cm}^{-1}$; HRMS (EI) $\mathrm{m} / z 253.9584$ [calcd for $\mathrm{C}_{10} \mathrm{H}_{7} \mathrm{BrO}_{3}(\mathrm{M})^{+}$253.9579].

a Method for LDA preparation: In a flame dried $500 \mathrm{~mL}$ 2-neck flask equipped with a $100 \mathrm{~mL}$ addition funnel and stir bar, diisopropylamine (freshly distilled over $\mathrm{CaH}_{2}, 15.34 \mathrm{~mL}, 1.0$ equiv.) was dissolved in anhydrous THF $(50.66 \mathrm{~mL})$ and cooled to $-78{ }^{\circ} \mathrm{C}$ in a dry ice/acetone bath. $n$ BuLi (44 mL, $2.5 \mathrm{M}$ in hexanes, 1.0 equiv.) was then added dropwise over 15 minutes via addition funnel. The resulting clear yellow solution $\left(\mathrm{V}_{\mathrm{t}}=110 \mathrm{~mL}, 1.0 \mathrm{M}\right)$ was allowed to warm to room temperature and stirred for 30 minutes. The solution was then used directly in the reaction as described above.

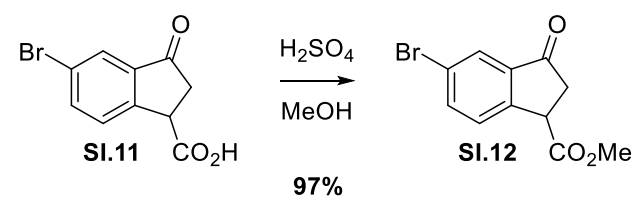

Methyl 6-bromo-3-oxo-2,3-dihydro-1H-indene-1-carboxylate (SI.12) In a $500 \mathrm{~mL}$ round bottom flask with stir bar, SI.11 (10.3 g, 1.0 equiv.) was dissolved in methanol ( $80 \mathrm{~mL}, 0.5 \mathrm{M})$. To this solution was added 15 drops of concentrated $\mathrm{H}_{2} \mathrm{SO}_{4}$. The flask was equipped with a reflux condenser and heated to $60^{\circ} \mathrm{C}$ in an oil bath. The reaction was allowed to stir for 16 hours, or until TLC (50\% EtOAc/hexanes) indicated complete consumption of starting material. 
The reaction was removed from heat and allowed to cool to room temperature. A saturated aq. solution of $\mathrm{NaHCO}_{3}$ was then added until $\mathrm{pH}$ paper indicated it was basic. The aqueous layer was then extracted with EtOAc $(3 \times 200 \mathrm{~mL})$. The organic layers were then combined, washed with brine, dried over $\mathrm{Na}_{2} \mathrm{SO}_{4}$, and concentrated in vacuo. Crude SI.12 was used in the next reaction without further purification (10.4 g, 97\% yield).

${ }^{1} \mathbf{H}$ NMR $\left(600 \mathrm{MHz}, \mathrm{CDCl}_{3}\right) \delta 7.88(\mathrm{~d}, J=1.9 \mathrm{~Hz}, 1 \mathrm{H}), 7.73(\mathrm{dd}, J=8.2,1.9 \mathrm{~Hz}, 1 \mathrm{H}), 7.58(\mathrm{~d}, J=$ $8.2 \mathrm{~Hz}, 1 \mathrm{H}), 4.24(\mathrm{dd}, J=8.1,3.5 \mathrm{~Hz}, 1 \mathrm{H}), 3.78(\mathrm{~s}, 3 \mathrm{H}), 3.16(\mathrm{dd}, J=19.2,3.6 \mathrm{~Hz}, 1 \mathrm{H}), 2.91$ (dd, $J=19.2,8.1 \mathrm{~Hz}, 1 \mathrm{H}) ;{ }^{13} \mathrm{C}$ NMR $\left(150 \mathrm{MHz} \mathrm{CDCl}_{3}\right) \delta 202.56,171.80,149.70,138.31$, 137.94, 128.35, 127.09, 123.48, 53.02, 43.44, 39.83; IR (thin film, KBr) $v_{\max } 3001,2951,2929$, 1725, 1714, 1594, 1574, 1434, 1339, 1194, 1171, 1160, 1056, $986 \mathrm{~cm}^{-1}$; HRMS (EI) m/z 267.9724 [calcd for $\mathrm{C}_{11} \mathrm{H}_{9} \mathrm{BrO}_{3}(\mathrm{M})^{+}$267.9735].
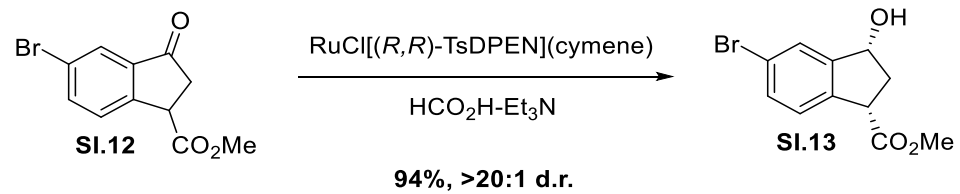

Methyl (1S,3R)-6-bromo-3-hydroxy-2,3-dihydro-1H-indene-1-carboxylate (SI.13) In a 250 $\mathrm{mL}$ 2-neck round bottom flask with stir bar, SI.12 (10.4 g, 1.0 equiv.) was added and capped with septa. To the flask was then added freshly distilled and sparged (30 minutes with $\mathrm{N}_{2}$ balloon) DCE $(40 \mathrm{~mL}, 1.0 \mathrm{M})$ and $5: 2 \mathrm{HCO}_{2} \mathrm{H}: \mathrm{NEt}_{3}$ azeotrope $(21 \mathrm{~mL}, 0.5 \mathrm{~mL} / \mathrm{g}$ starting material). Under a positive pressure of $\mathrm{N}_{2}, \mathrm{RuCl}[(R, R)$-TsDPEN]$(p$-cymene) $(490 \mathrm{mg}, 2 \mathrm{~mol} \%)$ was then added in one portion to the reaction flask. The reaction was then stirred for 16 hours, at which time an aliquot was taken and showed consumption of starting material by NMR analysis. The reaction was quenched with water $(100 \mathrm{~mL})$, and the aqueous layer was extracted with $\mathrm{CH}_{2} \mathrm{Cl}_{2}(3 \times 150 \mathrm{~mL})$. The organic layers were combined, dried over $\mathrm{Na}_{2} \mathrm{SO}_{4}$, and concentrated in vacuo to a black oil. This was dissolved in $\mathrm{Et}_{2} \mathrm{O}(400 \mathrm{~mL})$ and the solvent was allowed to evaporate, forming crystals of SI.13 that were filtered and collected. NMR confirmed the d.r. to be $>20: 1$ ( $10.4 \mathrm{~g}, 94 \%$ yield of both diastereomers).

${ }^{1} \mathrm{H}$ NMR $\left(600 \mathrm{MHz}, \mathrm{CDCl}_{3}\right) \delta 7.63(\mathrm{~d}, J=1.6 \mathrm{~Hz}, 1 \mathrm{H}), 7.42(\mathrm{dd}, J=8.1,1.9 \mathrm{~Hz}, 1 \mathrm{H}), 7.24(\mathrm{~d}, J=$ $8.1 \mathrm{~Hz}, 1 \mathrm{H}), 5.11(\mathrm{dd}, J=6.8,2.5 \mathrm{~Hz}, 1 \mathrm{H}), 3.96(\mathrm{dd}, J=8.0,3.1 \mathrm{~Hz}, 1 \mathrm{H}), 3.76(\mathrm{~s}, 3 \mathrm{H}), 2.60$ (ddd, $J=14.7,8.0,6.9 \mathrm{~Hz}, 1 \mathrm{H}), 2.32(\mathrm{dt}, J=14.1,2.9 \mathrm{~Hz}, 1 \mathrm{H}) ;{ }^{13} \mathrm{C}$ NMR $\left(150 \mathrm{MHz}, \mathrm{CDCl}_{3}\right) \delta$ 175.23, 147.58, 139.19, 132.00, 128.72, 126.41, 122.45, 74.81, 52.83, 47.92, 38.69; IR (thin film, KBr) $V_{\max } 3281,2951,1745,1468,1336,1265,1210,1173,1066,961,852 \mathrm{~cm}^{-1}$; HRMS (El) $\mathrm{m} / \mathrm{z} 269.9881$ [calcd for $\mathrm{C}_{11} \mathrm{H}_{11} \mathrm{BrO}_{3}(\mathrm{M})^{+}$269.9892]; [a] ${ }^{23}-51.6$ (c 0.47, $\left.\mathrm{CH}_{2} \mathrm{Cl}_{2}\right)$.

Enantiomeric excess determined by SFC (see below): 


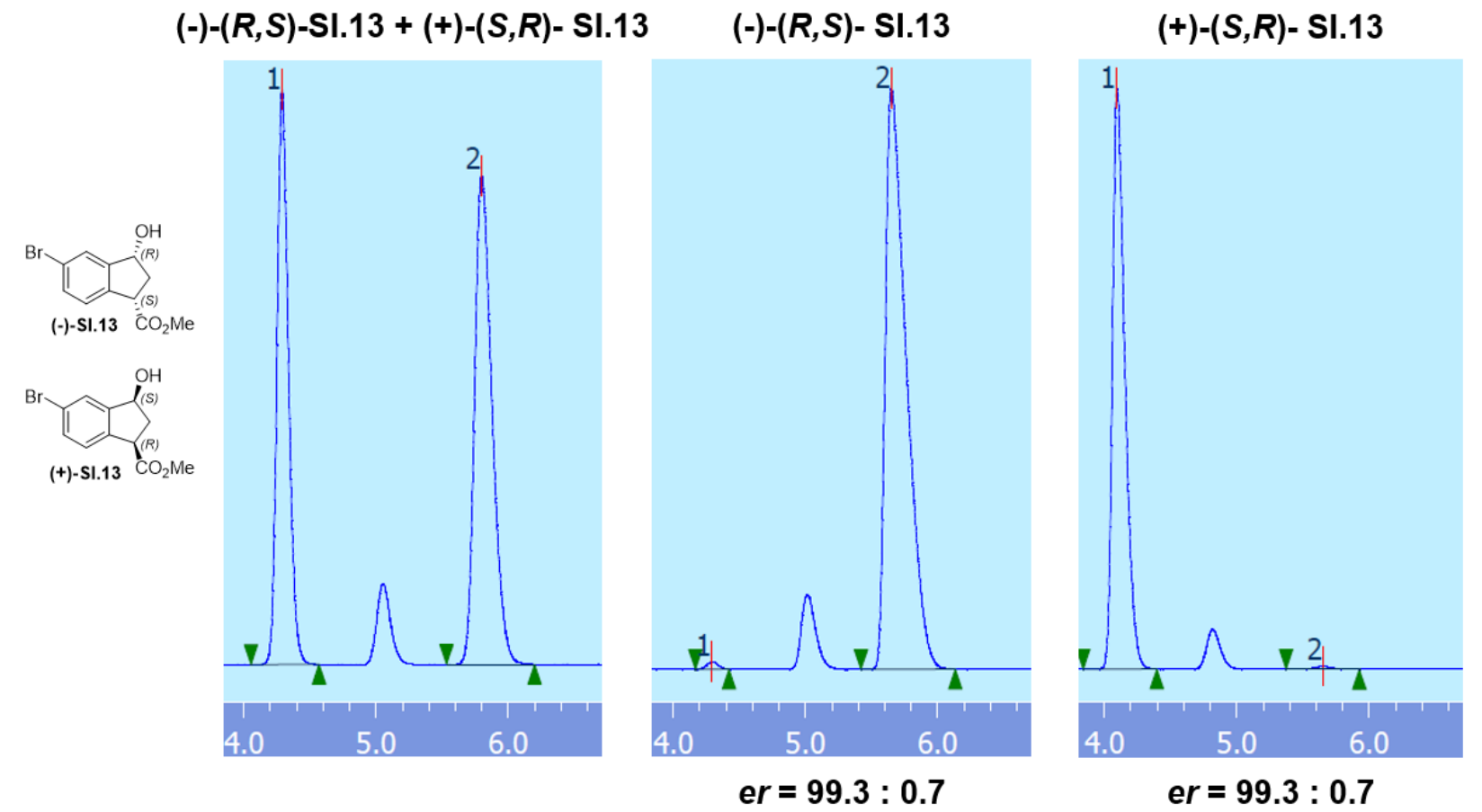

Method: column: Chiralpak ${ }^{\circledR} \mathrm{IA}$; eluent: $7 \% \mathrm{MeOH}$ in supercritical $\mathrm{CO}_{2}$; flow rate: $4 \mathrm{~mL} / \mathrm{min}$; pressure: $12 \mathrm{MPa}$. Retention times: (-)-(R,S)-SI.13: $4.3 \mathrm{~min},(+)-(\boldsymbol{S}, \boldsymbol{R})-\mathbf{S I} .13: 5.8 \mathrm{~min}$.

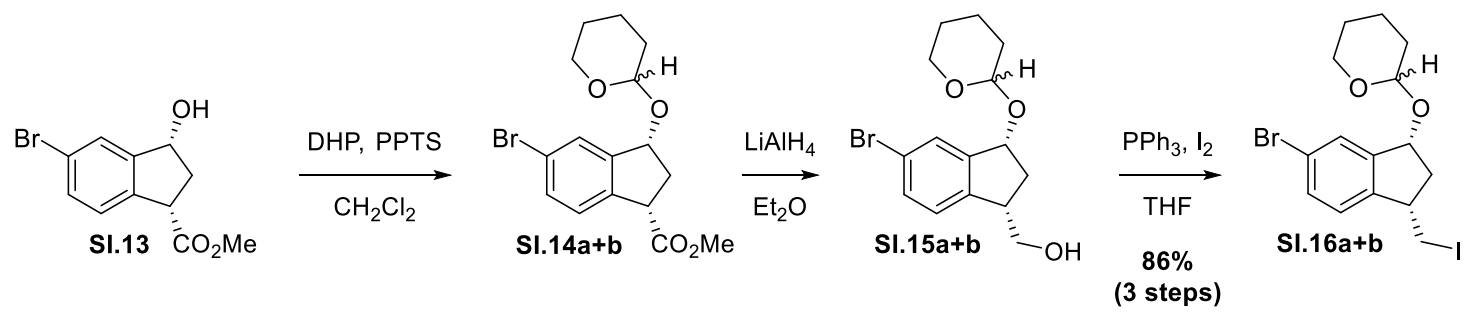

Methyl (1S,3R)-6-bromo-3-((tetrahydro-2H-pyran-2-yl)oxy)-2,3-dihydro-1H-indene-1-carboxylate (SI.14a+b) In a $250 \mathrm{~mL}$ round-bottomed flask with stir bar, SI.13 (6.62 g, 1.0 equiv.) was dissolved in anhydrous $\mathrm{CH}_{2} \mathrm{Cl}_{2}(74 \mathrm{~mL}, 0.33 \mathrm{M}$ ). To the stirring mixture, PPTS (307 mg, $5 \mathrm{~mol}$ $\%$ ) was added in one portion at room temperature. Then, 3,4-dihydro-2H-pyran (DHP) $(4.46 \mathrm{~mL}$, 2.0 equiv.) was added in one portion. The reaction was allowed to stir overnight at room temperature. TLC (30\% EtOAc/hexanes) indicated complete consumption of starting material after 16 hours. The reaction was quenched with aq. saturated $\mathrm{NaHCO}_{3}(100 \mathrm{~mL})$ and the aqueous layer was extracted with $\mathrm{CH}_{2} \mathrm{Cl}_{2}(3 \times 100 \mathrm{~mL})$. The organic layers were combined, dried over $\mathrm{Na}_{2} \mathrm{SO}_{4}$, and concentrated in vacuo to an oil. The product was purified by flash column chromatography (10\% to $20 \%$ EtOAc in hexanes) to give the product $\mathbf{S I . 1 4 a + b}$ as a clear oil. SI.14a+b was an inseparable 1:1 diastereomeric mixture.

${ }^{1} \mathrm{H}$ NMR $\left(600 \mathrm{MHz}, \mathrm{CDCl}_{3}\right) \delta 7.61(\mathrm{~s}, 0.5 \mathrm{H}), 7.48(\mathrm{~s}, 0.5 \mathrm{H}), 7.41(\mathrm{~d}, J=8.1 \mathrm{~Hz}, 1 \mathrm{H}), 7.29(\mathrm{t}, J=$ $7.6 \mathrm{~Hz}, 1 \mathrm{H}), 5.26(\mathrm{t}, J=6.8 \mathrm{~Hz}, 0.5 \mathrm{H}), 5.05(\mathrm{t}, J=7.1 \mathrm{~Hz}, 0.5 \mathrm{H}), 4.92(\mathrm{t}, J=3.3 \mathrm{~Hz}, 0.5 \mathrm{H}), 4.86$ $(\mathrm{t}, J=3.5 \mathrm{~Hz}, 0.5 \mathrm{H}), 4.02-3.94(\mathrm{~m}, 1 \mathrm{H}), 3.89-3.83(\mathrm{~m}, 1 \mathrm{H}), 3.76(\mathrm{~s}, 3 \mathrm{H}), 3.61-3.56(\mathrm{~m}, 1 \mathrm{H})$, 2.81 (dt, $J=13.3,7.5 \mathrm{~Hz}, 0.5 \mathrm{H}$ ), 2.73 (dt, $J=13.1,7.5 \mathrm{~Hz}, 0.5 \mathrm{H}$ ), $2.50-2.45(\mathrm{~m}, 0.5 \mathrm{H}), 2.40-$ $2.35(\mathrm{~m}, 0.5 \mathrm{H}), 1.94-1.49(\mathrm{~m}, 6 \mathrm{H}) ;{ }^{13} \mathrm{C}$ NMR $\left(150 \mathrm{MHz}, \mathrm{CDCl}_{3}\right) \delta 172.99,172.85,145.93$, $145.81,138.57,138.43,131.68,131.64,128.42,127.98,126.84,126.72,122.09,121.88,99.92$, $96.90,79.94,76.73,62.72,62.60,52.45,52.39,46.90,46.87,38.40,35.67,30.99,30.90,29.87$, 
25.63, 19.55, 19.44; IR (thin film, KBr) $v_{\max }$ 2936, 1737, 1640, 1471, 1200, $1034 \mathrm{~cm}^{-1}$; HRMS

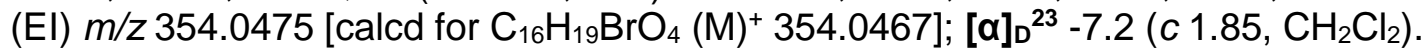

((1S,3R)-6-Bromo-3-((tetrahydro-2H-pyran-2-yl)oxy)-2,3-dihydro-1H-inden-1-yl)methanol

(SI.15a+b) In a $500 \mathrm{~mL}$ 2-neck flask with stir bar, SI.14a+b (1.0 equiv.) from the previous step was added and dissolved in anhydrous $\mathrm{Et}_{2} \mathrm{O}(122 \mathrm{~mL}, 0.2 \mathrm{M})$. The solution was cooled to $0{ }^{\circ} \mathrm{C}$ in an ice/water bath. Under a positive pressure of $\mathrm{N}_{2}$, LAH powder (1.11 g, 1.2 equiv.) was added to the reaction flask. The reaction was stirred at $0{ }^{\circ} \mathrm{C}$ for 3 hours, at which time TLC $(30 \%$ EtOAc in hexanes) indicated complete consumption of starting material. The reaction was quenched with the Fieser \& Fieser workup ${ }^{16}\left(1.11 \mathrm{~mL} \mathrm{H}_{2} \mathrm{O}, 1.11 \mathrm{~mL} 20 \% \mathrm{NaOH}(\mathrm{w} / \mathrm{v})\right.$, followed by $3.33 \mathrm{~mL} \mathrm{H}_{2} \mathrm{O}$ ). The reaction was then warmed to room temperature and $\mathrm{MgSO}_{4}$ was added. The mixture was allowed to stir for 15 minutes. After this time, the solid was filtered and washed thoroughly with $\mathrm{Et}_{2} \mathrm{O}(400 \mathrm{~mL})$. The filtrate was then concentrated in vacuo to a clear oil which was purified by flash column chromatography (25\% to $35 \%$ EtOAc/hexanes) to give the product SI.15a+b as a clear oil. SI.15a+b was an inseparable 1:1 diastereomeric mixture.

${ }^{1} \mathrm{H}$ NMR $\left(500 \mathrm{MHz}, \mathrm{CDCl}_{3}\right) \delta 7.60(\mathrm{~s}, 0.5 \mathrm{H}), 7.49(\mathrm{~s}, 0.5 \mathrm{H}), 7.46-7.39(\mathrm{~m}, 1 \mathrm{H}), 7.22(\mathrm{dd}, J=$ $12.9,8.1 \mathrm{~Hz}, 1 \mathrm{H}), 5.21$ (dd, $J=6.6,4.1 \mathrm{~Hz}, 0.5 \mathrm{H}), 5.09(\mathrm{dd}, J=6.6,3.2 \mathrm{~Hz}, 0.5 \mathrm{H}), 4.91-4.83$ $(\mathrm{m}, 1 \mathrm{H}), 3.98-3.82(\mathrm{~m}, 2 \mathrm{H}), 3.63-3.58(\mathrm{~m}, 1 \mathrm{H}), 3.29-3.24(\mathrm{~m}, 1 \mathrm{H}), 2.65-2.54(\mathrm{~m}, 1 \mathrm{H}), 2.08$ $-2.01(\mathrm{~m}, 0.5 \mathrm{H}), 1.96-1.47(\mathrm{~m}, 7.5 \mathrm{H}) ;{ }^{13} \mathrm{C}$ NMR $\left(150 \mathrm{MHz}, \mathrm{CDCl}_{3}\right) \delta$ 146.10, 145.38, 143.59, 142.96, 132.11, 131.92, 128.93, 128.66, 128.37, 126.46, 125.99, 125.92, 121.37, 121.03, 97.79, $97.11,78.47,77.71,74.37,66.07,66.00,65.49,62.88,62.43,45.40,45.05,44.95,39.43,37.98$, 36.10, 31.01, 30.80, 25.60, 25.57, 19.60, 19.32 IR (thin film, KBr) $V_{\max } 3433$, 2952, 1645, 1474, 1340, 1138, $1018 \mathrm{~cm}^{-1}$; HRMS (EI) $\mathrm{m} / z 326.0498$ [calcd for $\mathrm{C}_{15} \mathrm{H}_{19} \mathrm{BrO}_{3}(\mathrm{M})^{+} 326.0518$ ].

\section{2-(((1R,3S)-6-Bromo-3-(iodomethyl)-2,3-dihydro-1H-inden-1-yl)oxy)tetrahydro-2H-pyran}

(Sl.16a+b) In a $500 \mathrm{~mL}$ round-bottomed flask with stir bar, Sl.15a+b (1.0 equiv.) from the previous step was dissolved in THF (122 mL, $0.2 \mathrm{M})$. To the stirring solution was added $\mathrm{PPh}_{3}$ (8.33 g, 1.3 equiv.) and imidazole ( $2.16 \mathrm{~g}, 1.3$ equiv.) at room temperature. The reaction was then cooled to $0{ }^{\circ} \mathrm{C}$ in an ice/water bath. A solution of iodine $(8.06 \mathrm{~g}, 1.3$ equiv.) in THF (32 mL, $1.0 \mathrm{M}$ ) was then added dropwise to the stirring reaction mixture via syringe over 15 minutes. The reaction was then warmed to room temperature and allowed to stir for 2 hours. At this time, TLC (30\% EtOAc/hexanes) indicated complete consumption of starting material. A saturated aq. solution of $\mathrm{Na}_{2} \mathrm{~S}_{2} \mathrm{O}_{3}(125 \mathrm{~mL})$ was then added and the aqueous layer was extracted with $\mathrm{Et}_{2} \mathrm{O}(3$ $x 150 \mathrm{~mL}$ ). The organic layers were combined, dried over $\mathrm{Na}_{2} \mathrm{SO}_{4}$, and concentrated in vacuo to an oil. The product was purified by flash column chromatography (10\% EtOAc/hexanes) to give the product SI.16a+b as a clear oil $(9.18 \mathrm{~g}, 86 \%$ over 3 steps). SI.16a+b was an inseparable 1:1 diastereomeric mixture.

${ }^{1} \mathbf{H}$ NMR $\left(500 \mathrm{MHz}, \mathrm{CDCl}_{3}\right) \delta 7.59(\mathrm{~s}, 0.5 \mathrm{H}), 7.46(\mathrm{~s}, 0.5 \mathrm{H}), 7.42(\mathrm{~d}, J=8.0 \mathrm{~Hz}, 1 \mathrm{H}), 7.17(\mathrm{dd}, J$ $=22.5,8.1 \mathrm{~Hz}, 1 \mathrm{H}), 5.19(\mathrm{t}, J=6.2 \mathrm{~Hz}, 0.5 \mathrm{H}), 5.02(\mathrm{t}, J=6.2 \mathrm{~Hz}, 0.5 \mathrm{H}), 4.90-4.84(\mathrm{~m}, 1 \mathrm{H})$, $4.00-3.93(\mathrm{~m}, 1 \mathrm{H}), 3.62-3.55(\mathrm{~m}, 2 \mathrm{H}), 3.36-3.25(\mathrm{~m}, 1 \mathrm{H}), 2.72(\mathrm{tt}, J=13.3,6.8 \mathrm{~Hz}, 1 \mathrm{H})$, $2.03-1.98(\mathrm{~m}, 0.5 \mathrm{H}), 1.88-1.74(\mathrm{~m}, 3.5 \mathrm{H}), 1.67-1.53(\mathrm{~m}, 4 \mathrm{H}) ;{ }^{13} \mathbf{C} \mathbf{N M R}\left(125 \mathrm{MHz} \mathrm{CDCl}_{3}\right) \delta$ $146.26,146.17,143.11,142.88,131.65,131.63,128.93,128.53,125.90,125.52,121.79$, 121.54, 99.16, 97.20, 78.78, 76.61, 62.75, 44.95, 44.74, 42.67, 40.71, 31.11, 30.97, 25.63, 19.62, 19.59, 11.14, 11.11; LRMS (ESI) $\mathrm{m} / \mathrm{z} 459.1$ [calcd for $\mathrm{C}_{15} \mathrm{H}_{18} \mathrm{BrlO}_{2} \mathrm{Na}(\mathrm{M}+\mathrm{Na})^{+}$458.9]. IR (thin film, KBr) $v_{\max } 2939,2849,1594,1470,1410,1338,1258,1200,1167,1124,1076,1034$, $989,909,869,815 \mathrm{~cm}^{-1}$. 

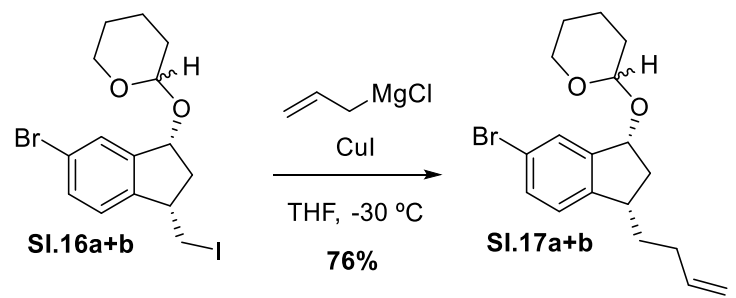

2-(((1R,3S)-6-Bromo-3-(but-3-en-1-yl)-2,3-dihydro-1H-inden-1-yl)oxy)tetrahydro-2H-pyran (SI.17a+b) In a $500 \mathrm{~mL}$ round-bottomed with stir bar, SI.16a+b (9.18 g, 1.0 equiv.) and Cul (2.0 $\mathrm{g}, 0.5$ equiv.) were added and the flask was capped with a septum. To the flask was added anhydrous THF (105 mL, $0.2 \mathrm{M})$ and the heterogeneous mixture was cooled to $-30{ }^{\circ} \mathrm{C}$ in a xylenes/dry ice bath. Once equilibrated to $-30^{\circ} \mathrm{C}$, allylmagnesium chloride in THF $(21.0 \mathrm{~mL}, 2.0$ equiv., 2.0 M) was added dropwise over 10 minutes via syringe. The mixture was allowed to stir at $-30{ }^{\circ} \mathrm{C}$ for 30 minutes, followed by warming to room temperature. After an additional hour of stirring, TLC (10\% EtOAc/hexanes) indicated complete consumption of starting material. The reaction was cooled to $0{ }^{\circ} \mathrm{C}$ and quenched with brine $(75 \mathrm{~mL})$ and $33 \% \mathrm{w} / \mathrm{v}$ aqueous $\mathrm{NH}_{4} \mathrm{OH}(75$ $\mathrm{mL})$. The aqueous layer was extracted with $\mathrm{Et}_{2} \mathrm{O}(3 \times 150 \mathrm{~mL})$ and the organic layers were combined, dried over $\mathrm{Na}_{2} \mathrm{SO}_{4}$, and concentrated in vacuo to an oil. The product was purified by flash column chromatography (5\% EtOAc/hexanes) to give the product $\mathbf{S I . 1 7} \mathbf{a}+\mathbf{b}$ as a clear oil (5.62 $\mathrm{g}, 76 \%$ yield). SI.17a+b was an inseparable 1:1 diastereomeric mixture.

${ }^{1} \mathrm{H}$ NMR $\left(500 \mathrm{MHz}, \mathrm{CDCl}_{3}\right) \delta 7.58(\mathrm{~s}, 0.5 \mathrm{H}), 7.44(\mathrm{~s}, 0.5 \mathrm{H}), 7.37(\mathrm{dd}, J=8.0,1.5 \mathrm{~Hz}, 1 \mathrm{H}), 7.15-$ $7.04(\mathrm{~m}, 1 \mathrm{H}), 5.86$ (dddd, $J=16.9,10.2,6.6,6.6 \mathrm{~Hz}, 1 \mathrm{H}), 5.22(\mathrm{dd}, J=6.9,6.9 \mathrm{~Hz}, 0.5 \mathrm{H}), 5.10$ $-4.96(\mathrm{~m}, 2.5 \mathrm{H}), 4.90(\mathrm{t}, J=3.6 \mathrm{~Hz}, 0.5 \mathrm{H}), 4.85(\mathrm{t}, J=3.6 \mathrm{~Hz}, 0.5 \mathrm{H}), 4.05-3.93(\mathrm{~m}, 1 \mathrm{H}), 3.62$ - $3.56(\mathrm{~m}, 1 \mathrm{H}), 2.99-2.90(\mathrm{~m}, 1 \mathrm{H}), 2.73-2.66(\mathrm{~m}, 1 \mathrm{H}), 2.25-2.09(\mathrm{~m}, 2 \mathrm{H}), 2.07-1.98(\mathrm{~m}$, $1 \mathrm{H}), 1.95-1.50(\mathrm{~m}, 8 \mathrm{H}) ;{ }^{13} \mathrm{C}$ NMR $\left(125 \mathrm{MHz}, \mathrm{CDCl}_{3}\right) \delta 146.14,146.08,145.47,145.38,138.60$, $138.51,131.17,128.03,127.65,125.42,125.19,120.71,120.49,115.09,115.04,100.05$, 96.85, 80.42, 77.34, 62.93, 62.63, 41.70, 41.22, 41.11, 39.47, 34.58, 34.55, 31.85, 31.80, 31.14, 31.10, 25.67, 25.65, 19.83, 19.60; LRMS (ESI) $\mathrm{m} / \mathrm{z} 351.3$ [calcd for $\mathrm{C}_{18} \mathrm{H}_{24} \mathrm{BrO}_{2}(\mathrm{M}+\mathrm{H})^{+}$351.1]. IR (thin film, KBr) $V_{\max } 3073,2925,1639,1597,1470,1338,1200,1133,1063,1035,993,910,869,813$ $\mathrm{cm}^{-1}$.

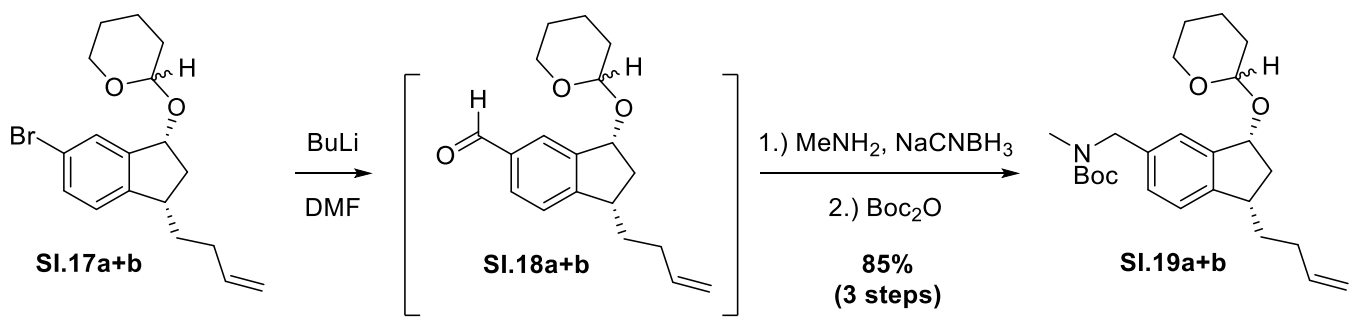

Tert-butyl (((1R,3S)-3-(but-3-en-1-yl)-1-((tetrahydro-2H-pyran-2-yl)oxy)-2,3-dihydro-1H-inden-5-yl)methyl)(methyl)carbamate (SI.19a+b) In an oven-dried $250 \mathrm{~mL}$ round-bottomed flask with stir bar, SI.17a+b (5.62 g, 1.0 equiv.) was added and the flask was capped with a septum. To the flask was added anhydrous THF $(53.3 \mathrm{~mL}, 0.3 \mathrm{M})$ and the solution was cooled to $-78^{\circ} \mathrm{C}$ in an acetone/dry ice bath. Once equilibrated, $n$-butyllithium in hexanes (7.04 mL, 1.1 equiv., 2.5 M) was added dropwise via syringe over 10 minutes. The reaction was allowed to stir for 15 minutes before addition of DMF (1.48 mL, 1.2 equiv.). The reaction was allowed to stir for 15 minutes and was warmed to room temperature. The reaction was allowed to stir for an additional 30 minutes at room temperature when TLC (10\% EtOAc/hexanes) indicated complete consumption of starting material. The reaction was quenched with brine $(75 \mathrm{~mL})$ and the aqueous layer was extracted with EtOAc $(3 \times 75 \mathrm{~mL})$. The organic layers were combined, dried 
over $\mathrm{Na}_{2} \mathrm{SO}_{4}$, and concentrated in vacuo to give crude $\mathbf{S I . 1 8 a + b}$ as a clear oil. This material was used in the next step without further purification.

To a solution of crude SI.18a+b in $\mathrm{MeOH} / \mathrm{CH}_{2} \mathrm{Cl}_{2}(5: 1$ ratio, $20 \mathrm{~mL}, 0.85 \mathrm{M})$ was added $40 \mathrm{wt} \%$ aqueous $\mathrm{MeNH}_{2}\left(4.71 \mathrm{~mL}, 3.4\right.$ equiv) at $0{ }^{\circ} \mathrm{C}$. The resulting solution was stirred at $0{ }^{\circ} \mathrm{C}$ for 1 hour, followed by the addition of $\mathrm{NaBH}_{4}(1.57 \mathrm{~g}, 2.6$ equiv) in one portion. The resulting suspension was continued to stir at $0 \stackrel{\circ}{ } \mathrm{C}$ for 2 hours, or until TLC (10\% EtOAc/hexanes) indicated complete consumption of starting material. The reaction mixture was then treated with an aqueous saturated solution of $\mathrm{NaHCO}_{3}(50 \mathrm{~mL})$. The resulting mixture was allowed to warm to room temperature and extracted with $\mathrm{CH}_{2} \mathrm{Cl}_{2}(3 \times 50 \mathrm{~mL})$. The organic layers were combined, dried over $\mathrm{Na}_{2} \mathrm{SO}_{4}$, and concentrated in vacuo to give an oil. This was dissolved in $\mathrm{CH}_{2} \mathrm{Cl}_{2}$ (16 $\mathrm{mL}$ ) and this solution was cooled to $0{ }^{\circ} \mathrm{C}$, to which a solution of $\mathrm{Boc}_{2} \mathrm{O}$ (4.04 mL, 1.05 equiv) in $\mathrm{CH}_{2} \mathrm{Cl}_{2}(7.65 \mathrm{~mL}, 2.3 \mathrm{M})$ was added dropwise. The reaction mixture was warmed to room temperature and stirred for 1 hour. The solvent was then concentrated in vacuo to give crude Sl.19a+b as an oil, which was purified by flash column chromatography (10\% EtOAc/hexanes) to give the product SI.19a+b as a clear oil (5.65 g, 85\% over 3 steps). SI.19a+b was an inseparable 1:1 diastereomeric mixture.

${ }^{1} \mathrm{H}$ NMR $\left(500 \mathrm{MHz}, \mathrm{CDCl}_{3}\right) \delta 7.32(\mathrm{~s}, 0.5 \mathrm{H}), 7.21-7.06(\mathrm{~m}, 2.5 \mathrm{H}), 5.87$ (dddd, $J=16.9,11.3$, 6.4, $6.4 \mathrm{~Hz}, 1 \mathrm{H}), 5.24(\mathrm{t}, J=6.8 \mathrm{~Hz}, 0.5 \mathrm{H}), 5.10-4.96(\mathrm{~m}, 2.5 \mathrm{H}), 4.93(\mathrm{t}, J=3.5 \mathrm{~Hz}, 0.5 \mathrm{H}), 4.88$ $(\mathrm{t}, J=3.5 \mathrm{~Hz}, 0.5 \mathrm{H}), 4.41(\mathrm{~s}, 2 \mathrm{H}), 4.07-4.02(\mathrm{~m}, 0.5 \mathrm{H}), 4.00-3.96(\mathrm{~m}, 0.5 \mathrm{H}), 3.61-3.55(\mathrm{~m}$, $1 \mathrm{H}), 3.05-2.94(\mathrm{~m}, 1 \mathrm{H}), 2.83-2.67(\mathrm{~m}, 4 \mathrm{H}), 2.27-2.11(\mathrm{~m}, 2 \mathrm{H}), 2.10-1.99(\mathrm{~m}, 1 \mathrm{H}), 1.93-$ $1.46(\mathrm{~m}, 17 \mathrm{H}) ;{ }^{13} \mathrm{C}$ NMR $\left(125 \mathrm{MHz}, \mathrm{CDCl}_{3}\right) \delta 145.67,138.81,138.72,136.96,136.76,123.83$, 123.65, 114.88, 114.82, 100.03, 96.57, 62.91, 62.43, 52.69, 41.34, 41.25, 39.46, 34.80, 33.98, 31.96, 31.91, 31.15, 28.62, 25.71, 25.66, 19.89, 19.52; IR (thin film, KBr) $\mathrm{v}_{\max } 3075,2927,2868$, 1697, 1481, 1453, 1391, 1365, 1319, 1239, 1200, 1174, 1136, 1077, 1062, 1034, 998, 970, 906 $\mathrm{cm}^{-1}$; HRMS (ESI) $\mathrm{m} / \mathrm{z} 438.2643$ [calcd for $\mathrm{C}_{25} \mathrm{H}_{37} \mathrm{NO}_{4} \mathrm{Na}(\mathrm{M}+\mathrm{Na})^{+} 438.2620$ ]; [a] ${ }_{\mathrm{D}}^{23}-7.9$ (c 1.02 , $\mathrm{CH}_{2} \mathrm{Cl}_{2}$ ).

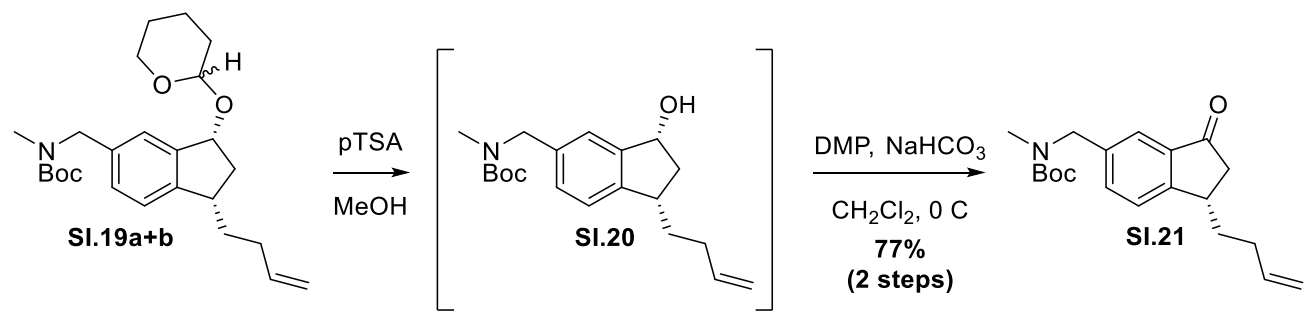

Tert-butyl (S)-((3-(but-3-en-1-yl)-1-oxo-2,3-dihydro-1H-inden-6-yl)methyl)(methyl) carbamate (SI.21) In a $500 \mathrm{~mL}$ round-bottomed flask with stir bar, pTSA (569.1 mg, 0.22 equiv) was added to a solution of SI.19a+b (5.65 g, 1.0 equiv.) in $\mathrm{MeOH}(227 \mathrm{~mL}, 0.06 \mathrm{M}$ ) at room temperature. The resulting solution was stirred at room temperature for 1 hour, at which time TLC (20\% EtOAc/hexanes) indicated complete consumption of starting material. The reaction mixture was then treated with a saturated aq. solution of $\mathrm{NaHCO}_{3}(100 \mathrm{~mL})$ and extracted with EtOAc $(3 \times 100 \mathrm{~mL})$. The organic layers were combined, dried over $\mathrm{Na}_{2} \mathrm{SO}_{4}$, and concentrated in vacuo to give crude SI.20 as an oil. This residue was taken up in anhydrous $\mathrm{CH}_{2} \mathrm{Cl}_{2}(123 \mathrm{~mL}$, $0.1 \mathrm{M}$ ) and solid $\mathrm{NaHCO}_{3}(4.14 \mathrm{~g}, 4.0$ equiv) was added at room temperature in a $500 \mathrm{~mL}$ round-bottomed flask. The resulting suspension was cooled to at $0{ }^{\circ} \mathrm{C}$ in an ice/water bath and DMP (7.84 g, 1.5 equiv) was then added in one portion. The reaction was then warmed to room temperature and was allowed to stir for 1 hour, at which time TLC (20\% EtOAc/hexanes) indicated complete consumption of starting material. The reaction mixture was then treated with a saturated aq. solution of $\mathrm{Na}_{2} \mathrm{~S}_{2} \mathrm{O}_{3}(100 \mathrm{~mL})$. The resulting mixture was extracted with $\mathrm{CH}_{2} \mathrm{Cl}_{2}$ 
$(3 \times 100 \mathrm{~mL})$. The organic layers were combined, dried over $\mathrm{Na}_{2} \mathrm{SO}_{4}$, and concentrated in vacuo to give an oil, which was purified by flash column chromatography (15\% EtOAc/hexanes) to give SI.21 as a clear oil (3.47 g, 77\% yield, 2 steps).

${ }^{1} \mathrm{H}$ NMR $\left(500 \mathrm{MHz}, \mathrm{CDCl}_{3}\right) \delta 7.60-7.43(\mathrm{~m}, 3 \mathrm{H}), 5.84$ (dddd, $\left.J=16.9,10.2,6.6,6.6 \mathrm{~Hz}, 1 \mathrm{H}\right)$, $5.07-5.00(\mathrm{~m}, 2 \mathrm{H}), 4.46(\mathrm{~s}, 2 \mathrm{H}), 3.39-3.34(\mathrm{~m}, 1 \mathrm{H}), 2.90-2.78(\mathrm{~m}, 4 \mathrm{H}), 2.38(\mathrm{dd}, J=19.0$, $3.0 \mathrm{~Hz}, 1 \mathrm{H}), 2.21-2.12(\mathrm{~m}, 2 \mathrm{H}), 2.05-1.98(\mathrm{~m}, 1 \mathrm{H}), 1.58(\mathrm{td}, J=14.6,8.8 \mathrm{~Hz}, 1 \mathrm{H}), 1.48(\mathrm{~s}$, 9H); ${ }^{13} \mathrm{C}$ NMR $\left(150 \mathrm{MHz}, \mathrm{CDCl}_{3}\right) \delta 205.96,157.87,156.13,138.07,137.73,137.09,134.42$, 133.85, 125.85, 122.18, 115.38, 79.90, 52.30, 51.54, 43.31, 37.46, 35.31, 34.08, 31.78, 28.46; IR (thin film, KBr) $\mathbf{V}_{\max } 3075,2975,2926,2360,1714,1697,1640,1617,1579,1486,1453$, 1391, 1365, 1286, 1239, 1146, 1112, 1044, 980, $916 \mathrm{~cm}^{-1}$; HRMS (ESI) m/z 352.1876 [calcd for $\left.\mathrm{C}_{20} \mathrm{H}_{27} \mathrm{NO}_{3} \mathrm{Na}(\mathrm{M}+\mathrm{Na})^{+} 352.1889\right] ;[\alpha]_{\mathrm{D}}^{23}+9.3\left(c 1.14, \mathrm{CH}_{2} \mathrm{Cl}_{2}\right)$.

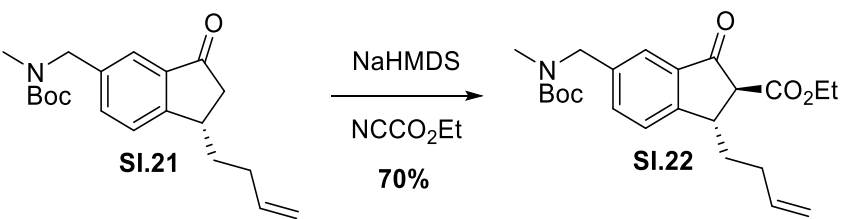

Ethyl (2S,3S)-3-(but-3-en-1-yl)-6-(((tert-butoxycarbonyl)(methyl)amino)methyl)-1-oxo-2,3dihydro-1H-indene-2-carboxylate (SI.22) In an oven dried $250 \mathrm{~mL}$ round-bottomed flask with stir bar, SI.21 (3.47 g, 1.0 equiv.) was dissolved in anhydrous THF (101 mL, $0.1 \mathrm{M})$. This solution was then cooled to $-78{ }^{\circ} \mathrm{C}$ in a dry ice/acetone bath. A solution of NaHMDS in THF (21.0 mL, $1.0 \mathrm{M}, 2.1$ equiv.) was then added dropwise to the stirring solution. After 30 minutes, Mander's reagent (1.32 $\mathrm{mL}, 1.3$ equiv.) was added dropwise. The reaction was allowed to stir for an additional hour. The flask was warmed to room temperature and was quenched with brine $(100 \mathrm{~mL})$. The aqueous layer was then extracted with EtOAc $(3 \times 100 \mathrm{~mL})$. The organic layers were combined, dried over $\mathrm{Na}_{2} \mathrm{SO}_{4}$, and concentrated in vacuo to give an oil. The oil was then purified by flash column chromatography (15\% EtOAc/hexanes) to give SI.22 as a yellow oil (2.94 g, 70\% yield).

${ }^{1} \mathbf{H}$ NMR $\left(500 \mathrm{MHz}, \mathrm{CDCl}_{3}\right) \delta 7.59-7.47(\mathrm{~m}, 3 \mathrm{H}), 5.83$ (dddd, $\left.J=16.9,10.2,6.5,6.5 \mathrm{~Hz}, 1 \mathrm{H}\right)$, $5.07-5.00(\mathrm{~m}, 2 \mathrm{H}), 4.46(\mathrm{~s}, 2 \mathrm{H}), 4.24(\mathrm{q}, J=7.1,2 \mathrm{H}), 3.78-3.72(\mathrm{~m}, 1 \mathrm{H}), 3.38(\mathrm{~d}, J=3.9 \mathrm{~Hz}$, $1 \mathrm{H}), 2.86-2.78(\mathrm{~m}, 3 \mathrm{H}), 2.24-2.04(\mathrm{~m}, 3 \mathrm{H}), 1.70-1.60(\mathrm{~m}, 1 \mathrm{H}), 1.48(\mathrm{~s}, 9 \mathrm{H}), 1.30(\mathrm{t}, J=7.1$ $\mathrm{Hz}, 3 \mathrm{H}) ;{ }^{13} \mathrm{C}$ NMR $\left(125 \mathrm{MHz}, \mathrm{CDCl}_{3}\right) \delta 199.11,169.40,156.63,146.82,138.82,137.45,135.59$, $125.85,123.16,115.90,114.54,80.15,61.86,60.68,60.23,43.61,42.48,37.63,34.69,34.30$, 31.74, 29.86, 28.86, 28.64, 28.61, 14.65, 14.37; IR (thin film, KBr) $v_{\max } 3076,2977,2929,2360$, 1741, 1713, 1481, 1392, 1366, 1248, 1148, 1022, $877 \mathrm{~cm}^{-1}$; HRMS (ESI) $\mathrm{m} / \mathrm{z} 424.2108$ [calcd

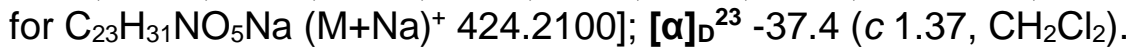

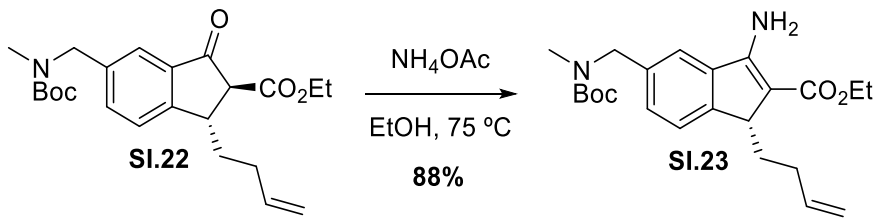

Ethyl (R)-3-amino-1-(but-3-en-1-yl)-6-(((tert-butoxycarbonyl)(methyl)amino)methyl)-1Hind-ene-2-carboxylate (SI.23) In a $100 \mathrm{~mL}$ round-bottomed flask with stir bar, SI.22 (2.91 g, 1.0 equiv.) and ammonium acetate (5.58 g, 10 equiv.) were dissolved in ethanol $(18.1 \mathrm{~mL}, 0.4 \mathrm{M})$ at room temperature. The flask was fitted with a reflux condenser and heated to $75{ }^{\circ} \mathrm{C}$ in an oil bath. After 16 hours, TLC indicated complete consumption of starting material (20\% 
EtOAc/hexanes). The reaction was then cooled to room temperature and quenched with aq. sat. $\mathrm{NaHCO}_{3}(40 \mathrm{~mL})$ and the aqueous layer was extracted with $\mathrm{CH}_{2} \mathrm{Cl}_{2}(3 \times 40 \mathrm{~mL})$. The organic layers were combined, dried over $\mathrm{Na}_{2} \mathrm{SO}_{4}$, and concentrated in vacuo to give a brown oil, which was purified by flash column chromatography (15\% EtOAc/hexanes) to give SI.23 as a yellow oil $(2.56 \mathrm{~g}, 88 \%$ yield).

${ }^{1} \mathbf{H}$ NMR $\left(500 \mathrm{MHz} \mathrm{CDCl}_{3}\right) \delta 7.41(\mathrm{~d}, J=7.7 \mathrm{~Hz}, 1 \mathrm{H}), 7.28-7.16(\mathrm{~m}, 2 \mathrm{H}), 5.98(\mathrm{brs}, 2 \mathrm{H}), 5.70$ (dddd, $J=16.9,10.2,6.6,6.6 \mathrm{~Hz}, 1 \mathrm{H}), 4.90-4.82(\mathrm{~m}, 2 \mathrm{H}), 4.48(\mathrm{~s}, 2 \mathrm{H}), 4.38-4.28(\mathrm{~m}, 1 \mathrm{H})$, $4.25-4.19(\mathrm{~m}, 1 \mathrm{H}), 3.82(\mathrm{dd}, J=4.7,4.7 \mathrm{~Hz}, 1 \mathrm{H}), 2.83(\mathrm{~s}, 3 \mathrm{H}), 2.19-2.08(\mathrm{~m}, 2 \mathrm{H}), 1.86-$ $1.79(\mathrm{~m}, 1 \mathrm{H}), 1.61-1.43(\mathrm{~m}, 10 \mathrm{H}), 1.34(\mathrm{t}, J=7.1 \mathrm{~Hz}, 3 \mathrm{H}) ;{ }^{13} \mathbf{C}$ NMR $\left(125 \mathrm{MHz}, \mathrm{CDCl}_{3}\right) \delta$ $167.93,156.26,147.94,139.48,139.22$, 136.97, 126.38, 125.79, 122.82, 118.96, 114.16, 101.76, 79.99, 59.10, 53.04, 52.30, 45.37, 34.29, 30.59, 28.81, 28.63, 14.89; IR (thin film, $\mathrm{KBr}$ ) $\mathrm{V}_{\max } 3441,3337,3073,2976,2929,2360,1663,1628,1540,1453,1392,1366,1259,1146$,

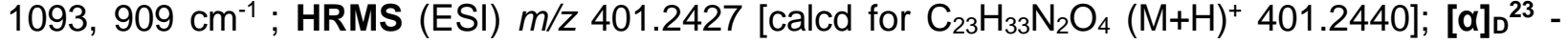
44.5 (c $0.83, \mathrm{CH}_{2} \mathrm{Cl}_{2}$ ).

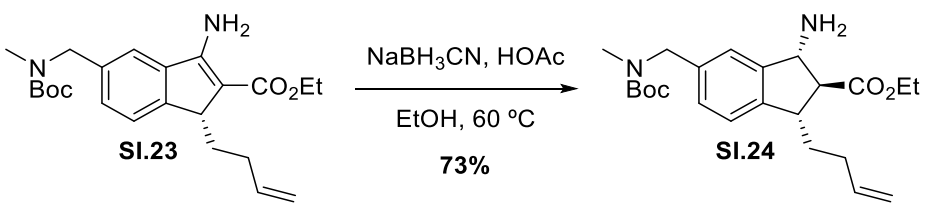

Ethyl (1R,2S,3S)-1-amino-3-(but-3-en-1-yl)-6-(((tert-butoxycarbonyl)(methyl)amino)methyl)-2,3-dihydro-1H-indene-2-carboxylate (SI.24) In a $100 \mathrm{~mL}$ round-bottomed flask with stir bar, SI.23, (2.56 g, 1.0 equiv.), $\mathrm{NaBH}_{3} \mathrm{CN}$ (2.01 g, 6 equiv.), and $\mathrm{AcOH}$ (2.92 mL, 8 equiv.) were dissolved in ethanol $(21.3 \mathrm{~mL}, 0.3 \mathrm{M})$ at room temperature. The flask was sealed with a septum and fitted with a reflux condenser. The reaction was heated to $60^{\circ} \mathrm{C}$ in an oil bath and allowed to stir overnight. After 16 hours, TLC indicated complete consumption of starting material $(50 \%$ EtOAc/hexanes) with the product staining well in $\mathrm{KMnO}_{4}$. The reaction was then cooled to room temperature and quenched with $1 \mathrm{M} \mathrm{NaOH}(20 \mathrm{~mL})$ and the aqueous layer was extracted with $\mathrm{CH}_{2} \mathrm{Cl}_{2}(3 \times 40 \mathrm{~mL})$. The organic layers were combined, dried over $\mathrm{Na}_{2} \mathrm{SO}_{4}$, and concentrated in vacuo to give an oil, which was purified by flash column chromatography $(50 \%$ to $100 \%$ EtOAc/hexanes) to give SI.24 as a yellow oil (1.88 g, 73\% yield).

${ }^{1} \mathbf{H}$ NMR $\left(500 \mathrm{MHz}, \mathrm{CDCl}_{3}\right) \delta 7.24-7.08$ (m, 3H), 5.85 (dddd, $\left.J=16.8,10.3,6.4,6.4 \mathrm{~Hz}, 1 \mathrm{H}\right)$, $5.06-5.02(\mathrm{~m}, 1 \mathrm{H}), 5.00-4.97(\mathrm{~m}, 1 \mathrm{H}), 4.48(\mathrm{~d}, J=8.5 \mathrm{~Hz}, 1 \mathrm{H}), 4.41(\mathrm{~s}, 2 \mathrm{H}), 4.28-4.21(\mathrm{~m}$, $2 \mathrm{H}), 3.46-3.41(\mathrm{~m}, 1 \mathrm{H}), 2.81(\mathrm{~s}, 3 \mathrm{H}), 2.58(\mathrm{dd}, J=8.9,8.9 \mathrm{~Hz}, 1 \mathrm{H}), 2.18-2.03(\mathrm{~m}, 3 \mathrm{H}), 1.91$ $(\mathrm{s}, 2 \mathrm{H}), 1.77-1.66(\mathrm{~m}, 1 \mathrm{H}), 1.48(\mathrm{~s}, 9 \mathrm{H}), 1.32(\mathrm{t}, J=7.1 \mathrm{~Hz}, 3 \mathrm{H}) ;{ }^{13} \mathbf{C}$ NMR $\left(125 \mathrm{MHz}, \mathrm{CDCl}_{3}\right) \delta$ $174.61,155.98,144.91,143.04,138.43,137.56,127.70,127.23,124.21,123.59,122.60$, 115.03, 79.89, 63.46, 61.00, 60.76, 57.90, 52.72, 52.01, 44.97, 44.29, 34.11, 33.87, 33.48, 31.49, 31.00, 28.66, 14.52; IR (thin film, KBr) $v_{\max } 3381,3074,2976,2928,2360,1727,1694$, 1482, 1453, 1392, 1366, 1238, 1173, 1031, 911, $877 \mathrm{~cm}^{-1}$; HRMS (ESI) m/z 403.2595 [calcd for $\left.\mathrm{C}_{23} \mathrm{H}_{35} \mathrm{~N}_{2} \mathrm{O}_{4}(\mathrm{M}+\mathrm{H})^{+} 403.2597\right] ;[\alpha]_{D}{ }^{23}-9.5\left(c 1.11, \mathrm{CH}_{2} \mathrm{Cl}_{2}\right)$.

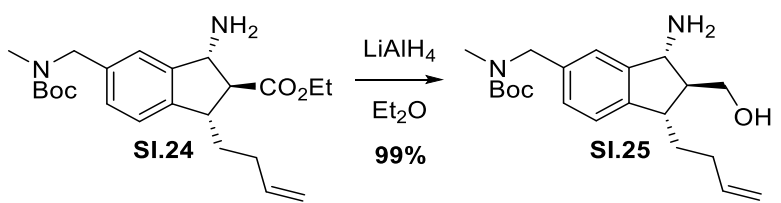

Tert-butyl (((1R,2S,3S)-1-amino-3-(but-3-en-1-yl)-2-(hydroxymethyl)-2,3-dihydro-1H-inden6-yl)methyl)(methyl)carbamate (SI.25) In a $200 \mathrm{~mL}$ round-bottomed flask with stir bar, SI.24 (1.88 g, 1.0 equiv.) was added and dissolved in anhydrous $\mathrm{Et}_{2} \mathrm{O}(23.4 \mathrm{~mL}, 0.2 \mathrm{M})$. The solution 
was then cooled to $0{ }^{\circ} \mathrm{C}$ in an ice/water bath. $\mathrm{LAH}$ powder $(213 \mathrm{mg}, 1.2$ equiv.) was added to the reaction flask. The reaction was stirred at $0{ }^{\circ} \mathrm{C}$ for 2 hours, at which time TLC $(10 \%$ $\mathrm{MeOH} / \mathrm{CH}_{2} \mathrm{Cl}_{2}$ ) indicated complete consumption of starting material. The reaction was quenched with the Fieser \& Fieser workup ${ }^{16}\left(213 \mu \mathrm{L} \mathrm{H} \mathrm{H}_{2} \mathrm{O}, 213 \mu \mathrm{L} 20 \% \mathrm{NaOH}(\mathrm{w} / \mathrm{v})\right.$, followed by $640 \mu \mathrm{L}$ $\mathrm{H}_{2} \mathrm{O}$ ). The reaction was then warmed to room temperature and $\mathrm{MgSO}_{4}$ was added. The mixture was allowed to stir for 30 minutes. After this time, the solid was filtered and washed thoroughly with $\mathrm{Et}_{2} \mathrm{O}(100 \mathrm{~mL})$. The filtrate was then concentrated in vacuo to an oil, which was purified by flash column chromatography $\left(10 \% \mathrm{MeOH} / \mathrm{CH}_{2} \mathrm{Cl}_{2}\right)$ to give SI.25 as a yellow oil (1.68 $\left.\mathrm{g}, 99 \%\right)$.

${ }^{1} \mathrm{H}$ NMR $\left(500 \mathrm{MHz}, \mathrm{CDCl}_{3}\right) \delta 7.32$ (brs, 1H), $7.20-7.06$ (m, 2H), 5.82 (dddd, $J=16.8,10.2,6.5$, $6.5 \mathrm{~Hz}, 1 \mathrm{H}), 5.06-5.02(\mathrm{~m}, 1 \mathrm{H}), 5.00-4.96(\mathrm{~m}, 1 \mathrm{H}), 4.42-4.17(\mathrm{br} \mathrm{m}, 6 \mathrm{H}), 4.18(\mathrm{~d}, J=8.4$ $\mathrm{Hz}, 1 \mathrm{H}), 4.07(\mathrm{dd}, J=6.5,4.0 \mathrm{~Hz}, 1 \mathrm{H}), 3.79-3.75(\mathrm{~m}, 1 \mathrm{H}), 2.77(\mathrm{~s}, 3 \mathrm{H}), 2.31-2.24(\mathrm{~m}, 1 \mathrm{H})$, $2.21-2.12(\mathrm{~m}, 2 \mathrm{H}), 1.92(\mathrm{dq}, J=13.8,7.6,7.1 \mathrm{~Hz}, 1 \mathrm{H}), 1.82-1.74(\mathrm{~m}, 1 \mathrm{H}), 1.45(\mathrm{~s}, 9 \mathrm{H}) ;{ }^{13} \mathrm{C}$ NMR $\left(125 \mathrm{MHz}, \mathrm{CDCl}_{3}\right) \delta 156.35,144.45,143.43,138.44,137.42,127.98,124.72,124.13$, 122.34, 115.38, 115.17, 80.00, 65.38, 60.57, 55.92, 52.66, 52.02, 43.40, 34.21, 32.87, 31.31, 29.88, 28.66, 14.30; IR (thin film, KBr) $v_{\max } 3353,3074,2975,2925,2361,1694,1482,1453$, 1393, 1366, 1302, 1246, 1148, 909, 874, $832 \mathrm{~cm}^{-1}$; HRMS (ESI) $\mathrm{m} / \mathrm{z} 361.2496$ [calcd for $\left.\mathrm{C}_{21} \mathrm{H}_{33} \mathrm{~N}_{2} \mathrm{O}_{3}(\mathrm{M}+\mathrm{H})^{+} 361.2491\right] ;[\alpha]_{D}{ }^{23}-22.9$ ( c $\left.0.93, \mathrm{CH}_{2} \mathrm{Cl}_{2}\right)$.

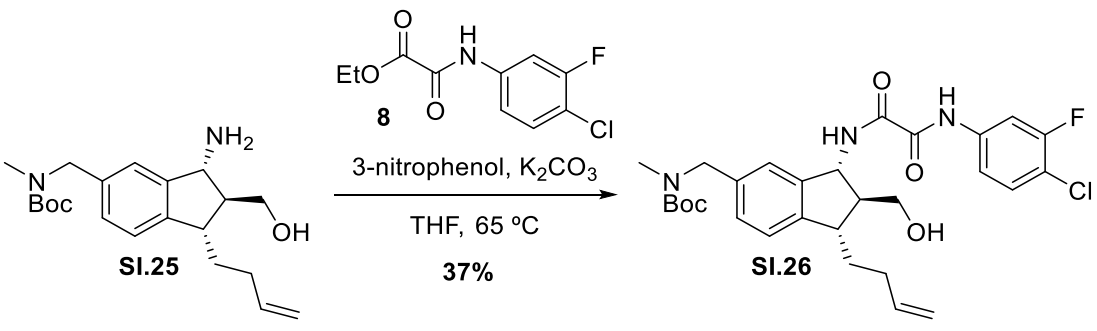

Tert-butyl (((1R,2S,3S)-3-(but-3-en-1-yl)-1-(2-((4-chloro-3-fluorophenyl)amino)-2-oxoacetamido)-2-(hydroxymethyl)-2,3-dihydro-1H-inden-6-yl)methyl)(methyl)carbamate (SI.26) In a $100 \mathrm{~mL}$ round-bottomed flask equipped with a reflux condenser and stir bar, a mixture of SI.25 (1.68 g, 1.0 equiv.), 8 (1.32 g, 1.15 equiv.), 3-nitrophenol (130 mg, 0.2 equiv.), and $\mathrm{K}_{2} \mathrm{CO}_{3}$ (130 mg, 0.2 equiv.) in THF (10 mL, $0.8 \mathrm{M})$ was stirred at $65^{\circ} \mathrm{C}$ for $16 \mathrm{~h}$. The resulting suspension was allowed to cool to room temperature and then treated with $10 \mathrm{wt} \% \mathrm{~K}_{2} \mathrm{CO}_{3}(20 \mathrm{~mL})$. The resulting mixture was further stirred at room temperature for $1 \mathrm{hr}$, and then diluted with EtOAc $(50 \mathrm{~mL})$. The aqueous layer was extracted with EtOAc $(3 \times 50 \mathrm{~mL})$. The organic layers were combined, dried over $\mathrm{Na}_{2} \mathrm{SO}_{4}$, and concentrated in vacuo to give an oil, which was purified by flash column chromatography (50\% to $100 \%$ EtOAc/hexanes) to give $\mathbf{S I . 2 6}$ as a colorless amorphous solid (974 $\mathrm{mg}, 37 \%$ yield).

${ }^{1} \mathrm{H}$ NMR $\left(500 \mathrm{MHz}, \mathrm{CDCl}_{3}\right) \delta 9.45$ (s, 1H), 7.94 (brs, 1H), 7.71 (dd, J=10.5, $\left.2.3 \mathrm{~Hz}, 1 \mathrm{H}\right), 7.38$ (t, $J=8.3 \mathrm{~Hz}, 1 \mathrm{H}), 7.29-7.27(\mathrm{~m}, 1 \mathrm{H}), 7.23-7.19(\mathrm{~m}, 2 \mathrm{H}), 7.10(\mathrm{~s}, 1 \mathrm{H}), 5.84$ (dddd, $J=16.8$, $10.2,6.5,6.5 \mathrm{~Hz}, 1 \mathrm{H}), 5.21(\mathrm{dd}, J=7.2,7.2 \mathrm{~Hz}, 1 \mathrm{H}), 5.07-4.99(\mathrm{~m}, 2 \mathrm{H}), 4.41(\mathrm{~s}, 2 \mathrm{H}), 3.86(\mathrm{dd}$, $J=11.3,3.4 \mathrm{~Hz}, 1 \mathrm{H}), 3.74(\mathrm{dd}, J=9.6,9.6 \mathrm{~Hz}, 1 \mathrm{H}), 2.97-2.80(\mathrm{~m}, 4 \mathrm{H}), 2.27-2.14(\mathrm{~m}, 3 \mathrm{H})$, $1.97-1.90(\mathrm{~m}, 1 \mathrm{H}), 1.81-1.74(\mathrm{~m}, 1 \mathrm{H}), 1.47(\mathrm{~s}, 9 \mathrm{H}) ;{ }^{13} \mathrm{C} \mathrm{NMR}\left(125 \mathrm{MHz}, \mathrm{CDCl}_{3}\right) \delta 160.20$, $158.25\left(\mathrm{~d}, J_{C F}=248.5 \mathrm{~Hz}\right), 157.18,144.97,140.12,138.16,138.14,136.31\left(\mathrm{~d}, J_{C F}=9.7 \mathrm{~Hz}\right)$, 131.06, 128.79, 128.30, 124.73, 123.51, 123.04, $117.52\left(\mathrm{~d}, J_{C F}=18.4 \mathrm{~Hz}\right), 116.23\left(\mathrm{~d}, J_{C F}=3.5\right.$ $\mathrm{Hz}), 115.40,108.70\left(\mathrm{~d}, J_{C F}=26.2 \mathrm{~Hz}\right), 80.08,64.16,58.26,57.70,52.57,51.94,44.39,34.17$, 31.20, 29.88, 28.63; IR (thin film, KBr) $V_{\max } 3353,3287,3075,2975,2926,2248,1671,1594$, 1514, 1427, 1366, 1304, 1243, 1150, 1066, $973 \mathrm{~cm}^{-1}$; HRMS (ESI) $\mathrm{m} / \mathrm{z} 582.2143$ [calcd for $\left.\mathrm{C}_{29} \mathrm{H}_{35} \mathrm{ClFN}_{3} \mathrm{O}_{5} \mathrm{Na}(\mathrm{M}+\mathrm{Na})^{+} 582.2147\right] ;[\alpha]_{\mathrm{D}}^{23}-52.8\left(\mathrm{c} 0.88, \mathrm{CH}_{2} \mathrm{Cl}_{2}\right)$. 


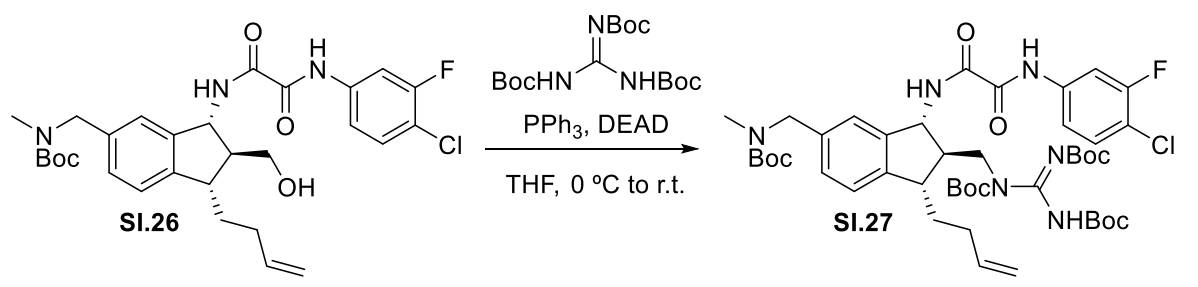

Compound SI.27 In a $200 \mathrm{~mL}$ round-bottomed flask with stir bar, a mixture of SI.26 (974 mg, 1.0 equiv.), $\mathrm{PPh}_{3}$ (730 mg, 1.6 equiv.), and $\mathrm{N}, \mathrm{N}^{\prime}, \mathrm{N}^{\prime}$-tri-Boc-guanidine (2.19 g, 3.5 equiv.) in anhydrous THF (44 mL, $0.04 \mathrm{M})$ was stirred at room temperature until a well-dispersed suspension had formed. This mixture was cooled at $0{ }^{\circ} \mathrm{C}$ and treated with diethyl azodicarboxylate $(410 \mu \mathrm{L}, 1.5$ equiv.) dropwise at such a rate that each drop was only added after the color change resulting from the previous drop had dissipated. After the addition was completed, the reaction was allowed to warm to room temperature and stir for $18 \mathrm{hr}$. TLC (30\% EtOAc/hexanes) indicated complete consumption of starting material at this time. The reaction was then quenched with brine $(50 \mathrm{~mL})$ and the aqueous layer was extracted with EtOAc $(3 \times 50$ $\mathrm{mL}$ ). The organic layers were combined, dried over $\mathrm{Na}_{2} \mathrm{SO}_{4}$, and concentrated in vacuo to give a white solid which was purified by flash column chromatography (20\% EtOAc/hexanes) to give a mixture of SI.27 and N,N',N"-tri-Boc-guanidine. The residue was treated with $\mathrm{Et}_{2} \mathrm{O}(10 \mathrm{~mL})$ and the insoluble material was removed via vacuum filtration. The filtrate was concentrated in vacuo to give SI.27 as an off-white amorphous solid (1.22 g, 78\%).

${ }^{1} \mathbf{H}$ NMR $\left(500 \mathrm{MHz}, \mathrm{CDCl}_{3}\right) \delta 10.31(\mathrm{~s}, 1 \mathrm{H}), 9.28(\mathrm{~s}, 1 \mathrm{H}), 7.80(\mathrm{~d}, J=8.4 \mathrm{~Hz}, 1 \mathrm{H}), 7.71$ (dd, $J=$ 10.6, $2.3 \mathrm{~Hz}, 1 \mathrm{H}), 7.37(\mathrm{t}, J=8.3 \mathrm{~Hz}, 1 \mathrm{H}), 7.23-7.11(\mathrm{~m}, 2 \mathrm{H}), 7.06(\mathrm{~s}, 1 \mathrm{H}), 5.84$ (dddd, $J=$ 16.9, 10.1, 6.5, $6.5 \mathrm{~Hz}, 1 \mathrm{H}), 5.26(\mathrm{dd}, J=8.3,5.6 \mathrm{~Hz}, 1 \mathrm{H}), 5.10-5.06(\mathrm{~m}, 1 \mathrm{H}), 5.01-4.98(\mathrm{~m}$, $1 \mathrm{H}), 4.42(\mathrm{~s}, 2 \mathrm{H}), 4.08-4.01(\mathrm{~m}, 2 \mathrm{H}), 2.91-2.87(\mathrm{~m}, 1 \mathrm{H}), 2.77(\mathrm{~s}, 3 \mathrm{H}), 2.62-2.57(\mathrm{~m}, 1 \mathrm{H})$, $2.26-2.18(\mathrm{~m}, 2 \mathrm{H}), 1.91-1.77(\mathrm{~m}, 2 \mathrm{H}), 1.48(\mathrm{~s}, 36 \mathrm{H}) ;{ }^{13} \mathrm{C}$ NMR $\left(151 \mathrm{MHz}, \mathrm{CDCl}_{3}\right) \delta 159.19$, $158.25\left(\mathrm{~d}, J_{C F}=248.5 \mathrm{~Hz}\right), 157.63,153.59,149.96,144.67,138.43,137.73,136.62\left(\mathrm{~d}, J_{C F}=9.7\right.$ $\mathrm{Hz}), 130.99,124.54,117.09\left(\mathrm{~d}, J_{C F}=18.4 \mathrm{~Hz}\right), 115.92\left(\mathrm{~d}, J_{C F}=3.2 \mathrm{~Hz}\right), 115.31,108.41\left(\mathrm{~d}, J_{C F}\right.$ $=26.2 \mathrm{~Hz}$ ), 83.87, 82.75, 80.82, 79.90, 58.58, 51.83, 49.88, 46.15, 34.05, 31.27, 28.61, 28.25, 28.20, 28.18, 28.00; IR (thin film, $K B r) ~ v_{\max } 3286,3074,2978,2932,1759,1685,1608,1509$, 1455, 1393, 1368, 1246, 1142, 1064, 973, $875 \mathrm{~cm}^{-1}$; HRMS (ESI) $\mathrm{m} / \mathrm{z} 923.4092$ [calcd for

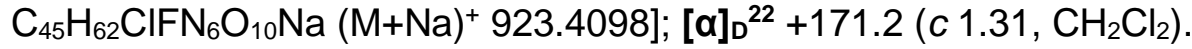

\section{Synthesis of 3,5-Substituted Compounds Submitted for Biological Evaluation}

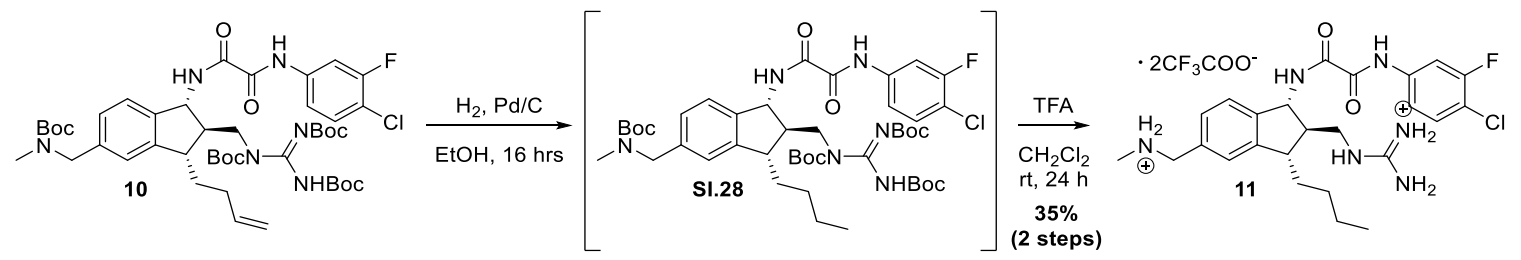

Compound $11 \mathrm{Pd} / \mathrm{C}(10 \%, 5 \mathrm{mg})$ was added in one portion to a stirred solution of 10 (20 mg, 1.0 equiv.) in $\mathrm{EtOH}(300 \mu \mathrm{L}, 0.1 \mathrm{M})$ at rt under argon. The flask was flushed three times with a balloon of hydrogen and the resultant black suspension was stirred under a balloon of hydrogen for $12 \mathrm{~h}$. The suspension was filtered through a short plug of Celite ${ }^{\circledR}$ and the plug was washed with $\mathrm{CH}_{2} \mathrm{Cl}_{2}(10 \mathrm{~mL})$. The filtrate was concentrated in vacuo. The crude residue was taken up in $\mathrm{CH}_{2} \mathrm{Cl}_{2}(222 \mu \mathrm{L}, 0.1 \mathrm{M})$ and cooled to $0{ }^{\circ} \mathrm{C}$ in an ice-water bath. TFA (86 $\mu \mathrm{L}, 50$ equiv.) was added and the mixture was allowed to warm to rt. The reaction was allowed to stir for 18 hours. The solution was then concentrated in vacuo and the resulting crude residue taken up in 1:1 
$\mathrm{CH}_{3} \mathrm{CN}: \mathrm{H}_{2} \mathrm{O}$. The clear solution was purified by HPLC (2 injections of $1000 \mu \mathrm{L}$ each). Eluant: 25:75 to 75:25 acetonitrile/water (12-minute gradient). Flow rate: $15 \mathrm{~mL} / \mathrm{min}$. Product retention time: 7.8 - $8.2 \mathrm{~min}$. Product fractions were combined, and acetonitrile was removed in vacuo. The resulting aqueous solution was deep-frozen ( $-78 \stackrel{\circ}{\circ} \mathrm{C}$ bath) and lyophilized $(0.148 \mathrm{mbar})$ to give the bis-trifluoroacetate salt 11 as a white powder (5.6 mg, 35\%).

${ }^{1} \mathrm{H}$ NMR $\left(500 \mathrm{MHz}, \mathrm{CD}_{3} \mathrm{OD}\right) \delta 7.87(\mathrm{~d}, J=11.6 \mathrm{~Hz}, 1 \mathrm{H}), 7.53-7.43(\mathrm{~m}, 2 \mathrm{H}), 7.40-7.33(\mathrm{~m}$, $2 \mathrm{H}), 5.25(\mathrm{~d}, J=7.3 \mathrm{~Hz}, 1 \mathrm{H}), 4.21(\mathrm{~s}, 2 \mathrm{H}), 3.60-3.46(\mathrm{~m}, 2 \mathrm{H}), 3.05-3.02(\mathrm{~m}, 1 \mathrm{H}), 2.72(\mathrm{~s}$, $3 \mathrm{H}), 2.56-2.44(\mathrm{~m}, 1 \mathrm{H}), 1.96-1.81(\mathrm{~m}, 2 \mathrm{H}), 1.54-1.38(\mathrm{~m}, 4 \mathrm{H}), 0.97(\mathrm{t}, J=6.8 \mathrm{~Hz}, 3 \mathrm{H}) ;{ }^{13} \mathrm{C}$ NMR $\left(150 \mathrm{MHz}, \mathrm{CD}_{3} \mathrm{OD}\right) \delta 162.92\left(\mathrm{q}, J_{C F}=35.5 \mathrm{~Hz}, \mathrm{TFA}\right), 161.90,159.62,159.15\left(\mathrm{~d}, J_{C F}=\right.$ $245.5 \mathrm{~Hz})$ 158.94, 147.82, 143.54, $139.04\left(\mathrm{~d}, J_{C F}=9.9 \mathrm{~Hz}\right), 133.03,131.76,130.07,126.75$, 126.14, $118.06\left(\mathrm{~d}, J_{C F}=3.5 \mathrm{~Hz}\right), 117.26\left(\mathrm{~d}, J_{C F}=17.9 \mathrm{~Hz}\right), 109.75\left(\mathrm{~d}, J_{C F}=26.3 \mathrm{~Hz}\right), 58.35$, 53.49, 53.32, 47.02, 44.29, 34.63, 33.06, 30.12, 24.17, 14.37; HRMS (ESI) m/z 503.2330 [calcd for $\left.\mathrm{C}_{25} \mathrm{H}_{33} \mathrm{ClFN}_{6} \mathrm{O}_{2}(\mathrm{M}+\mathrm{H})+503.2338\right]$.

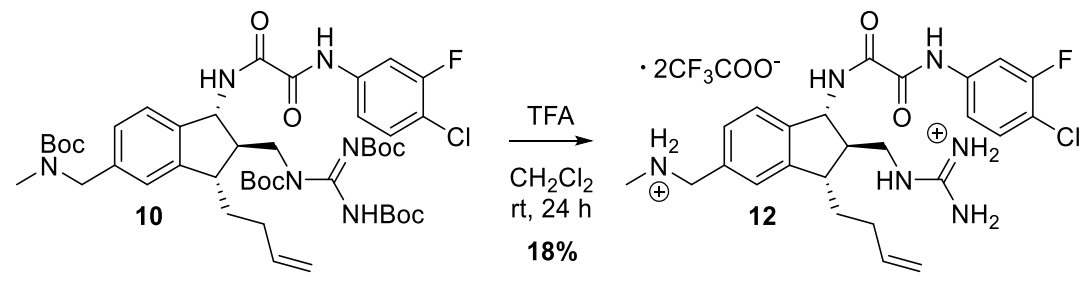

Compound 12 Compound 10 (20 mg, 1.0 equiv.) was taken up in $\mathrm{CH}_{2} \mathrm{Cl}_{2}(222 \mu \mathrm{L}, 0.1 \mathrm{M}$ ) and cooled to $0{ }^{\circ} \mathrm{C}$ in an ice-water bath. TFA $(85.5 \mu \mathrm{L}, 50$ equiv.) was added and the mixture was allowed to warm to rt. Reaction was allowed to stir for 18 hours. The solution was then concentrated in vacuo and the resulting crude residue taken up in $1: 1 \mathrm{CH}_{3} \mathrm{CN}: \mathrm{H}_{2} \mathrm{O}$. The clear solution was purified by HPLC (2 injections of $1000 \mu \mathrm{L}$ each). Eluant: 25:75 to 75:25 acetonitrile/water (12-minute gradient). Flow rate: $15 \mathrm{~mL} / \mathrm{min}$. Product retention time: 7.8-8.1 min. Product fractions were combined, and acetonitrile was removed in vacuo. The resulting aqueous solution was deep-frozen ( $-78 \stackrel{\circ}{\circ} \mathrm{C}$ bath) and lyophilized $(0.148 \mathrm{mbar})$ to give the bistrifluoroacetate salt 12 as a white powder (2.9 mg, 18\%).

${ }^{1} \mathrm{H}$ NMR (400 MHz, $\left.\mathrm{CD}_{3} \mathrm{OD}\right) \delta 7.87$ (dd, $\left.J=11.4,2.3 \mathrm{~Hz}, 1 \mathrm{H}\right), 7.51(\mathrm{dd}, J=9.1,2.1 \mathrm{~Hz}, 1 \mathrm{H})$, $7.49-7.42(\mathrm{~m}, 2 \mathrm{H}), 7.40-7.33(\mathrm{~m}, 2 \mathrm{H}), 5.91$ (dddd, $J=16.9,10.2,6.5,6.5 \mathrm{~Hz}, 1 \mathrm{H}), 5.24(\mathrm{~d}, J$ $=7.0 \mathrm{~Hz}, 1 \mathrm{H}), 5.13-5.07(\mathrm{~m}, 1 \mathrm{H}), 5.03-4.99(\mathrm{~m}, 1 \mathrm{H}), 4.21(\mathrm{~s}, 2 \mathrm{H}), 3.57-3.46(\mathrm{~m}, 2 \mathrm{H}), 3.07$ $(\mathrm{q}, J=6.3 \mathrm{~Hz}, 1 \mathrm{H}), 2.72(\mathrm{~s}, 3 \mathrm{H}), 2.52(\mathrm{p}, J=7.1 \mathrm{~Hz}, 1 \mathrm{H}), 2.33-2.16(\mathrm{~m}, 2 \mathrm{H}), 2.10-1.85(\mathrm{~m}$, 2H). ${ }^{13} \mathrm{C}$ NMR (100 MHz, CD $\left.{ }_{3} \mathrm{OD}\right) \delta 162.92$ (q, $\left.J_{C F}=35.5 \mathrm{~Hz}, \mathrm{TFA}\right), 161.87,159.61,159.15$ (d, $\left.J_{C F}=245.5 \mathrm{~Hz}\right), 158.95,147.60,143.50,139.41,139.04\left(\mathrm{~d}, J_{C F}=9.9 \mathrm{~Hz}\right), 133.11,131.74$, 130.19, 126.79, 126.22, $118.06\left(\mathrm{~d}, J_{C F}=3.5 \mathrm{~Hz}\right), 117.26\left(\mathrm{~d}, J_{C F}=17.9 \mathrm{~Hz}\right), 115.56,109.75(\mathrm{~d}$, $\left.J_{C F}=26.3 \mathrm{~Hz}\right), 58.38,53.45,53.21,46.58,44.30,34.33,33.04,32.01$. HRMS (ESI) $\mathrm{m} / \mathrm{z}$ 501.2185 [calcd for $\mathrm{C}_{25} \mathrm{H}_{31} \mathrm{ClFN}_{6} \mathrm{O}_{2}(\mathrm{M}+\mathrm{H})^{+} 501.2181$ ].

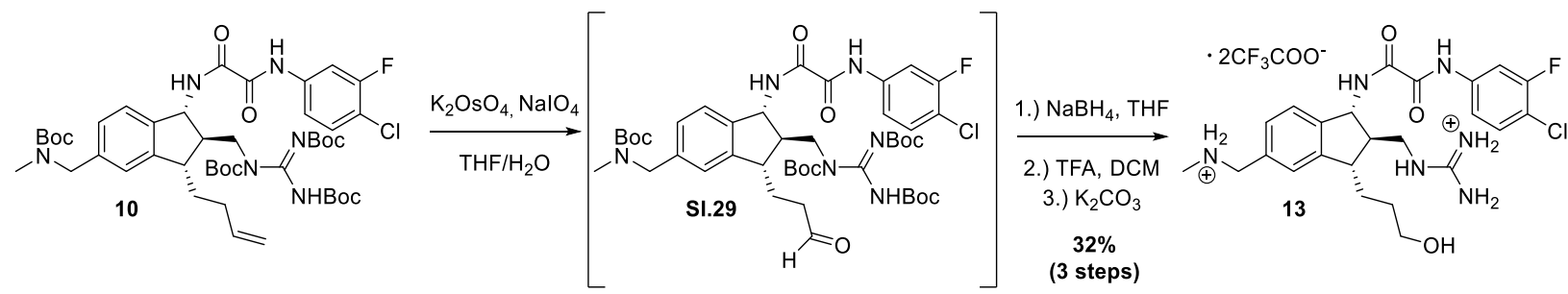

Compound 13 Open to air at $\mathrm{rt}, \mathrm{K}_{2} \mathrm{OsO}_{4} \cdot 2 \mathrm{H}_{2} \mathrm{O}(0.25 \mathrm{mg}, 2 \mathrm{~mol} \%)$ was added in one portion to a stirred solution of 10 (31mg, 1.0 equiv.) in a $4: 1 \mathrm{THF}: \mathrm{H}_{2} \mathrm{O}$ mixture (172 $\left.\mu \mathrm{L}, 0.2 \mathrm{M}\right)$. To this 
mixture was added $\mathrm{NalO}_{4}$ (22 mg, 3.0 equiv.) in one portion. Reaction was stirred for 4 hours, at which time TLC (30\% EA/hexanes) indicated consumption of starting material. Aqueous saturated $\mathrm{NaHCO}_{3}(0.5 \mathrm{~mL})$ was added and the aqueous layer was extracted with $\mathrm{Et} 2 \mathrm{O}(3 \times 0.5$ $\mathrm{mL}$ ). The organic layers were combined, dried over $\mathrm{Na}_{2} \mathrm{SO}_{4}$, and concentrated in vacuo. The crude residue was then taken up in $\mathrm{EtOH}(350 \mu \mathrm{L}, 0.1 \mathrm{M})$ and cooled to $0{ }^{\circ} \mathrm{C}$ in an ice-water bath. To this solution, $\mathrm{NaBH}_{4}(3 \mathrm{mg}, 2$ equiv.) was added in one portion. The reaction was allowed to stir for 30 mins, at which time $\mathrm{H}_{2} \mathrm{O}(300 \mu \mathrm{L})$ was added. The aqueous layer was extracted with EtOAc $(3 \times 0.5 \mathrm{~mL})$ and the organic layers were combined, dried over $\mathrm{Na}_{2} \mathrm{SO}_{4}$, and concentrated in vacuo. The crude residue was taken up in $\mathrm{CH}_{2} \mathrm{Cl}_{2}(1 \mathrm{~mL}, 0.04 \mathrm{M})$ and cooled to $0{ }^{\circ} \mathrm{C}$ in an ice-water bath. TFA (146.3 $\mu \mathrm{L}, 50$ equiv.) was added and the mixture was allowed to warm to rt. The reaction was allowed to stir for 18 hours. To this solution was added solid $\mathrm{K}_{2} \mathrm{CO}_{3}(150 \mathrm{mg})$ and the solution was allowed to stir for 3 additional hours. The solid residue was then filtered and washed with $\mathrm{MeOH}(1 \mathrm{~mL})$. The filtered solution was then concentrated in vacuo and the resulting crude residue taken up in $1: 1 \mathrm{CH}_{3} \mathrm{CN}: \mathrm{H}_{2} \mathrm{O}$. The clear solution was purified by HPLC (2 injections of $1000 \mu \mathrm{L}$ each). Eluant: 25:75 to 75:25 acetonitrile/water (12-minute gradient). Flow rate: $15 \mathrm{~mL} / \mathrm{min}$. Product retention time: 5.8-6.3 min. Product fractions were combined, and acetonitrile was removed in vacuo. The resulting aqueous solution was deep-frozen ( $-78^{\circ} \mathrm{C}$ bath) and lyophilized $(0.148 \mathrm{mbar})$ to give the bistrifluoroacetate salt 13 as a white powder $(8 \mathrm{mg}, 32 \%)$.

${ }^{1} \mathrm{H}$ NMR $\left(500 \mathrm{MHz}, \mathrm{CD}_{3} \mathrm{OD}\right) \delta 7.88$ (dd, $\left.J=11.3,2.3 \mathrm{~Hz}, 1 \mathrm{H}\right), 7.52$ (dd, $\left.J=8.8,1.8 \mathrm{~Hz}, 1 \mathrm{H}\right)$, $7.48-7.45(\mathrm{~m}, 2 \mathrm{H}), 7.39-7.34(\mathrm{~m}, 2 \mathrm{H}), 5.27(\mathrm{~d}, J=7.5 \mathrm{~Hz}, 1 \mathrm{H}), 4.21(\mathrm{~s}, 2 \mathrm{H}), 3.65(\mathrm{t}, J=6.2$ $\mathrm{Hz}, 2 \mathrm{H}), 3.58(\mathrm{dd}, J=14.0,5.3 \mathrm{~Hz}, 1 \mathrm{H}), 3.51(\mathrm{dd}, J=14.0,7.2 \mathrm{~Hz}, 1 \mathrm{H}), 3.08(\mathrm{q}, J=6.1 \mathrm{~Hz}$, $1 \mathrm{H}), 2.72(\mathrm{~s}, 3 \mathrm{H}), 2.55-2.50(\mathrm{~m}, 1 \mathrm{H}), 2.01-1.91(\mathrm{~m}, 2 \mathrm{H}), 1.76-1.68(\mathrm{~m}, 1 \mathrm{H}), 1.66-1.56(\mathrm{~m}$, $1 \mathrm{H}) ;{ }^{13} \mathrm{C}$ NMR (150 MHz, CD $\left.3 \mathrm{OD}\right) \delta 162.89$ (q, J JF $\left.=35.5 \mathrm{~Hz}, \mathrm{TFA}\right), 161.91,159.61,159.15$ (d, $\left.J_{C F}=245.8 \mathrm{~Hz}\right), 158.93,147.42,143.67,139.04\left(\mathrm{~d}, J_{C F}=9.9 \mathrm{~Hz}\right), 133.01,131.77,130.14$, 126.73, 126.11, $118.06\left(\mathrm{~d}, J_{C F}=3.5 \mathrm{~Hz}\right), 117.31\left(\mathrm{~d}, J_{C F}=19 \mathrm{~Hz}\right), 109.75\left(\mathrm{~d}, J_{C F}=26.3 \mathrm{~Hz}\right)$, 62.85, 58.33, 53.48, 53.06, 49.57, 46.69, 44.16, 33.05, 30.55, 30.20; HRMS (ESI) $\mathrm{m} / \mathrm{z} 505.2118$ [calcd for $\mathrm{C}_{24} \mathrm{H}_{31} \mathrm{ClFN}_{6} \mathrm{O}_{3}(\mathrm{M}+\mathrm{H})^{+} 505.2130$ ].

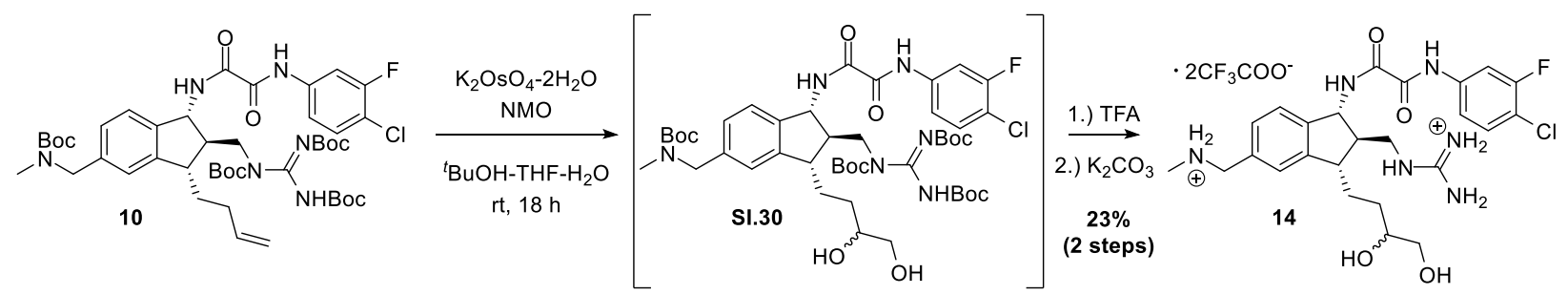

Compound 14 Open to air at rt, $\mathrm{K}_{2} \mathrm{OsO}_{4} \cdot 2 \mathrm{H}_{2} \mathrm{O}(5.5 \mathrm{mg}, 7 \mathrm{~mol} \%)$ was added in one portion to a stirred solution of 18 (192.1 mg, 1.0 equiv.) in a 5:5:1 THF: ${ }^{\mathrm{BuOH}}: \mathrm{H}_{2} \mathrm{O}$ mixture $(7.1 \mathrm{~mL}, 0.03 \mathrm{M})$. To this mixture was added 4-methylmorpholine $\mathrm{N}$-oxide $(32.5 \mathrm{mg}, 1.3$ equiv.) in one portion. Reaction was stirred for 20 hours, at which time TLC (30\% EA/hexanes) indicated consumption of starting material. Aqueous saturated $\mathrm{Na}_{2} \mathrm{~S}_{2} \mathrm{O}_{3}(10 \mathrm{~mL})$ was added and the aqueous layer was extracted with $\mathrm{Et}_{2} \mathrm{O}(3 \times 5 \mathrm{~mL})$. The organic layers were combined, dried over $\mathrm{Na}_{2} \mathrm{SO}_{4}$, and concentrated in vacuo. The crude residue was taken up in $\mathrm{CH}_{2} \mathrm{Cl}_{2}(1.2 \mathrm{~mL}, 0.1 \mathrm{M})$ and cooled to $0{ }^{\circ} \mathrm{C}$ in an ice-water bath. TFA ( $272.5 \mu \mathrm{L}, 50$ equiv.) was added and the mixture was allowed to warm to rt. The reaction was allowed to stir for 18 hours. To this solution was added solid $\mathrm{K}_{2} \mathrm{CO}_{3}(300 \mathrm{mg})$ and the solution was allowed to stir for 3 additional hours. The solid residue was then filtered and washed with $\mathrm{MeOH}(3 \mathrm{~mL})$. The filtered solution was then concentrated in vacuo and the resulting crude residue taken up in $1: 1 \mathrm{CH}_{3} \mathrm{CN}: \mathrm{H}_{2} \mathrm{O}$. The clear solution was 
purified by HPLC (3 injections of $1000 \mu \mathrm{L}$ each). Eluant: 25:75 to 75:25 acetonitrile/water (12minute gradient). Flow rate: $15 \mathrm{~mL} / \mathrm{min}$. Product retention time: $7.5-8.0 \mathrm{~min}$. Product fractions were combined, and acetonitrile was removed in vacuo. The resulting aqueous solution was deep-frozen ( $-78{ }^{\circ} \mathrm{C}$ bath) and lyophilized (0.148 mbar) to give the bis-trifluoroacetate salt 14 as a white powder (38.2 $\mathrm{mg}, 23 \%)$.

${ }^{1} \mathrm{H}$ NMR $\left(400 \mathrm{MHz}, \mathrm{CD}_{3} \mathrm{OD}\right) \delta 7.87$ (dd, $\left.J=11.4,2.3 \mathrm{~Hz}, 1 \mathrm{H}\right), 7.51$ (dd, $J=9.1,2.1 \mathrm{~Hz}, 1 \mathrm{H}$ ), $7.48-7.42(\mathrm{~m}, 2 \mathrm{H}), 7.39-7.32(\mathrm{~m}, 2 \mathrm{H}), 5.26(\mathrm{~d}, J=7.4 \mathrm{~Hz}, 1 \mathrm{H}), 4.21(\mathrm{~s}, 2 \mathrm{H}), 3.68-3.62(\mathrm{~m}$, $1 \mathrm{H}), 3.61-3.47(\mathrm{~m}, 4 \mathrm{H}), 3.09(\mathrm{q}, J=5.8 \mathrm{~Hz}, 1 \mathrm{H}), 2.71(\mathrm{~s}, 3 \mathrm{H}), 2.58-2.46(\mathrm{~m}, 1 \mathrm{H}), 2.16-2.06$ $(\mathrm{m}, 1 \mathrm{H}), 1.98-1.85(\mathrm{~m}, 1 \mathrm{H}), 1.75-1.58(\mathrm{~m}, 1 \mathrm{H}), 1.57-1.47(\mathrm{~m}, 0.5 \mathrm{H}), 1.44-1.35(\mathrm{~m}, 0.5 \mathrm{H})$; ${ }^{13} \mathrm{C}$ NMR (150 MHz, CD $\left.{ }_{3} \mathrm{OD}\right) \delta 162.83$ (q, $\left.J_{C F}=35 \mathrm{~Hz}, \mathrm{TFA}\right), 161.90,161.89,159.61,159.15$ (d, $\left.J_{C F}=245.5 \mathrm{~Hz}\right) 158.93,158.92,147.35,147.30,143.68,143.66,139.04\left(\mathrm{~d}, J_{C F}=9.9 \mathrm{~Hz}\right)$, $132.99,131.75,130.15,130.13,126.77,126.74,126.06,118.06\left(\mathrm{~d}, J_{C F}=3.5 \mathrm{~Hz}\right), 117.26\left(\mathrm{~d}, J_{C F}\right.$ $=18 \mathrm{~Hz}$ ), $109.75\left(\mathrm{~d}, J_{C F}=27 \mathrm{~Hz}\right), 73.27,73.16,67.21,67.19,58.34,53.48,53.47,52.90,52.87$, 49.57, 46.81, 44.16, 33.05, 33.03, 30.81, 30.77, 30.00, 29.85; IR (thin film, KBr) $v_{\max } 3286$, 2978, 2932, 1671, 1558, 1540, 1508, 1456, 1428, 1201, $1133 \mathrm{~cm}^{-1}$; HRMS (ESI) m/z 535.2234 [calcd for $\left.\mathrm{C}_{25} \mathrm{H}_{33} \mathrm{ClFN}_{6} \mathrm{O}_{4}(\mathrm{M}+\mathrm{H})^{+} 535.2236\right] ;[\alpha]_{D}{ }^{24}+21.2\left(c 0.12, \mathrm{CH}_{3} \mathrm{OH}\right)$.

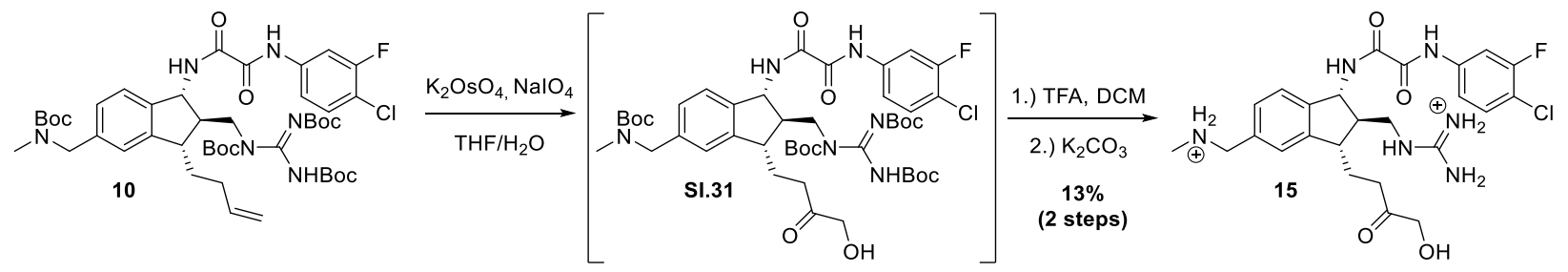

Compound 15 Open to air at $\mathrm{rt}, \mathrm{K}_{2} \mathrm{OsO}_{4} \cdot 2 \mathrm{H}_{2} \mathrm{O}(0.22 \mathrm{mg}, 7 \mathrm{~mol} \%)$ was added in one portion to a stirred solution of 10 (27mg, 1.0 equiv.) in a 4:1 THF: $\mathrm{H}_{2} \mathrm{O}$ mixture $(500 \mu \mathrm{L}, 0.06 \mathrm{M})$. To this mixture was added $\mathrm{NaIO}_{4}(20 \mathrm{mg}, 3.0$ equiv.) in one portion. Reaction was stirred for 4 hours, at which time TLC (30\% EA/hexanes) indicated consumption of starting material. Aqueous saturated $\mathrm{NaHCO}_{3}(1 \mathrm{~mL})$ was added and the aqueous layer was extracted with $\mathrm{Et}_{2} \mathrm{O}(3 \times 1$ $\mathrm{mL}$ ). The organic layers were combined, dried over $\mathrm{Na}_{2} \mathrm{SO}_{4}$, and concentrated in vacuo. The crude residue was taken up in $\mathrm{CH}_{2} \mathrm{Cl}_{2}(1 \mathrm{~mL}, 0.03 \mathrm{M})$ and cooled to $0{ }^{\circ} \mathrm{C}$ in an ice-water bath. TFA (146.3 $\mu \mathrm{L}, 50$ equiv.) was added and the mixture was allowed to warm to rt. The reaction was allowed to stir for 18 hours. To this solution was added solid $\mathrm{K}_{2} \mathrm{CO}_{3}(150 \mathrm{mg}$ ) and the solution was allowed to stir for 3 additional hours. The solid residue was then filtered and washed with $\mathrm{MeOH}(1 \mathrm{~mL})$. The filtered solution was then concentrated in vacuo and the resulting crude residue taken up in $1: 1 \mathrm{CH}_{3} \mathrm{CN}: \mathrm{H}_{2} \mathrm{O}$. The clear solution was purified by HPLC (2 injections of $1000 \mu \mathrm{L}$ each). Eluant: $25: 75$ to $75: 25$ acetonitrile/water (12-minute gradient). Flow rate: $15 \mathrm{~mL} / \mathrm{min}$. Product retention time: 6.3-6.8 min. Product fractions were combined, and acetonitrile was removed in vacuo. The resulting aqueous solution was deep-frozen $(-78 \stackrel{\circ}{\circ}$ bath) and lyophilized (0.148 mbar) to give the bis-trifluoroacetate salt $\mathbf{1 5}$ as a white powder (3 $\mathrm{mg}, 13 \%)$.

${ }^{1} \mathrm{H}$ NMR $\left(500 \mathrm{MHz}, \mathrm{CD}_{3} \mathrm{OD}\right) \delta 7.87$ (dd, $\left.J=11.3,2.2 \mathrm{~Hz}, 1 \mathrm{H}\right), 7.51$ (dd, $J=9.1,2.0 \mathrm{~Hz}, 1 \mathrm{H}$ ), $7.48-7.41(\mathrm{~m}, 2 \mathrm{H}), 7.40-7.32(\mathrm{~m}, 2 \mathrm{H}), 5.25(\mathrm{~d}, J=7.6 \mathrm{~Hz}, 1 \mathrm{H}), 4.24-4.15(\mathrm{~m}, 4 \mathrm{H}), 3.59$ (dd, $J=14.1,5.3 \mathrm{~Hz}, 1 \mathrm{H}$ ), 3.51 (dd, $J=14.0,7.5 \mathrm{~Hz}, 1 \mathrm{H}$ ), 3.10 (q, $J=5.5 \mathrm{~Hz}, 1 \mathrm{H}$ ), $2.72(\mathrm{~s}, 3 \mathrm{H}$ ), $2.61(\mathrm{t}, J=7.3 \mathrm{~Hz}, 2 \mathrm{H}), 2.50-2.44(\mathrm{~m}, 1 \mathrm{H}), 2.22-2.18(\mathrm{~m}, 2 \mathrm{H}) ;{ }^{13} \mathrm{C}$ NMR $\left(150 \mathrm{MHz}, \mathrm{CD}_{3} \mathrm{OD}\right)$ $\delta 212.60,162.83$ (q, $\left.J_{C F}=35 \mathrm{~Hz}, \mathrm{TFA}\right), 161.87,159.59,159.15\left(\mathrm{~d}, J_{C F}=245.5 \mathrm{~Hz}\right), 158.90$, 146.60, 143.90, $139.02\left(\mathrm{~d}, J_{C F}=9.9 \mathrm{~Hz}\right), 133.11,131.77,130.33,126.69,126.15,118.05\left(\mathrm{~d}, J_{C F}\right.$ $=3.5 \mathrm{~Hz}), 117.31\left(\mathrm{~d}, J_{C F}=17 \mathrm{~Hz}\right), 109.75\left(\mathrm{~d}, J_{C F}=28 \mathrm{~Hz}\right), 68.73,58.31,53.45,52.58,49.57$, 
46.29, 44.10, 35.54, 33.09, 26.73; HRMS (ESI) $\mathrm{m} / 2533.2073$ [calcd for $\mathrm{C}_{25} \mathrm{H}_{31} \mathrm{ClFN}_{6} \mathrm{O}_{4}(\mathrm{M}+\mathrm{H})^{+}$ 533.2079].

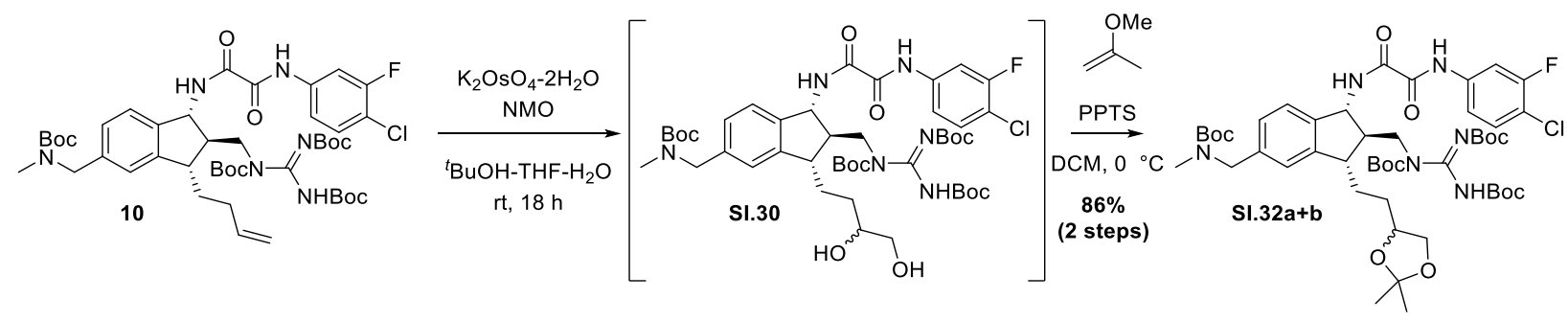

Compound SI.32a+b Open to air at rt, $\mathrm{K}_{2} \mathrm{OsO}_{4} \cdot 2 \mathrm{H}_{2} \mathrm{O}(3 \mathrm{mg}, 7 \mathrm{~mol} \%)$ was added in one portion to a stirred solution of $\mathbf{1 0}$ (100 mg, 1.0 equiv.) in a 5:5:1 THF: $\mathrm{BuOH}: \mathrm{H}_{2} \mathrm{O}$ mixture (1.1 mL, 0.1 M). To this mixture was added 4-methylmorpholine $\mathrm{N}$-oxide (17 mg, 1.3 equiv.) in one portion. Reaction was stirred for 20 hours, at which time TLC (30\% EA/hexanes) indicated consumption of starting material. Aqueous saturated $\mathrm{Na}_{2} \mathrm{~S}_{2} \mathrm{O}_{3}(2 \mathrm{~mL})$ was added and the aqueous layer was extracted with $\mathrm{Et}_{2} \mathrm{O}(3 \times 2 \mathrm{~mL})$. The organic layers were combined, dried over $\mathrm{Na}_{2} \mathrm{SO}_{4}$, and concentrated in vacuo. The crude SI.30 and PPTS (2.8 mg, 0.1 equiv.) were dissolved in anhydrous $\mathrm{CH}_{2} \mathrm{Cl}_{2}(1 \mathrm{~mL})$ and cooled to $0{ }^{\circ} \mathrm{C}$ in an ice-water bath. To this mixture was added 2methoxypropene (22 $\mu \mathrm{L}, 2.0$ equiv.) in one portion. Reaction was warned to rt and stirred for 1 hour, at which time TLC (50\% EA/hexanes) indicated consumption of starting material. Aqueous saturated $\mathrm{NaHCO}_{3}(1 \mathrm{~mL})$ was added and the aqueous layer was extracted with $\mathrm{CH}_{2} \mathrm{Cl}_{2}(3 \times 1$ $\mathrm{mL}$ ). The organic layers were combined, dried over $\mathrm{Na}_{2} \mathrm{SO}_{4}$, and concentrated in vacuo. The crude residue was purified by flash column chromatography $(25 \%-30 \% \mathrm{EtOAc/hexanes)}$ to give SI.32a+b (93 mg, 86\%) as an oil.

${ }^{1} \mathrm{H}$ NMR $\left(500 \mathrm{MHz}, \mathrm{CDCl}_{3}\right) \delta 9.28(\mathrm{~s}, 1 \mathrm{H}), 7.80(\mathrm{~s}, 1 \mathrm{H}), 7.71(\mathrm{~d}, J=10.6 \mathrm{~Hz}, 1 \mathrm{H}), 7.37(\mathrm{t}, J=8.3$ $\mathrm{Hz}, 1 \mathrm{H}), 7.19(\mathrm{dd}, J=19.7,8.2 \mathrm{~Hz}, 2 \mathrm{H}), 7.09(\mathrm{~s}, 2 \mathrm{H}), 5.23(\mathrm{dd}, J=7.0,7.0 \mathrm{~Hz}, 1 \mathrm{H}), 4.41(\mathrm{~s}$, 2H), $4.10-4.02(\mathrm{~m}, 4 \mathrm{H}), 3.53-3.48(\mathrm{~m}, 2 \mathrm{H}), 2.94(\mathrm{q}, \mathrm{J}=5.8 \mathrm{~Hz}, 1 \mathrm{H}), 2.80(\mathrm{~s}, 3 \mathrm{H}), 2.63-2.56$ $(\mathrm{m}, 1 \mathrm{H}), 2.02-1.89(\mathrm{~m}, 1 \mathrm{H}), 1.84-1.56(\mathrm{~m}, 3 \mathrm{H}), 1.47(\mathrm{~s}, 36 \mathrm{H}), 1.40(\mathrm{~s}, 1.5 \mathrm{H}), 1.39(\mathrm{~s}, 1.5 \mathrm{H})$, $1.34(\mathrm{~s}, 3 \mathrm{H})$. LRMS (ESI) $\mathrm{m} / \mathrm{z} 975.9$ [calcd for $\mathrm{C}_{48} \mathrm{H}_{69} \mathrm{CIFN}_{6} \mathrm{O}_{12}(\mathrm{M}+\mathrm{H})^{+} 975.5$ ].

The resulting diastereomeric mixture was taken up in $3 \mathrm{~mL} 5 \%$ isopropanol in hexanes. The clear solution was purified by normal phase chiral HPLC (3 injections of $1000 \mu \mathrm{L}$ each). Eluant: 10:90 to $70: 30$ isopropanol/hexanes (15-minute gradient). Flow rate: $15 \mathrm{~mL} / \mathrm{min}$. Product retention times: Peak 1 11.5-12.3 min. Peak 2 12.8-14.5 min. Peak 1 and Peak 2 product fractions were combined separately, and isopropanol/hexanes was removed in vacuo. See below for chromatogram of the separation. 


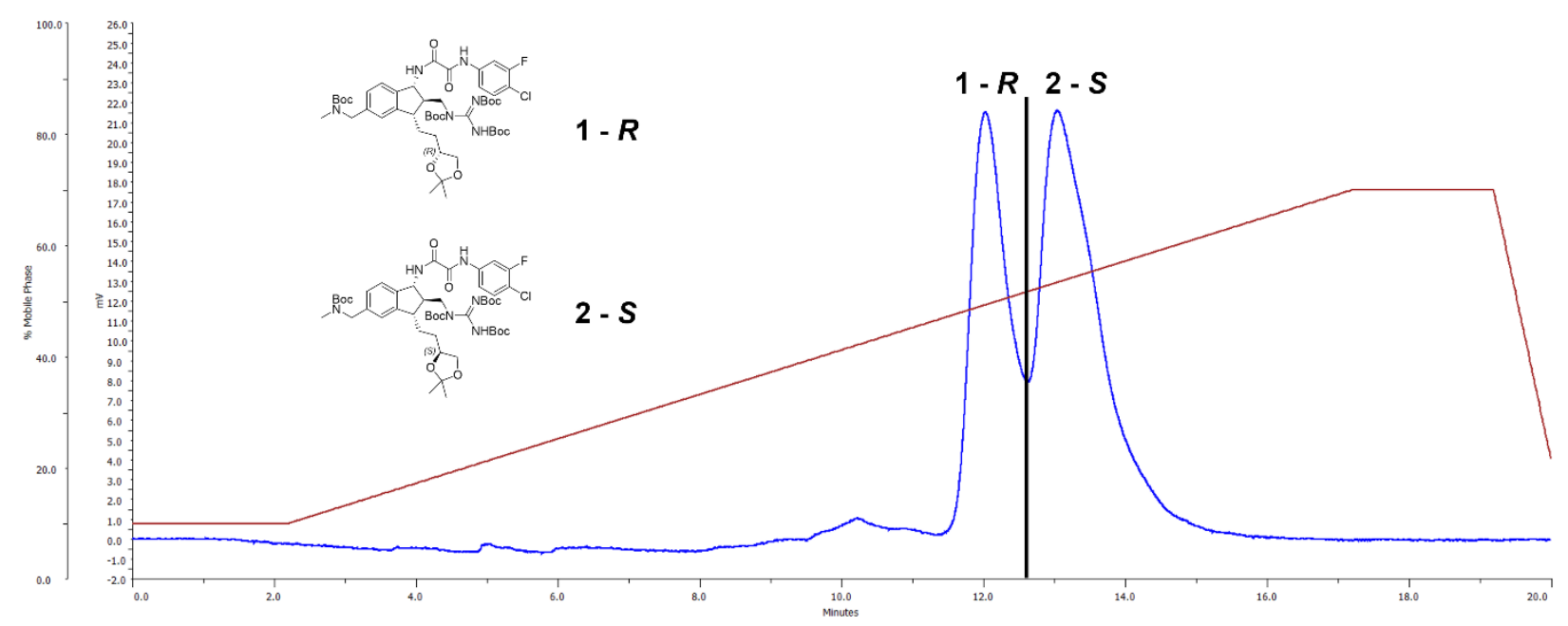

Method: column: Chiralpak ${ }^{\circledR} \mathrm{AD}-\mathrm{H}(21 \times 250 \mathrm{~mm}, 5 \mu \mathrm{m})$; eluent: $10 \%$ isopropanol in hexanes to $70 \%$ isopropanol in hexanes; gradient time: 15 mins; flow rate: $15 \mathrm{~mL} / \mathrm{min}$; pressure: 900 psi. Retention times: $(R)$ Diastereomer $(\mathbf{S I . 3 4})=11.9 \mathrm{~min},(S)$ Diastereomer $(\mathbf{S I . 3 3})=13.2 \mathrm{~min}$.

Peak 1 (SI.34): ${ }^{1} \mathrm{H}$ NMR $\left(500 \mathrm{MHz}, \mathrm{CDCl}_{3}\right) \delta 9.29$ (s, 1H), 7.81 (s, 1H), 7.71 (dd, $J=10.6,2.3$ $\mathrm{Hz}, 1 \mathrm{H}$ ), 7.37 (t, $J=8.3 \mathrm{~Hz}, 1 \mathrm{H}$ ), 7.19 (dd, $J=19.0,7.4 \mathrm{~Hz}, 2 \mathrm{H}), 7.08$ (s, 2H), 5.23 (dd, $J=7.0$, $7.0 \mathrm{~Hz}, 1 \mathrm{H}), 4.41(\mathrm{~s}, 2 \mathrm{H}), 4.11-4.02(\mathrm{~m}, 4 \mathrm{H}), 3.52$ (dd, $J=7.5 \mathrm{~Hz}, 1 \mathrm{H}), 2.94$ (q, J = $5.8 \mathrm{~Hz}$, $1 \mathrm{H}), 2.80(\mathrm{~s}, 3 \mathrm{H}), 2.63-2.56(\mathrm{~m}, 1 \mathrm{H}), 1.96-1.88(\mathrm{~m}, 1 \mathrm{H}), 1.84-1.58(\mathrm{~m}, 3 \mathrm{H}), 1.47(\mathrm{~s}, 36 \mathrm{H})$, $1.39(\mathrm{~s}, 3 \mathrm{H}), 1.34(\mathrm{~s}, 3 \mathrm{H})$.

Peak 2 (SI.33): ${ }^{1} \mathrm{H}$ NMR $\left(500 \mathrm{MHz}, \mathrm{CDCl}_{3}\right) \delta 9.28$ (s, 1H), 7.80 (s, 1H), 7.71 (dd, $J=10.6,2.3$ $\mathrm{Hz}, 1 \mathrm{H}), 7.37$ (t, $J=8.3 \mathrm{~Hz}, 1 \mathrm{H}), 7.19(\mathrm{dd}, J=19.7,8.2 \mathrm{~Hz}, 2 \mathrm{H}), 7.09(\mathrm{~s}, 2 \mathrm{H}), 5.23$ (dd, $J=7.0$, $7.0 \mathrm{~Hz}, 1 \mathrm{H}), 4.41(\mathrm{~s}, 2 \mathrm{H}), 4.10-4.02(\mathrm{~m}, 4 \mathrm{H}), 3.51(\mathrm{dd}, J=7.5 \mathrm{~Hz}, 1 \mathrm{H}), 2.92(\mathrm{q}, J=5.8 \mathrm{~Hz}$, $1 \mathrm{H}), 2.80(\mathrm{~s}, 3 \mathrm{H}), 2.63-2.56(\mathrm{~m}, 1 \mathrm{H}), 2.02-1.89(\mathrm{~m}, 1 \mathrm{H}), 1.84-1.56(\mathrm{~m}, 3 \mathrm{H}), 1.47(\mathrm{~s}, 36 \mathrm{H})$, $1.40(\mathrm{~s}, 3 \mathrm{H}), 1.34(\mathrm{~s}, 3 \mathrm{H})$.

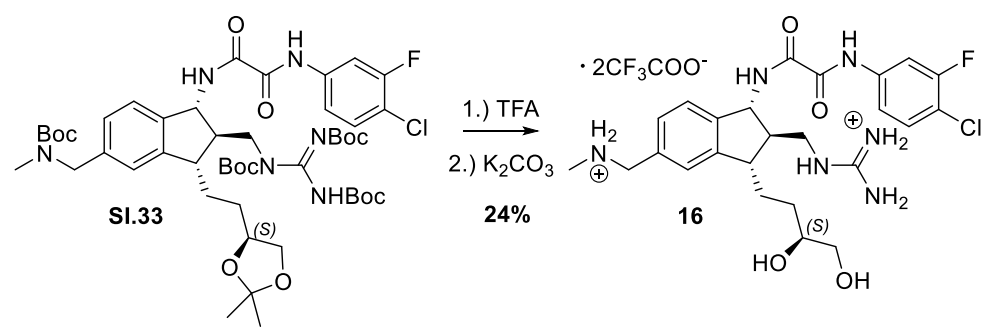

Peak 2 - Compound 16 The crude residue (16 mg, 1.0 equiv.) was taken up in $\mathrm{CH}_{2} \mathrm{Cl}_{2}(200 \mu \mathrm{L}$, $0.1 \mathrm{M})$ and cooled to $0{ }^{\circ} \mathrm{C}$ in an ice-water bath. TFA (38 $\mu \mathrm{L}, 50$ equiv.) was added and the mixture was allowed to warm to rt. The reaction was allowed to stir for 18 hours. To this solution was added solid $\mathrm{K}_{2} \mathrm{CO}_{3}(40 \mathrm{mg})$ and the solution was allowed to stir for 3 additional hours. The solid residue was then filtered and washed with $\mathrm{MeOH}(300 \mu \mathrm{L})$. The filtered solution was then concentrated in vacuo and the resulting crude residue taken up in $1: 1 \mathrm{CH}_{3} \mathrm{CN}: \mathrm{H}_{2} \mathrm{O}$. The clear solution was purified by HPLC (1 injection of $1000 \mu \mathrm{L}$ ). Eluant: 25:75 to 75:25 acetonitrile/water (12-minute gradient). Flow rate: $15 \mathrm{~mL} / \mathrm{min}$. Product retention time: 7.5 - 8.0 
min. Product fractions were combined, and acetonitrile was removed in vacuo. The resulting aqueous solution was deep-frozen $(-78 \stackrel{\circ}{\circ}$ bath) and lyophilized $(0.148 \mathrm{mbar})$ to give the bistrifluoroacetate salt 16 as a white powder ( $3 \mathrm{mg}, 24 \%)$.

${ }^{1} \mathrm{H}$ NMR $\left(500 \mathrm{MHz}, \mathrm{CD}_{3} \mathrm{OD}\right) \delta 7.88(\mathrm{dd}, J=11.3,2.2 \mathrm{~Hz}, 1 \mathrm{H}), 7.51(\mathrm{dd}, J=8.8,1.8 \mathrm{~Hz}, 1 \mathrm{H})$, $7.49-7.42(\mathrm{~m}, 2 \mathrm{H}), 7.40-7.30(\mathrm{~m}, 2 \mathrm{H}), 5.26(\mathrm{~d}, J=7.5 \mathrm{~Hz}, 1 \mathrm{H}), 4.20(\mathrm{~s}, 2 \mathrm{H}), 3.68-3.63(\mathrm{~m}$, $1 \mathrm{H}), 3.58(\mathrm{dd}, J=13.9,5.1 \mathrm{~Hz}, 1 \mathrm{H}), 3.54-3.44(\mathrm{~m}, 3 \mathrm{H}), 3.09(\mathrm{q}, J=5.8 \mathrm{~Hz}, 1 \mathrm{H}), 2.71(\mathrm{~s}, 3 \mathrm{H})$, $2.55-2.50(\mathrm{~m}, 1 \mathrm{H}), 2.14-2.07(\mathrm{~m}, 1 \mathrm{H}), 1.96-1.89(\mathrm{~m}, 1 \mathrm{H}), 1.65-1.60(\mathrm{~m}, 1 \mathrm{H}), 1.56-1.48$ $(\mathrm{m}, 1 \mathrm{H}) ;{ }^{13} \mathrm{C}$ NMR $\left(125 \mathrm{MHz}, \mathrm{CD}_{3} \mathrm{OD}\right) \delta 162.83$ (q, $\left.J_{C F}=35.5 \mathrm{~Hz}, \mathrm{TFA}\right), 161.87,159.60,159.07$ $\left(\mathrm{d}, J_{C F}=245 \mathrm{~Hz}\right), 158.89,147.33,143.66,139.04\left(\mathrm{~d}, J_{C F}=9.9 \mathrm{~Hz}\right), 132.99,131.75,130.14$, 126.75, 126.04, $118.06\left(\mathrm{~d}, J_{C F}=3.5 \mathrm{~Hz}\right), 117.25$ (d, $\left.J_{C F}=19 \mathrm{~Hz}\right), 109.75\left(\mathrm{~d}, J_{C F}=26.3 \mathrm{~Hz}\right)$, 73.26, 67.18, 58.32, 53.45, 52.84, 49.63, 46.78, 44.13, 33.02, 30.78, 29.95; HRMS (ESI) $\mathrm{m} / \mathrm{z}$ 535.2233 [calcd for $\mathrm{C}_{25} \mathrm{H}_{33} \mathrm{CIFN}_{6} \mathrm{O}_{4}(\mathrm{M}+\mathrm{H})^{+} 535.2236$ ].

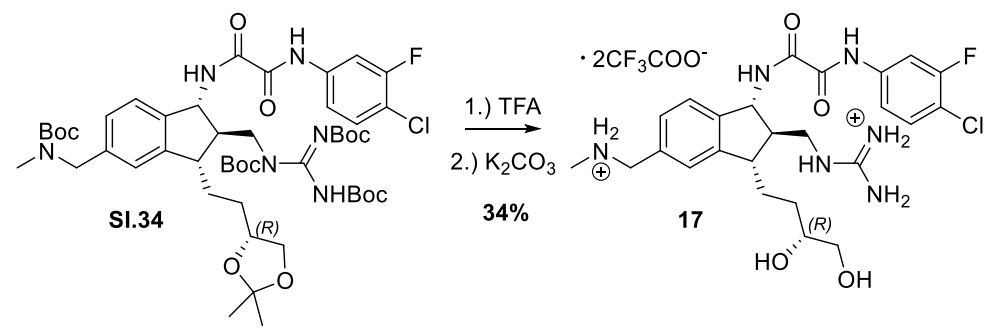

Peak 1 - Compound 17 The crude residue (18 mg, 1.0 equiv.) was taken up in $\mathrm{CH}_{2} \mathrm{Cl}_{2}(200 \mu \mathrm{L}$, $0.1 \mathrm{M})$ and cooled to $0{ }^{\circ} \mathrm{C}$ in an ice-water bath. TFA (44 $\mu \mathrm{L}, 50$ equiv.) was added and the mixture was allowed to warm to rt. The reaction was allowed to stir for 18 hours. To this solution was added solid $\mathrm{K}_{2} \mathrm{CO}_{3}(50 \mathrm{mg})$ and the solution was allowed to stir for 3 additional hours. The solid residue was then filtered and washed with $\mathrm{MeOH}(300 \mu \mathrm{L})$. The filtered solution was then concentrated in vacuo and the resulting crude residue taken up in $1: 1 \mathrm{CH}_{3} \mathrm{CN}: \mathrm{H}_{2} \mathrm{O}$. The clear solution was purified by HPLC (1 injection of $1000 \mu \mathrm{L}$ ). Eluant: 25:75 to 75:25 acetonitrile/water (12-minute gradient). Flow rate: $15 \mathrm{~mL} / \mathrm{min}$. Product retention time: 7.5 - 8.0 min. Product fractions were combined, and acetonitrile was removed in vacuo. The resulting aqueous solution was deep-frozen $\left(-78^{\circ} \mathrm{C}\right.$ bath) and lyophilized $(0.148 \mathrm{mbar})$ to give the bistrifluoroacetate salt 17 as a white powder (5 mg, 34\%).

${ }^{1} \mathrm{H}$ NMR $\left(500 \mathrm{MHz}, \mathrm{CD}_{3} \mathrm{OD}\right) \delta 7.88(\mathrm{dd}, J=11.3,2.1 \mathrm{~Hz}, 1 \mathrm{H}), 7.51(\mathrm{dd}, J=8.8,1.8 \mathrm{~Hz}, 1 \mathrm{H})$, $7.48-7.40(\mathrm{~m}, 2 \mathrm{H}), 7.39-7.32(\mathrm{~m}, 2 \mathrm{H}), 5.26(\mathrm{~d}, J=7.6 \mathrm{~Hz}, 1 \mathrm{H}), 4.21(\mathrm{~s}, 2 \mathrm{H}), 3.68-3.63(\mathrm{~m}$, $1 \mathrm{H}), 3.57(\mathrm{dd}, J=14.0,5.6 \mathrm{~Hz}, 1 \mathrm{H}), 3.52-3.49(\mathrm{~m}, 3 \mathrm{H}), 3.10(\mathrm{q}, J=5.5 \mathrm{~Hz}, 1 \mathrm{H}), 2.72(\mathrm{~s}, 3 \mathrm{H})$, $2.55-2.49(\mathrm{~m}, 1 \mathrm{H}), 2.15-2.07(\mathrm{~m}, 1 \mathrm{H}), 1.96-1.89(\mathrm{~m}, 1 \mathrm{H}), 1.75-1.68(\mathrm{~m}, 1 \mathrm{H}), 1.43-1.35$ $(\mathrm{m}, 1 \mathrm{H}) ;{ }^{13} \mathrm{C}$ NMR $\left(125 \mathrm{MHz}, \mathrm{CD}_{3} \mathrm{OD}\right) \delta 162.82$ (q, $\left.J_{C F}=35.5 \mathrm{~Hz}, \mathrm{TFA}\right), 161.90,159.60,159.15$ $\left(\mathrm{d}, J_{C F}=245.8 \mathrm{~Hz}\right), 158.90,147.27,143.67,139.04\left(\mathrm{~d}, J_{C F}=9.9 \mathrm{~Hz}\right), 132.99,131.76,130.16$, 126.77, 126.05, 118.06 (d, $\left.J_{C F}=3.5 \mathrm{~Hz}\right), 117.31$ (d, $\left.J_{C F}=19 \mathrm{~Hz}\right), 109.73\left(\mathrm{~d}, J_{C F}=26.3 \mathrm{~Hz}\right.$ ), 73.15, 67.20, 58.31, 53.47, 52.87, 46.77, 44.12, 33.05, 30.73, 29.79; HRMS (ESI) m/z 535.2222 [calcd for $\mathrm{C}_{25} \mathrm{H}_{33} \mathrm{ClFN}_{6} \mathrm{O}_{4}(\mathrm{M}+\mathrm{H})^{+} 535.2236$ ].

Synthesis of 3,6-Substituted Compounds Submitted for Biological Evaluation 


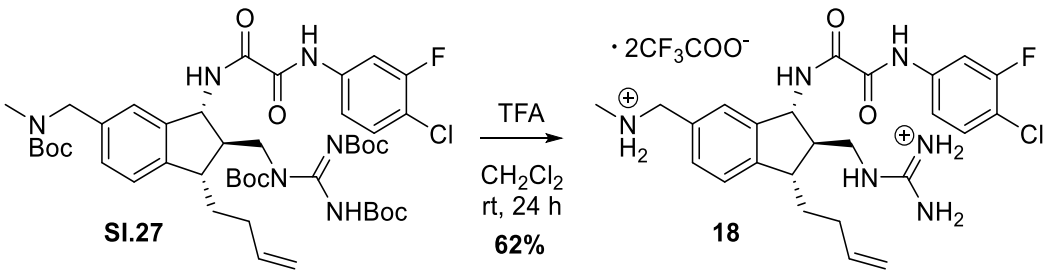

Compound 18 A solution of $\mathrm{SI} .27$ (25 mg, 1.0 equiv.) in $\mathrm{CH}_{2} \mathrm{Cl}_{2}(277 \mu \mathrm{L}, 0.1 \mathrm{M})$ was cooled to 0 ${ }^{\circ} \mathrm{C}$ in an ice-water bath. TFA $(107 \mu \mathrm{L}, 50$ equiv.) was added and the mixture was allowed to warm to rt. Reaction was allowed to stir for 18 hours. The solution was then concentrated in vacuo and the resulting crude residue taken up in $1: 1 \mathrm{CH}_{3} \mathrm{CN}: \mathrm{H}_{2} \mathrm{O}$. The clear solution was purified by HPLC (2 injections of $1000 \mu \mathrm{L}$ each). Eluant: $25: 75$ to $75: 25$ acetonitrile/water (12minute gradient). Flow rate: $15 \mathrm{~mL} / \mathrm{min}$. Product retention time: $7.8-8.0 \mathrm{~min}$. Product fractions were combined, and acetonitrile was removed in vacuo. The resulting aqueous solution was deep-frozen ( $-78 \stackrel{\circ}{\circ}$ bath) and lyophilized $(0.148 \mathrm{mbar})$ to give the bis-trifluoroacetate salt 18 as a white powder (12.5 $\mathrm{mg}, 62 \%)$.

${ }^{1} \mathrm{H}$ NMR (400 MHz, CD $\left.\mathrm{CD}_{3} \mathrm{O}\right) 7.87$ (dd, $\left.J=11.4,2.2 \mathrm{~Hz}, 1 \mathrm{H}\right), 7.52$ (dd, $J=8.9,2.2 \mathrm{~Hz}, 1 \mathrm{H}$ ), $7.49-7.40(\mathrm{~m}, 3 \mathrm{H}), 7.37(\mathrm{~s}, 1 \mathrm{H}), 5.90$ (dddd, $J=16.9,10.2,6.5,6.5 \mathrm{~Hz}, 1 \mathrm{H}), 5.26(\mathrm{~d}, J=7.1$ $\mathrm{Hz}, 1 \mathrm{H}), 5.11-5.06(\mathrm{~m}, 1 \mathrm{H}), 5.02-4.99(\mathrm{~m}, 1 \mathrm{H}), 4.18(\mathrm{~s}, 2 \mathrm{H}), 3.56(\mathrm{dd}, J=13.9,5.4 \mathrm{~Hz}, 1 \mathrm{H})$, 3.49 (dd, $J=14.0,7.1 \mathrm{~Hz}, 1 \mathrm{H}), 3.07(\mathrm{q}, J=6.1 \mathrm{~Hz}, 1 \mathrm{H}), 2.70(\mathrm{~s}, 3 \mathrm{H}), 2.53(\mathrm{p}, J=7.2 \mathrm{~Hz}, 1 \mathrm{H})$, $2.31-2.14(\mathrm{~m}, 2 \mathrm{H}), 2.04-1.89(\mathrm{~m}, 2 \mathrm{H}) ;{ }^{13} \mathrm{C}$ NMR $\left(150 \mathrm{MHz}, \mathrm{CD}_{3} \mathrm{OD}\right) \delta 162.92$ (q, JCF = 35.5 $\mathrm{Hz}, \mathrm{TFA}), 161.83,159.60,159.06\left(\mathrm{~d}, J_{C F}=245.8 \mathrm{~Hz}\right), 158.96,148.02,143.10,139.40,139.04$ $\left(\mathrm{d}, J_{C F}=9.9 \mathrm{~Hz}\right) 131.85,131.75,131.45,126.80,126.12,119.24,118.06\left(\mathrm{~d}, J_{C F}=3.5 \mathrm{~Hz}\right)$, $117.31\left(\mathrm{~d}, J_{C F}=19 \mathrm{~Hz}\right), 115.54,109.70\left(\mathrm{~d}, J_{C F}=26.3 \mathrm{~Hz}\right), 58.39,53.30,53.15,49.57,46.50$, 44.27, 34.20, 32.98, 31.97; HRMS (ESI) $\mathrm{m} / \mathrm{z} 501.2167$ [calcd for $\mathrm{C}_{25} \mathrm{H}_{31} \mathrm{ClFN}_{6} \mathrm{O}_{2}(\mathrm{M}+\mathrm{H})^{+}$ 501.2181].

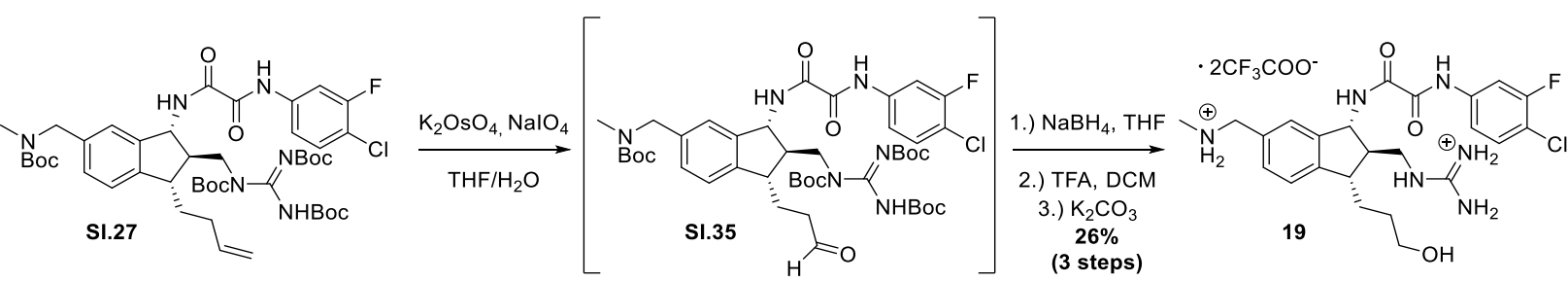

Compound 19 Open to air at rt, $\mathrm{K}_{2} \mathrm{OsO}_{4} \cdot 2 \mathrm{H}_{2} \mathrm{O}(1 \mathrm{mg}, 7 \mathrm{~mol} \%)$ was added in one portion to a stirred solution of SI.27 (100 mg, 1.0 equiv.) in a 4:1 THF: $\mathrm{H}_{2} \mathrm{O}$ mixture (560 $\left.\mu \mathrm{L}, 0.2 \mathrm{M}\right)$. To this mixture was added $\mathrm{NaIO}_{4}(71 \mathrm{mg}, 3.0$ equiv.) in one portion. Reaction was stirred for 4 hours, at which time TLC (30\% EA/hexanes) indicated consumption of starting material. Aqueous saturated $\mathrm{NaHCO}_{3}(1 \mathrm{~mL})$ was added and the aqueous layer was extracted with $\mathrm{Et}_{2} \mathrm{O}(3 \times 1$ $\mathrm{mL}$ ). The organic layers were combined, dried over $\mathrm{Na}_{2} \mathrm{SO}_{4}$, and concentrated in vacuo. The crude residue was then taken up in $\mathrm{EtOH}(1.11 \mathrm{~mL}, 0.1 \mathrm{M})$ and cooled to $0{ }^{\circ} \mathrm{C}$ in an ice-water bath. To this solution, $\mathrm{NaBH}_{4}$ (10 mg, 2.0 equiv.) was added in one portion. The reaction was allowed to stir for 30 mins, at which time $\mathrm{H}_{2} \mathrm{O}(2 \mathrm{~mL})$ was added. The aqueous layer was extracted with EtOAc $(3 \times 2 \mathrm{~mL})$ and the organic layers were combined, dried over $\mathrm{Na}_{2} \mathrm{SO}_{4}$, and concentrated in vacuo. The crude residue was taken up in $\mathrm{CH}_{2} \mathrm{Cl}_{2}(1.1 \mathrm{~mL}, 0.1 \mathrm{M})$ and cooled to $0{ }^{\circ} \mathrm{C}$ in an ice-water bath. TFA (342.1 $\mu \mathrm{L}, 40$ equiv.) was added and the mixture was allowed to warm to rt. The reaction was allowed to stir for 18 hours. To this solution was added solid $\mathrm{K}_{2} \mathrm{CO}_{3}(400 \mathrm{mg})$ and the solution was allowed to stir for 3 additional hours. The solid residue was then filtered and washed with $\mathrm{MeOH}(1 \mathrm{~mL})$. The filtered solution was then concentrated in vacuo and the resulting crude residue taken up in $1: 1 \mathrm{CH}_{3} \mathrm{CN}: \mathrm{H}_{2} \mathrm{O}$. The clear solution was 
purified by HPLC (2 injections of $1000 \mu \mathrm{L}$ each). Eluant: 25:75 to 75:25 acetonitrile/water (12minute gradient). Flow rate: $15 \mathrm{~mL} / \mathrm{min}$. Product retention time: $5.8-6.3 \mathrm{~min}$. Product fractions were combined, and acetonitrile was removed in vacuo. The resulting aqueous solution was deep-frozen $\left(-78{ }^{\circ} \mathrm{C}\right.$ bath) and lyophilized $(0.148 \mathrm{mbar})$ to give the bis-trifluoroacetate salt 19 as a white powder (21.2 $\mathrm{mg}, 26 \%)$.

${ }^{1} \mathrm{H}$ NMR $\left(400 \mathrm{MHz},\left(\mathrm{CD}_{3}\right)_{2} \mathrm{CO}\right) \delta 8.00(\mathrm{dd}, J=11.6,2.4 \mathrm{~Hz}, 1 \mathrm{H}), 7.75-7.72(\mathrm{~m}, 1 \mathrm{H}), 7.54-$ $7.46(\mathrm{~m}, 3 \mathrm{H}), 7.35(\mathrm{~d}, J=7.8 \mathrm{~Hz}, 1 \mathrm{H}), 5.29(\mathrm{~d}, J=7.9 \mathrm{~Hz}, 1 \mathrm{H}), 4.31(\mathrm{~s}, 2 \mathrm{H}), 3.72-3.57(\mathrm{~m}$, $4 \mathrm{H}), 3.18(\mathrm{q}, J=5.7 \mathrm{~Hz}, 1 \mathrm{H}), 2.77(\mathrm{~s}, 3 \mathrm{H}), 2.70-2.63(\mathrm{~m}, 1 \mathrm{H}), 1.96-1.88(\mathrm{~m}, 2 \mathrm{H}), 1.75-1.54$ $(\mathrm{m}, 2 \mathrm{H}) ;{ }^{13} \mathrm{C}$ NMR $\left(100 \mathrm{MHz},\left(\mathrm{CD}_{3}\right)_{2} \mathrm{CO}\right) \delta 159.19,147.51,142.78,139.02\left(\mathrm{~d}, J_{C F}=9.9 \mathrm{~Hz}\right)$ 131.64, 131.50, 131.10, 126.49, 125.37, $117.87\left(\mathrm{~d}, J_{C F}=2.9 \mathrm{~Hz}\right), 116.19\left(\mathrm{~d}, J_{C F}=17.5 \mathrm{~Hz}\right)$, $109.26\left(\mathrm{~d}, J_{C F}=26.0 \mathrm{~Hz}\right) 109.40,62.42,57.92,52.95,52.71,45.57,43.35,32.75,30.59$, 30.53; HRMS (ESI) $\mathrm{m} / \mathrm{z} 505.2145$ [calcd for $\mathrm{C}_{24} \mathrm{H}_{31} \mathrm{CIFN}_{6} \mathrm{O}_{3}(\mathrm{M}+\mathrm{H})^{+} 505.2130$ ].

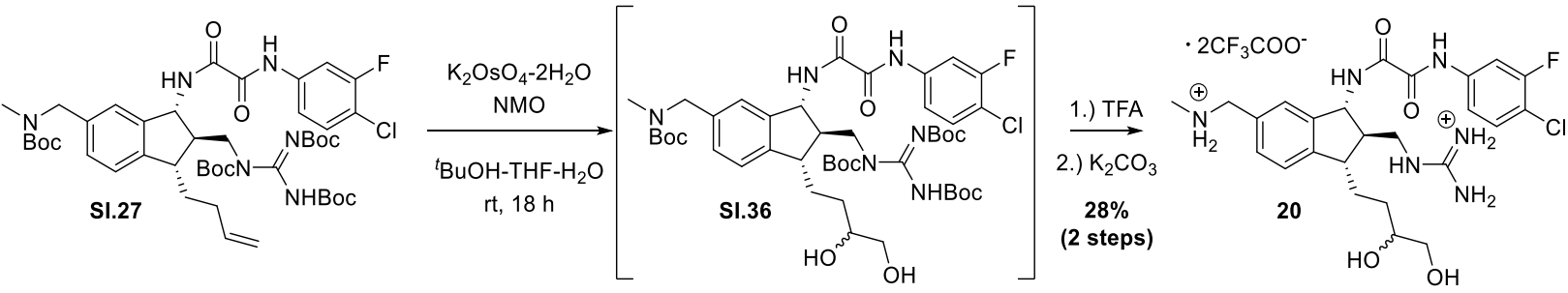

Compound 20 Open to air at rt, $\mathrm{K}_{2} \mathrm{OsO}_{4} \cdot 2 \mathrm{H}_{2} \mathrm{O}(1 \mathrm{mg}, 7 \mathrm{~mol} \%)$ was added in one portion to a stirred solution of $\mathrm{SI} .27$ (24.1 mg, 1.0 equiv.) in a 5:5:1 THF: $\mathrm{BuOH}: \mathrm{H}_{2} \mathrm{O}$ mixture $(900 \mu \mathrm{L}, 0.03$ $\mathrm{M})$. To this mixture was added 4-methylmorpholine $\mathrm{N}$-oxide (4 mg, 1.3 equiv.) in one portion. Reaction was stirred for 20 hours, at which time TLC (30\% EA/hexanes) indicated consumption of starting material. Aqueous saturated $\mathrm{Na}_{2} \mathrm{~S}_{2} \mathrm{O}_{3}(1 \mathrm{~mL})$ was added and the aqueous layer was extracted with $\mathrm{Et}_{2} \mathrm{O}(3 \times 1 \mathrm{~mL})$. The organic layers were combined, dried over $\mathrm{Na}_{2} \mathrm{SO}_{4}$, and concentrated in vacuo. The crude residue was taken up in $\mathrm{CH}_{2} \mathrm{Cl}_{2}(270 \mu \mathrm{L}, 0.1 \mathrm{M})$ and cooled to $0{ }^{\circ} \mathrm{C}$ in an ice-water bath. TFA ( $86 \mu \mathrm{L}, 50$ equiv.) was added and the mixture was allowed to warm to rt. The reaction was allowed to stir for 18 hours. To this solution was added solid $\mathrm{K}_{2} \mathrm{CO}_{3}(100 \mathrm{mg})$ and the solution was allowed to stir for 3 additional hours. The solid residue was then filtered and washed with $\mathrm{MeOH}(1 \mathrm{~mL})$. The filtered solution was then concentrated in vacuo and the resulting crude residue taken up in $1: 1 \mathrm{CH}_{3} \mathrm{CN}: \mathrm{H}_{2} \mathrm{O}$. The clear solution was purified by HPLC (2 injections of $1000 \mu \mathrm{L}$ each). Eluant: 25:75 to 75:25 acetonitrile/water (12minute gradient). Flow rate: $15 \mathrm{~mL} / \mathrm{min}$. Product retention time: $7.5-8 \mathrm{~min}$. Product fractions were combined, and acetonitrile was removed in vacuo. The resulting aqueous solution was deep-frozen $\left(-78^{\circ} \mathrm{C}\right.$ bath) and lyophilized $(0.148 \mathrm{mbar})$ to give the bis-trifluoroacetate salt 20 as a white powder $(5.8 \mathrm{mg}, 28 \%)$.

${ }^{1} \mathrm{H}$ NMR (400 MHz, CD $\left.{ }_{3} \mathrm{OD}\right) \delta 7.87(\mathrm{dd}, J=11.4,2.2 \mathrm{~Hz}, 1 \mathrm{H}), 7.52(\mathrm{dd}, J=8.9,2.2 \mathrm{~Hz}, 1 \mathrm{H})$, $7.48-7.41(\mathrm{~m}, 3 \mathrm{H}), 7.36(\mathrm{~s}, 1 \mathrm{H}), 5.27(\mathrm{~d}, J=7.4 \mathrm{~Hz}, 1 \mathrm{H}), 4.17(\mathrm{~s}, 2 \mathrm{H}), 3.67-3.61(\mathrm{~m}, 1 \mathrm{H})$, $3.60-3.46(\mathrm{~m}, 4 \mathrm{H}), 3.08(\mathrm{p}, J=6.0 \mathrm{~Hz}, 1 \mathrm{H}), 2.69(\mathrm{~s}, 3 \mathrm{H}), 2.57-2.49(\mathrm{~m}, 1 \mathrm{H}), 2.15-2.01(\mathrm{~m}$, $1 \mathrm{H}), 1.96-1.87(\mathrm{~m}, 1 \mathrm{H}), 1.75-1.57(\mathrm{~m}, 1 \mathrm{H}), 1.55-1.39(\mathrm{~m}, 1 \mathrm{H}) ;{ }^{13} \mathbf{C} \mathbf{N M R}\left(150 \mathrm{MHz}, \mathrm{CD}_{3} \mathrm{OD}\right)$ $\delta 162.82\left(\mathrm{q}, J_{C F}=35.5 \mathrm{~Hz}, \mathrm{TFA}\right), 161.84,159.60,159.12\left(\mathrm{~d}, J_{C F}=245.8 \mathrm{~Hz}\right), 158.94,158.34$, 147.91, 147.83, 143.24, 143.16, 139.04 (d, $\left.J_{C F}=9.9 \mathrm{~Hz}\right), 131.80,131.77,131.40,131.39$, 126.67, 126.65, 126.21, 126.12, $118.06\left(\mathrm{~d}, J_{C F}=3.5 \mathrm{~Hz}\right), 117.31\left(\mathrm{~d}, J_{C F}=19 \mathrm{~Hz}\right), 109.75\left(\mathrm{~d}, J_{C F}\right.$ $=26.3 \mathrm{~Hz}$ ), 73.32, 73.19, 67.26, 67.18, 58.37, 53.32, 53.07, 52.88, 46.86, 46.81, 44.24, 44.20, 32.98, 31.12, 30.89, 30.23, 30.07; HRMS (ESI) $\mathrm{m} / \mathrm{z} 535.2231$ [calcd for $\mathrm{C}_{25} \mathrm{H}_{33} \mathrm{ClFN}_{6} \mathrm{O}_{4}(\mathrm{M}+\mathrm{H})^{+}$ 535.2236]. 


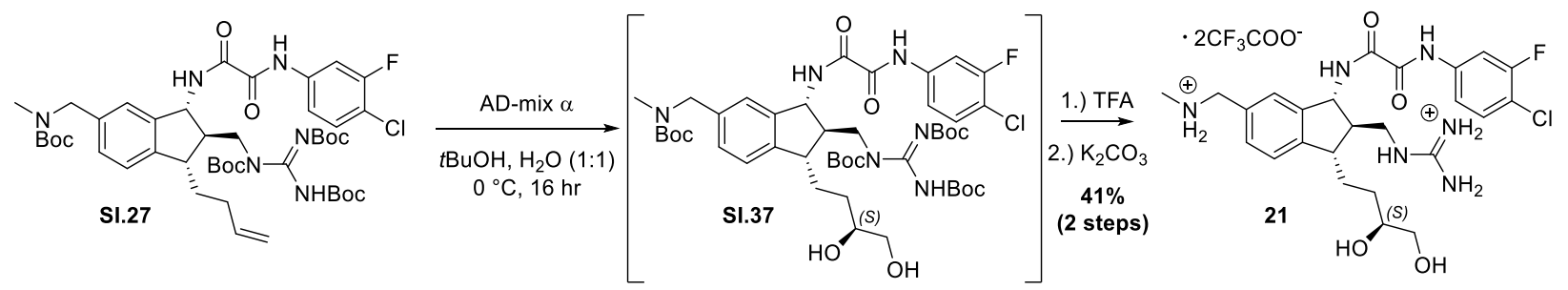

Compound 21 Open to air at rt, AD-mix a (93 mg, 1.4g/mmol substrate) was dissolved in a 1:1 ${ }^{t} \mathrm{BuOH}: \mathrm{H}_{2} \mathrm{O}$ mixture $(670 \mu \mathrm{L}, 0.1 \mathrm{M})$ and was cooled to $0{ }^{\circ} \mathrm{C}$ using an isopropanol bath cooled with a temperature controlled cryostat. To this cooled solution was added SI.27 (50 mg, 1.0 equiv.). Reaction was stirred for 18 hours, at which time TLC (30\% EA/hexanes) indicated consumption of starting material. Aqueous saturated $\mathrm{Na}_{2} \mathrm{~S}_{2} \mathrm{O}_{3}(1 \mathrm{~mL})$ was added and the aqueous layer was extracted with EtOAc $(3 \times 1 \mathrm{~mL})$. The organic layers were combined, dried over $\mathrm{Na}_{2} \mathrm{SO}_{4}$, and concentrated in vacuo. The crude residue was taken up in $\mathrm{CH}_{2} \mathrm{Cl}_{2}(670 \mu \mathrm{L}$, $0.1 \mathrm{M})$ and cooled to $0^{\circ} \mathrm{C}$ in an ice-water bath. TFA (206 $\mu \mathrm{L}, 40$ equiv.) was added and the mixture was allowed to warm to rt. The reaction was allowed to stir for 18 hours. To this solution was added solid $\mathrm{K}_{2} \mathrm{CO}_{3}(250 \mathrm{mg})$ and the solution was allowed to stir for 3 additional hours. The solid residue was then filtered and washed with $\mathrm{MeOH}(2 \mathrm{~mL})$. The filtered solution was then concentrated in vacuo and the resulting crude residue taken up in $1: 1 \mathrm{CH}_{3} \mathrm{CN}: \mathrm{H}_{2} \mathrm{O}$. The clear solution was purified by HPLC (3 injections of $1000 \mu \mathrm{L}$ each). Eluant: 25:75 to 75:25 acetonitrile/water (12-minute gradient). Flow rate: $15 \mathrm{~mL} / \mathrm{min}$. Product retention time: $7.5-8$ min. Product fractions were combined, and acetonitrile was removed in vacuo. The resulting aqueous solution was deep-frozen $\left(-78^{\circ} \mathrm{C}\right.$ bath) and lyophilized $(0.148 \mathrm{mbar})$ to give the bistrifluoroacetate salt 21 as a white powder (21 mg, 41\%). * $>20: 1$ diastereoselectivity observed by ${ }^{1} \mathrm{H}$ NMR post-deprotection.

${ }^{1} \mathrm{H}$ NMR (400 MHz, $\left.\mathrm{CD}_{3} \mathrm{OD}\right) \delta 7.88(\mathrm{dd}, J=11.4,2.2 \mathrm{~Hz}, 1 \mathrm{H}), 7.52(\mathrm{dd}, J=8.9,2.2 \mathrm{~Hz}, 1 \mathrm{H})$, $7.48-7.42(\mathrm{~m}, 3 \mathrm{H}), 7.36(\mathrm{~s}, 1 \mathrm{H}), 5.27(\mathrm{~d}, J=7.5 \mathrm{~Hz}, 1 \mathrm{H}), 4.17(\mathrm{~s}, 2 \mathrm{H}), 3.67-3.55(\mathrm{~m}, 2 \mathrm{H})$, $3.53-3.46(\mathrm{~m}, 3 \mathrm{H}), 3.09(\mathrm{q}, J=5.7 \mathrm{~Hz}, 1 \mathrm{H}), 2.69(\mathrm{~s}, 3 \mathrm{H}), 2.57-2.50(\mathrm{~m}, 1 \mathrm{H}), 2.15-2.03(\mathrm{~m}$, $1 \mathrm{H}), 1.96-1.87(\mathrm{~m}, 1 \mathrm{H}), 1.66-1.57(\mathrm{~m}, 1 \mathrm{H}), 1.55-1.46(\mathrm{~m}, 1 \mathrm{H}) ;{ }^{13} \mathrm{C}$ NMR $\left(150 \mathrm{MHz}, \mathrm{CD}_{3} \mathrm{OD}\right)$ $\delta 162.85\left(\mathrm{q}, J_{C F}=35.5 \mathrm{~Hz}, \mathrm{TFA}\right), 161.84,159.60,159.25\left(\mathrm{~d}, J_{C F}=245.5 \mathrm{f} \mathrm{Hz}\right), 158.93,147.83$, 143.21, $139.04\left(\mathrm{~d}, J_{C F}=9.9 \mathrm{~Hz}\right), 131.80,131.76,131.39,126.66,126.12,118.00\left(\mathrm{~d}, J_{C F}=3.5\right.$ $\mathrm{Hz}), 117.31\left(\mathrm{~d}, J_{C F}=19 \mathrm{~Hz}\right), 109.75\left(\mathrm{~d}, J_{C F}=26.3 \mathrm{~Hz}\right), 73.33,67.26,58.37,53.31,52.88$, 46.81, 44.20, 32.98, 30.91, 30.10; HRMS (ESI) $\mathrm{m} / \mathrm{z} 535.2238$ [calcd for $\mathrm{C}_{25} \mathrm{H}_{33} \mathrm{ClFN}_{6} \mathrm{O}_{4}(\mathrm{M}+\mathrm{H})^{+}$ $535.2236]$. 


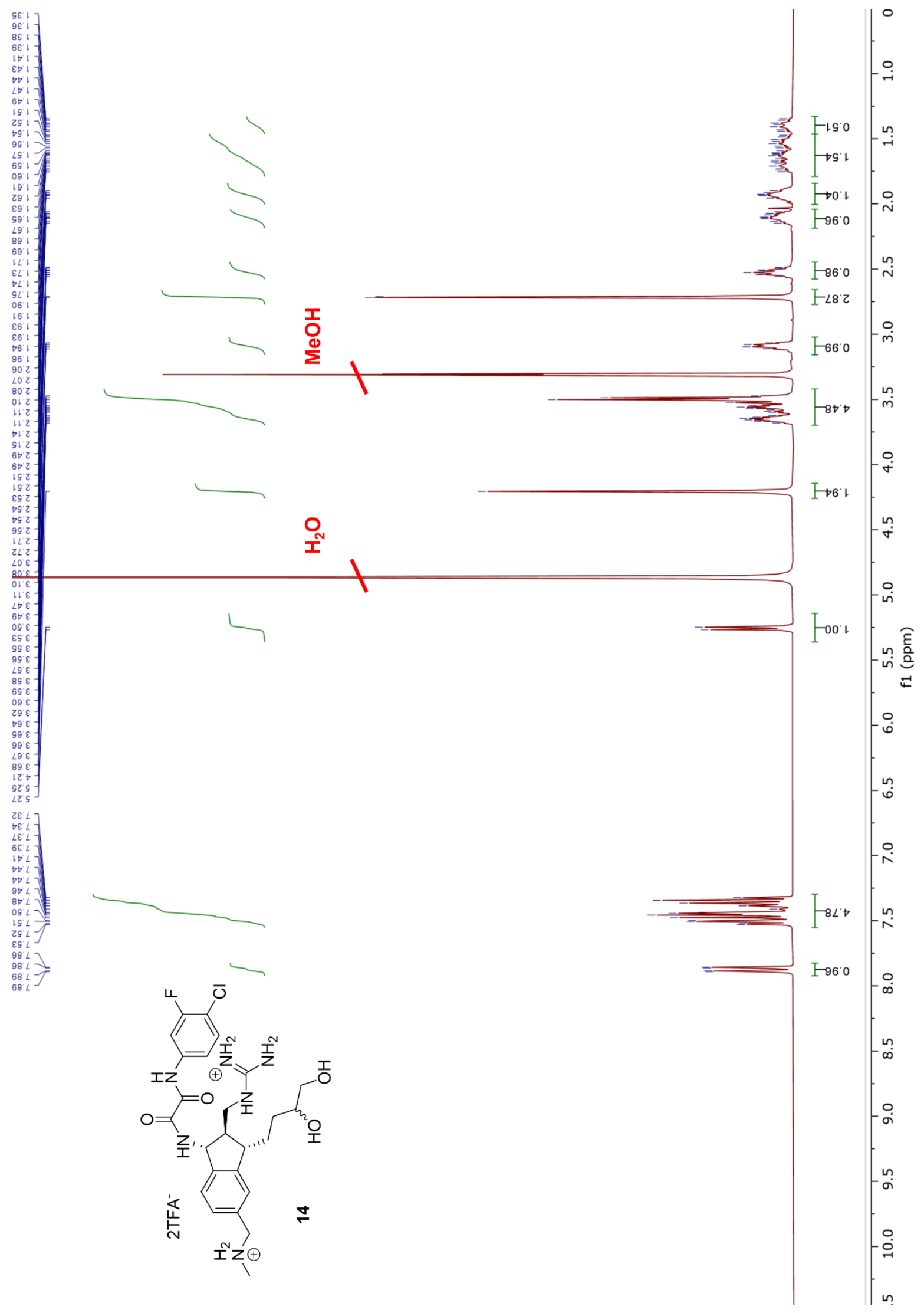




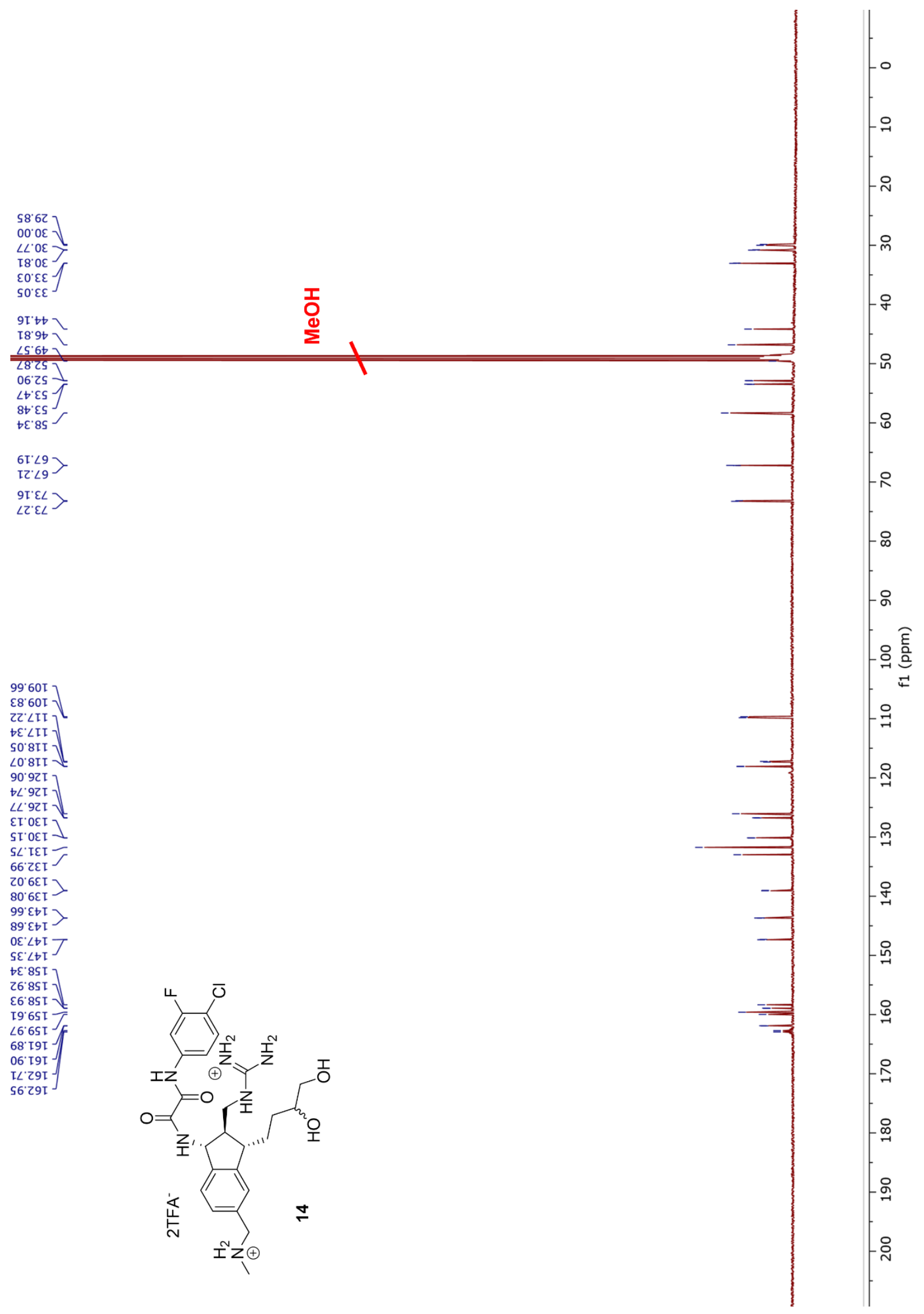




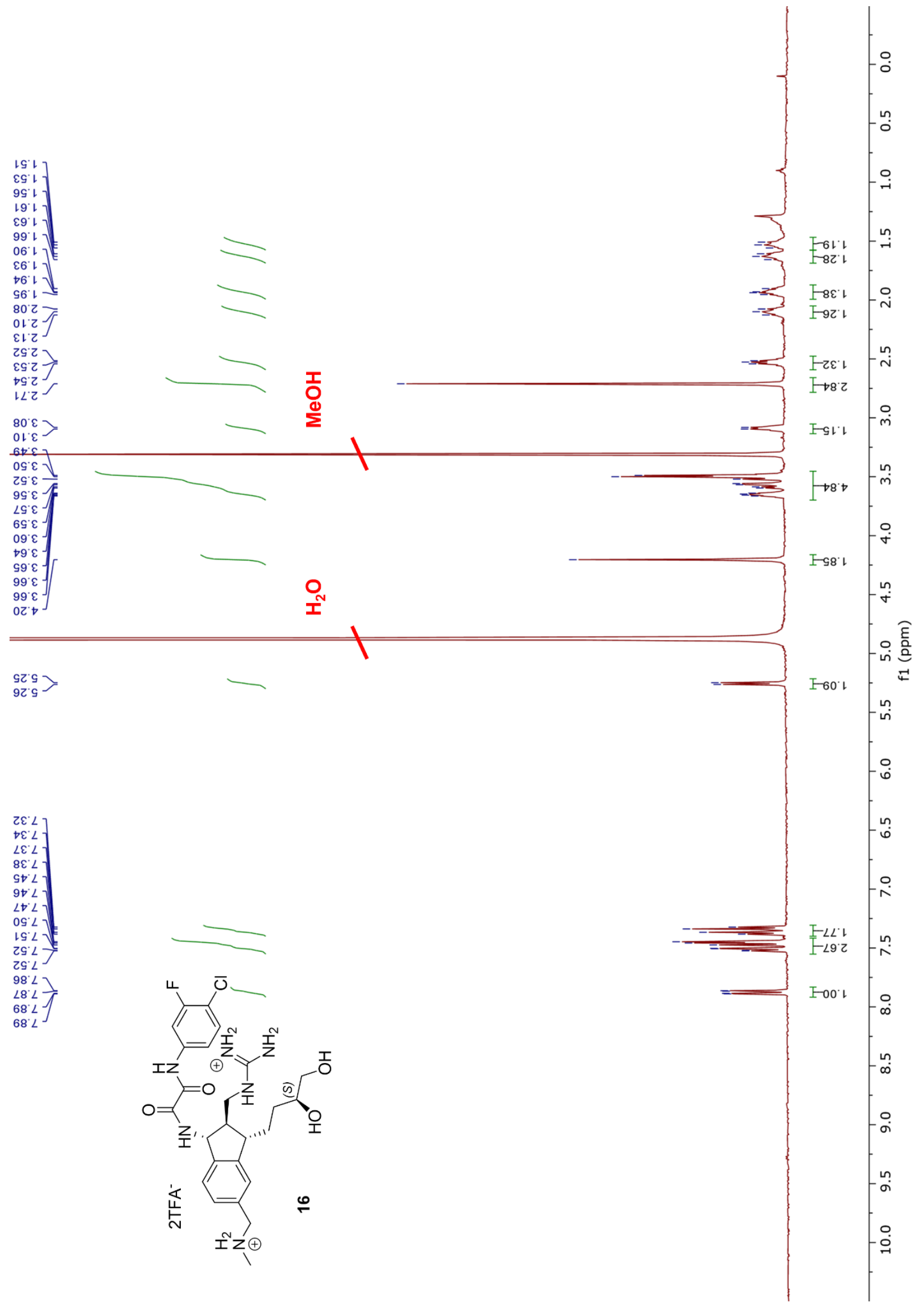




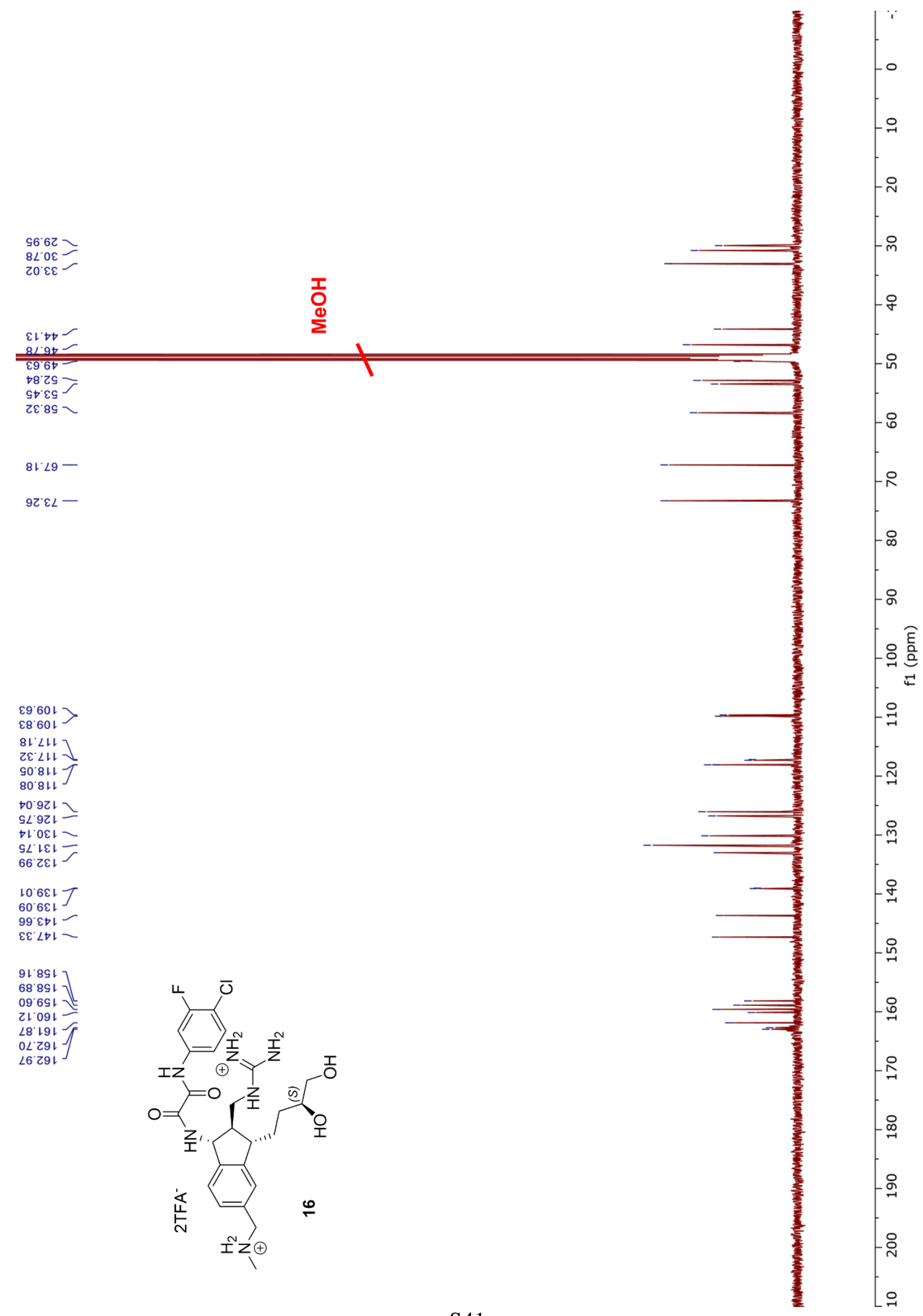




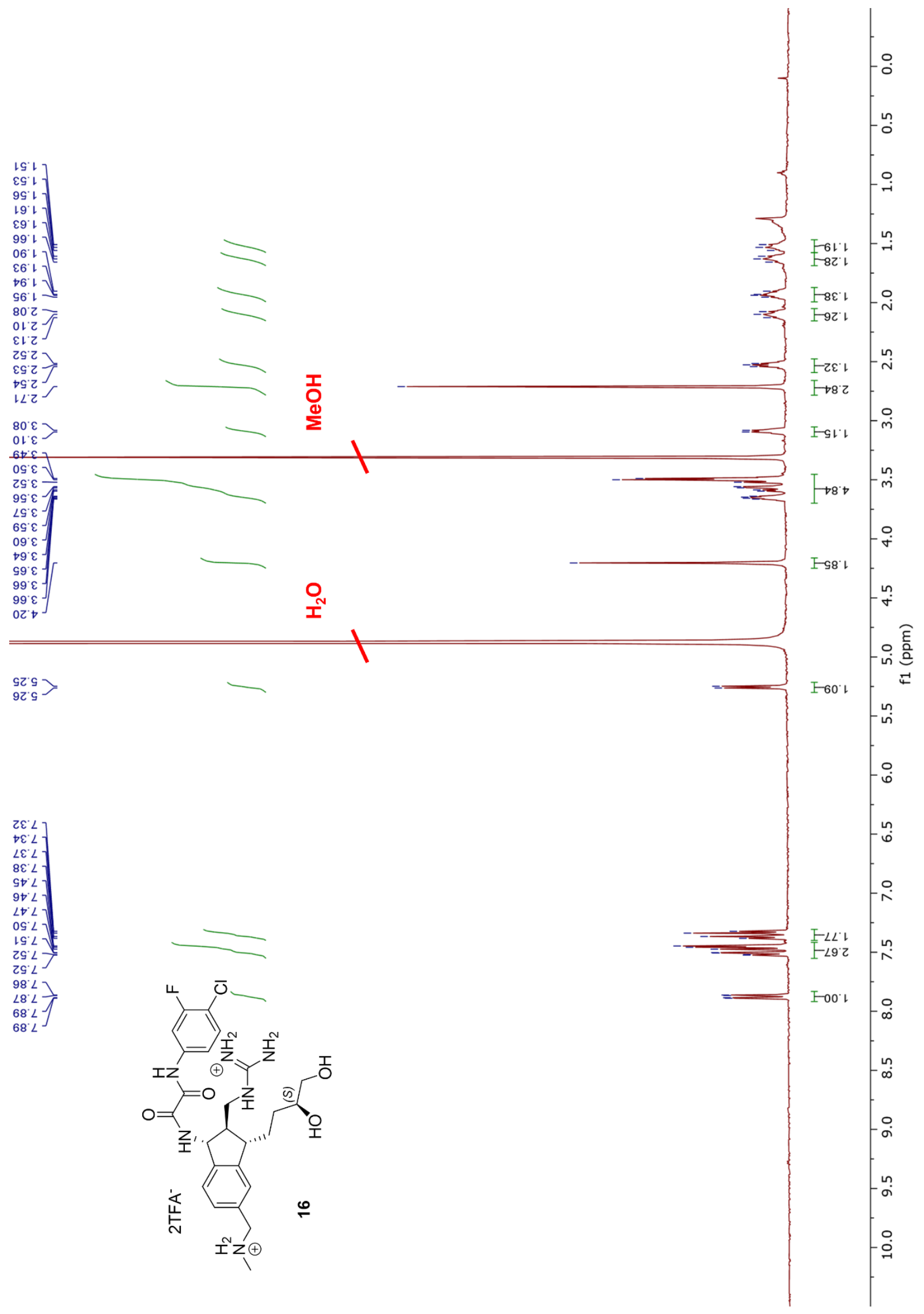




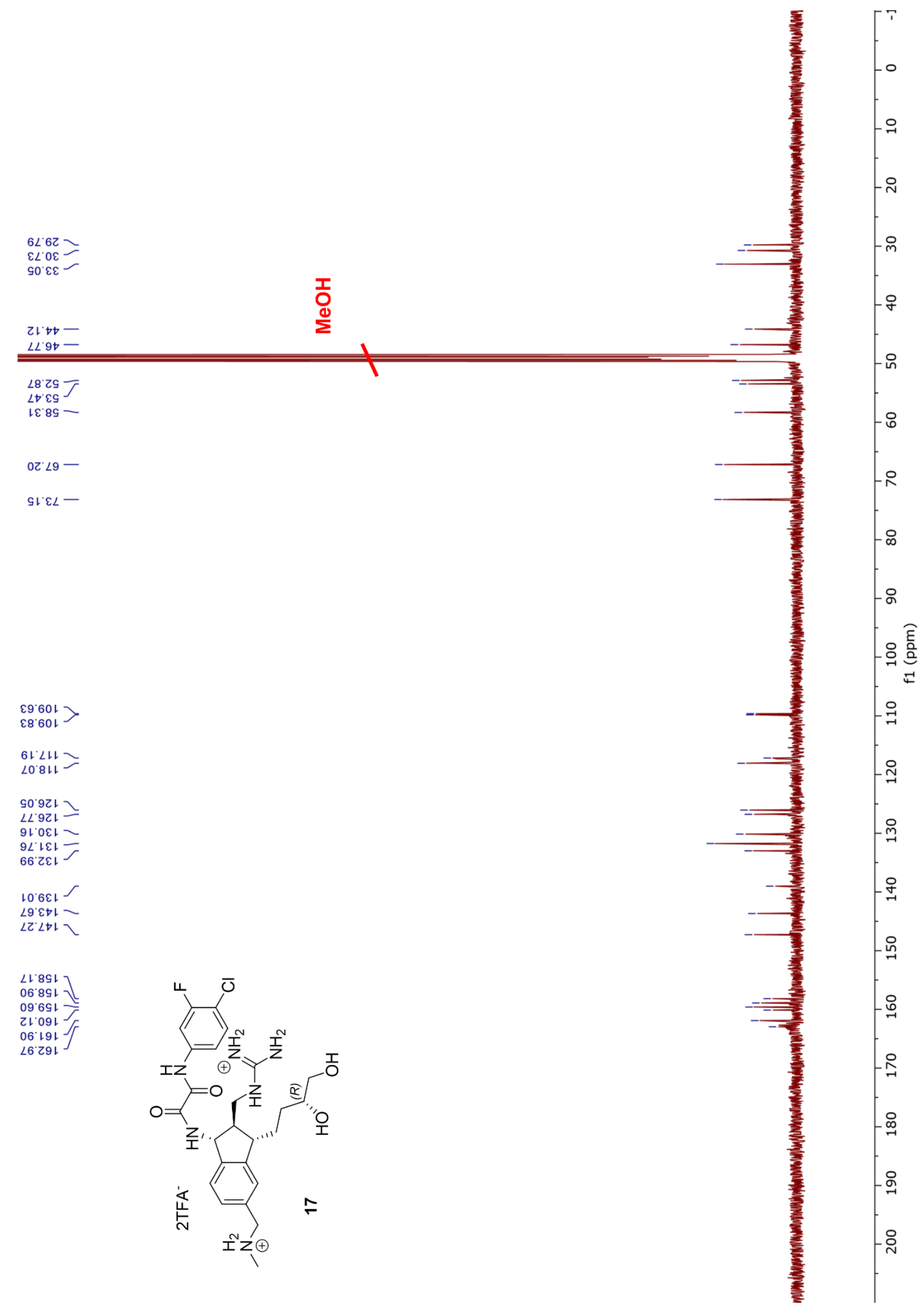

